\title{
Loss of nationality: a critical inventory
}

Citation for published version (APA):

de Groot, G. R. (2003). Loss of nationality: a critical inventory. In D. A. Martin, \& K. Hailbronner (Eds.), Rights and duties of dual nationals (pp. 201-299). Kluwer Law International.

Document status and date:

Published: 01/01/2003

Document Version:

Publisher's PDF, also known as Version of record

\section{Please check the document version of this publication:}

- A submitted manuscript is the version of the article upon submission and before peer-review. There can be important differences between the submitted version and the official published version of record.

People interested in the research are advised to contact the author for the final version of the publication, or visit the DOI to the publisher's website.

- The final author version and the galley proof are versions of the publication after peer review.

- The final published version features the final layout of the paper including the volume, issue and page numbers.

Link to publication

\footnotetext{
General rights rights.

- You may freely distribute the URL identifying the publication in the public portal. please follow below link for the End User Agreement:

www.umlib.nl/taverne-license

Take down policy

If you believe that this document breaches copyright please contact us at:

repository@maastrichtuniversity.nl

providing details and we will investigate your claim.
}

Copyright and moral rights for the publications made accessible in the public portal are retained by the authors and/or other copyright owners and it is a condition of accessing publications that users recognise and abide by the legal requirements associated with these

- Users may download and print one copy of any publication from the public portal for the purpose of private study or research.

- You may not further distribute the material or use it for any profit-making activity or commercial gain

If the publication is distributed under the terms of Article $25 \mathrm{fa}$ of the Dutch Copyright Act, indicated by the "Taverne" license above, 
With the divergent interests of sending and receiving countries, efforts to limit dual nationality will be difficult to realize. ${ }^{10}$ It might be easier to agree on solutions for the specific instances in which interests conflict, like, for example, dual military service or dual taxation.

However, the most effective way to limit dual nationality does not lie in the laws concerning the acquisition of citizenship but those concerning the loss of citizenship. Without a genuine link, persons should lose their citizenship (with the exception of statelessness). This should certainly be the case for second or third generation immigrants born in another country, who have less and less contact with the country of origin of their ancestors. Nevertheless, administrators will have to find a balance between limiting dual nationality and the considerable financial and political costs of enforcing the limits.

\section{Bibliography}

Aleinikoff, Alexander (1998): Between Principles and Politics: The Direction of U.S. Citizenship Policy. Washington, D.C.

Ausländerbeauftragte der Bundesregierung (1997): Daten und Fakten zur Ausländersituation 1995. Bonn.

Ianderbeauftragte der Bundesregierung (1998): Daten und Fakten zur Ausländersituation 1996. Bonn. Ausländerbeauftragte der Bundesregierung (1999): Daten und Fakten zur Ausländersituation
1997. Bonn.

Ausländerbeauftragte der Bundesregierung (2000): Daten und Fakten zur Ausländersituatio 1998. Bonn.

Hagedorn, Heike (1999): Wer soll Deutscher werden? Liberale Trends in der deutschen Einbürgerungspolitik. In: Ulrive Davy ( $\mathrm{Hg}$ ): Politische Integration in ausländischen Eohnbevölkerung. Bade Ulrive Davy ( $\mathrm{Hg}$. Hagedorn, Heike (2000): Wer darf Mitglied werden? Einbürgerung in Deutschland und Frankreich im Vergleich. Opladen.

Münher, Kay und Günter Renner (1991): Staatsangehörigkeitsrecht. Kommentar. München

Spiro, Peter (1998): Embracing Dual Nationality. Occasional Paper No. 1. International Migration Policy Program. Carnegie Endowment for International Peace (Hg.) Washington, D.C.

Thranhardt, Dietrich (1999): Einwandererkulturen und soziales Kapital. Eine komparative Analyse der Zuwanderungsnationalitäten und Bundesländer. Münster.

${ }^{\circ}$ For the positive aspects of dual nationality compare Spiro (1998).

\section{CHAPTER 9}

\section{LOSS OF NATIONALITY: A CRITICAL INVENTORY}

\author{
Gerard-René de Groot
}

The object of this contribution is an inventory of the rules regarding the loss of the Thationaty of a state. Nationality should indicate a genuine link between a state and nation 1 The nationality law of a state therefore provides rules determining under a person. The nationality lo a person who a genuine link with this state. Furthermore, rules are given that is deemed to have a genuine link with this state. Furthernore, res are given that set out the conditions under which the nationality of the state can be acquired, because the person involved has built up a link with this state, which legitimates the possession of the nationality. Finally, the nationality law provides rules on the loss of nationality. In certain cases a person is deemed to have lost his genuine link with a state, while in other cases the state may deprive a person of its nationality because

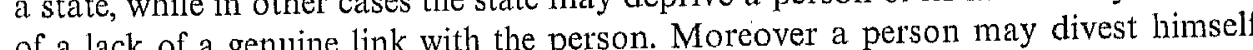
of a lack of a genth a serious link. Most of the nationality of a state with which he no longer hiting loss of nationality nationality legislation also includes rules imposing or permitting loss of nationality because of irregularities during the acquisition of a nationality by naturalization or declaration of option. Some jurisdictions allow deprivation of nationality when
certain manifestions of disloyalty of a person towards his state are discovered.

The rules on the loss of nationality in the various states show a remarkable variety because only a few international documents contain concrete rules on loss of nationality. Art $15(2)$ of the Universal Declaration of Human Rights ${ }^{2}$ states that nobody ity. Art. 15(2) of the Uniticate under which may be deprived arbitrarily of his nationality, but does not indicate under which

Compare the Nottebohm-decision ICJ Reports 1955, 4 (23); Fontes iuris gentium, Series A, sect. 1 Comus 5,81 .

(5e United Nations, UN General Assembly Oflicial Records 3rd Session, Resolutions part 1, 71. Sec on this resolution Marie-Hélène Marescaux, Nationalité et statut personnel dans les instruments des Nations Unies, in Michel Verwilghen, Nationalité et statut personnel, Brussels 1984, 18-24.

Davitd A. Martin all Kay Hailbromner (els.), Rights and Duties of Dual Nationals, 201-299 2003 KL 
circumstances one has to conclude that there is an arbitrary withdrawal of a nationality. The same paragraph of the Universal Declaration guarantees the right of a person to change his nationality, but it is not indicated under which conditions, and must therefore also be qualified as a rather vague rule. The 1957 Convention on the Nationality of Married Women ${ }^{3}$ set forth some rules in respect of non-loss of nationality by marriage or as a consequence of being married: ${ }^{4}$ the sole fact of marriage shall not cause loss of nationality, and loss of nationality by the husband ce lege the loss of nationality by his wife obligations, which have consequences for the regulation of the grounds of loss, exis in the 1961 Convention on the Reduction of Statelessness. ${ }^{5}$ In some cases loss, of nationality is forbidden if the consequence would be statelessness. In Europe the 1963 Convention on the Reduction of Cases of Multiple Nationality and Military Obligations in Cases of Multiple Nationality ${ }^{6}$ is still influential. It prescribes voluntary acquisition of a nationality as a ground for loss of the previous nationality between the contracting states. In many jurisdictions the influence of these international rules can be observed. But conpand to ruls extent inspired by the above mentioned rules, one can find many provisions which are shaped by national experiences and policies.

A very important development in nationality law, in particular for the grounds of loss, is the 1997 European Convention on Nationality ${ }^{7}$ (ECN), which came into force on 1 March 2000. Art. 7 and 8 of that Convention give for the first time in an international legal document, an exhaustive list of acceptable grounds for loss:

Article 7-Loss of nationality ex lege or at the initiative of a State Party

1. A State Party may not provide in its internal law for the loss of its nationality ex lege or at the initiative of the State Party except in the following cases:

a. voluntary acquisition of another nationality;

b. acquisition of the nationality of the State Party by means of fraudulent conduct, false information or concealment of any relevant fact attributable to the applicant;

c. voluntary service in a foreign military force;

d. conduct seriously prejudicial to the vital interests of the State Party;

3 Concluded in New York on 20 February 1957, UNTS vol. 309, 65.

4 Compare as well art. 8-11 of the Hague Convention on Nationality of 12 April 1930, UNTS vol. 179 , 89 and art. 9(1) and (2) of the New York Convention Nationality of 12 April 1930, UNTS vol. 179 89 and art. $9(1)$ and $(2)$ of the New York Convention on the Elimi Concluded in New York on 30 August 1961, UNTS vol. 989,175 .

Initiated by the Council of Europe and concluded in Strasbourg on 6 May 1963, UNTS vol. 634, 221; ETS 43.

Also initiated by the Council of Europe and concluded in Strasbourg on 6 November 1997, Trb. 1998, 10; ETS 166. e. lack of a genuine link between the State Party and a national habitually residing abroad;

where it is established during the minority of a child that the preconditions laid down by internal law which led to the ex lege acquisition of the nationality of the State Party are no longer fulfilled;

adoption of a child if the child acquires or possesses the foreign nationality of one or both of the adopting parents.

2. A State Party may provide for the loss of its nationality by children whose parents lose that nationality except in cases covered by sub-paragraphs $c$ and $d$ of paragraph 1. However, children shall not lose that nationality if one of their parents retains it.

3. A State Party may not provide in its internal law for the loss of its nationality under paragraphs 1 and 2 of this article if the person concerned would thereby become stateless, with the exception of the cases mentioned in paragraph 1, subparagraph $b$, of this article.

Article 8 - Loss of nationality at the initiative of the individual

1. Each State Party shall permit the renunciation of its nationality provided the persons concerned do not thereby become stateless.

. However, a State Party may provide in its internal law that renunciation may be effected only by nationals who are habitually resident abroad.

In this paper the list of art. 7 and 8 will be used as tertium comparationis for the analysis and comparison of the different grounds of loss of nationality in the various analysis and comparison of the lifs nationality will be described and analyzed in jurisdictions. The grounds of loss of nationality will be describs. Furthermore, an the order of the previously mentioned provisions of the ECN. Furthermore, an attempt will be made to evaluate which grounds for loss of nationality conform with the rules of the ECN and which provisions do not. Nevertheless, the ECN is not used as a kind of gospel for nationality law matters. Critical remarks will be offered on some of the rules of the ECN. The tertium valutationis ${ }^{8}$ of these critical remarks on some of the is the question whether, in certain cass that can be classified as a genuine link.

the state of his nationality still exists that can be classified as a genuine link.
A justification of the choice of jurisdictions included in this study is necessary. In light of the fact that this paper is prepared in the framework of the German-USMexican-Turkish research project on problems of multiple nationality, the jurisdictions of the US, Mexico and Turkey are included. Furthermore, next to Germany, all jurisdictions of the European Economic Area are included in order to give a good overview of the attitude of this part of Europe. In this paper the jurisdictions

8 On the distinction between tertium comparationis and tertium valutationis, see Gcrard-René de Groot/ Hildegard Schneider, Das Werturteil in der Rechtsvergleichung, Die Suche nach dem besseren Rech, in: Comparability and Evaluation, Feestbundel Kokkini-Iatridou, "s Gravenhage 1994, 53-68. 
of Moldova ${ }^{9}$ and Canada will be included as well. ${ }^{10}$ Furthermore, some remarks on Polish nationality law will be made. Moldova has already ratified the ECN. The provisions of loss of nationality of this country therefore give some profile to the list provided by art. 7 and 8 of the ECN. In Poland the ratification process of the ECN is in preparation and a whole new bill on Polish nationality is pending in parliament. ${ }^{11}$ In Canada, the House of Commons passed a new act with respect to Canadian citizenship on 30 May $2000^{12}$ The bill is now pending in the Candian Cand the ECN and it is expected that Canada will ratify this convention. ${ }^{14}$

In this paper references to the legislation of the different jurisdictions will be given in a highly abbreviated form. For example " $15(1)($ b) NL" means "art. 15, paragraph 1, lit. b of the Nationality Act of the Netherlands." To indicate the nationality legislation of the different countries, the following abbreviations are used: $\mathrm{A}=$ Austria; $\mathrm{B}=$ Belgium; $\mathrm{C}=$ Canada; $\mathrm{DK}=$ Denmark; $\mathrm{FIN}=$ Finland; $\mathrm{FR}=$ France; $\mathrm{G}=$ Germany; $\quad \mathrm{GR}=$ Greece; $\quad \mathrm{IC}=$ Iceland; $\quad \mathrm{IRL}=$ Ireland; $\mathrm{I}=\mathrm{Italy} ; \mathrm{L}=$ Luxembourg; $\mathrm{MEX}=$ Mexico; $\mathrm{MOL}=$ Moldova; $\mathrm{NL}=$ Netherlands; $\mathrm{N}=$ Norway; $\mathrm{P}=$ Portugal; $\mathrm{POL}=$ Poland; $\mathrm{SP}=\mathrm{Spain} ; \mathrm{SW}=\mathrm{Sweden} ; \mathrm{SWIT}=\mathrm{Switzerland} ; \mathrm{T}=$ Turkey; UK = United Kingdom; USA = United States of America.

Detailed data on the nationality legislation in force in these countries are given in Annex 1. In the footnotes references are occasionally made to older nationality statutes of the mentioned countries. In those cases the paper provides only the number of a provision and the year of enactment of the statute involved. A list of treaties with provisions of relevance for nationality law is given in Annex 2; for each one it is indicated which countries included in the research for this article have ratified the trealy involved. Reservations relevant for the grounds of loss are mentioned. Other reservations and declarations are omitted.

In respect of each ground of loss, a schedule of the regulations of the different countries is provided in order to enable the reader to get a quick first impression of the various solutions and details.

9 In Moldova, a new Nationality Act was adopted on 2 June 2000 and promulgated in the Official Gazette ("Monitorul Oficial") Nr. 98-101 709 of 10 August 2000. I used a trilingual edition published by Alexandru Ohotnicov. The English translation was prepared by Veaceslav Musleata.

Regreltably the jurisdiction of Slovakia could not be included, because no reliable information on the

it recent modificettion of the Slovakian nationality act (affter Slovakia ratified the ECN) could be found. cused an English translation (by Marcin Pruss) of the bill in the version pending in the Sejm in June 2000.

See http:/www.parl.gc.ca/36/2/parlbus/chambus/house/bills/summaries/c16-e.htm (last visited on Although one has

Although one has to realize that, due to the parliamentary elections of November 2000, the bill has 14 to pass both chambers of parliament again.

European States, paper delivered on the Ist of the European Convention on Nationality for Non19 October 1999 .

\section{VOLUNTARY ACQUISITION OF A FOREIGN NATIONALITY ${ }^{15}$}

\section{A. General Remarks: Treaties}

The first ground for loss of a nationality allowed by art. $7 \mathrm{ECN}$ is the voluntary The acquistion of this ground for loss. In respect of this ground for loss, art. 7(2) of the provisions on this grounduction of Statelessness of 1961 underlines that this loss is Convention on the Reduction of Statelessness of 1961 underlines acceptable if the foreign nationality is really acquired. The application for a foreign nationality should not automatically cause the loss. It provides:

A national of a Contracting State who seeks naturalization in a foreign country shall not lose his nationality unless he acquires or has been accorded assurance of acquiring the nationality of that foreign country.

Voluntary acquisition is the core rule of the Convention on Reduction of Cases of Multiple Nationality and Military Obligations in Cases of Mulitiple Nationality of 1963. art. 1(1) of that Convention stipulates:

Nationals of the Contracting Parties who are of full age and who acquire of their own free will, by means of naturalization, option or recovery, the nationality of another Party shall lose their former nationality. They shall not be authorised to retain their former nationality.

Nevertheless in 1993 a Second Protocol ${ }^{16}$ to the 1963 Convention was opened for signature, allowing exceptions to be made to the main principle of art. 1 of the 1963 Convention. Under the Protocol, voluntary acquisition of a foreign nationality does not necessarily cause the loss of the previous nationality if: a national "acquires the

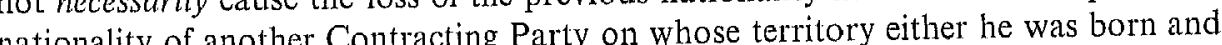
hationality of another Contime beginning before the is resident, or has been ordinatily resident for a per will the nationality of the other age of 18;" a spouse "acquires of his or her own free will the nationality of the other
spouse;" or a minor "whose parents are nationals of different Contracting Parties acquires the nationality of one of his parents."

Three contracting states of the 1963 Convention have ratified this Second Protocol in the past few years: France, Italy, and the Netherlands. ${ }^{17}$ Between these countries, art 1 of the 1963 Convention is no longer operative for the categories mentioned in

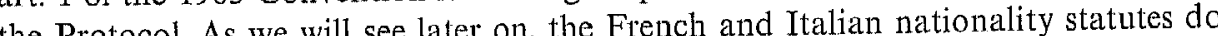
the Protocol. As we will see lasition of a foreign nationality as a ground for loss of not mention voluntary acquisition of a foreign nationality as a Therefore, French and Italian nationals belonging to the categories

is Compare Gerard-René de Groot, Staatangehörigkeitsrecht im Wandel, Köln 1989, 282-287.

16 Compare Gerard-Rene de 1993 in Strasbourg, ETS 149; Trb. 1994, 265.

17 Italy ratified the Second Protocol on 27 January 1995, France, on 23 February 1995, and the Netherlands, on 19 July 1996. The Second Protocol came into force between the first two states onc month after the second ratification, i.e., on 24 March 1995. The Netherlands is bound by the Protoco since 20 August 1996. See Tractatenblad 1994, 265 and 1996, 201. 
mentioned in the Second Protocol may acquire the nationality of another country which ratified the Second Protocol without losing their original nationality. Nationals of the Netherlands still lose their previous nationality when acquiring the nationality of France or Italy even if they belong to the privileged categories of the Second Protocol, because the Netherlands has not yet modified its domestic nationality legislation. However, a bill proposing to adapt the nationality legislation to the rules of the Second Protocol is pending in parliament. ${ }^{18}$

\section{B. Loss}

The nationality legislation of a considerable number of countries provides that voluntary acquisition of a foreign nationality may cause the loss of the nationality of the country involved. Some countries always provide for loss if a foreign nationality is acquired voluntarily, without making any exceptions. An example is art. 15(a) NL according to which a person who is of full age ${ }^{19}$ shall lose his Netherlands nationality by acquiring another nationality of his own free will. ${ }^{20}$

Similar provisions can still be found in all Scandinavian countries: 7(1) DK, $8(1)$ FIN, 7(1) IC, 7(1) N, 7(1) SW. The same applies for Belgium: $22(1)(1)$ and $(2)^{21}$ and Luxembourg: 25(1) L. In the Netherlands ${ }^{22}$ and in Sweden, ${ }^{23}$ proposals to respectively modify and repeal the above mentioned provisions are pending in parliament.

In this context art. 37(B)(I) MEX has to be mentioned as well, where voluntary acquisition of a foreign nationality is mentioned as grounds for ex lege loss of Mexican nationality, but since 20 March 1997, the provision only applies to naturalized Mexicans. ${ }^{24}$ Previously, voluntary acquisition of a foreign nationality was a general ground for loss of Mexican nationality. ${ }^{25}$ The restriction of this ground for loss to naturalized citizens conflicts with art. 5(2) ECN, where it is stressed that each state party shall be guided by the principle of non-discrimination between its nationals, whether they are nationals by birth or have acquired its nationality subsequently. ${ }^{26}$

18 Bill 25891 (R 1609) has already been accepted by the Chamber of Representatives ("Tweede Kamer") and is scheduled for debate in the Senate for December 2000.

This is a person who has attained the age of eighteen or has married before attaining that age; see

Art. 7(1) and (3) Act 1892 and - for naturalization - art. 9(1) Civil Code 1838 and art. 10(1) Act 1850. See art. 17(1) Code Civil 1804; art. 11(1) Act 1909; art. 18(1) Act 1932. Belgium provided, from 1926 until 1991, an exception for those Belgians, who still were subject to military obligation

Bill 25891 (R 1609)

Bill $1999 / 2000: 147$, sent to parliament on 8 June 2000

In force since 20 March 1998. See Carlos Arellano Garcia, Derecho internacional privado, 13th edition,

26 Compare 19(1)(e) IRL, where deprivation of the Jationality of a naturalized Irish citizen is possible, if they voluntarily acquire a foreign nationality.
C. Loss: Exceptions

Several countries provide in principle for ex lege loss of nationality by voluntary acquisition of a foreign nationality, but make some exceptions:

(a) The person involved was granted the right to retain the nationality before acquiring the second

This is for example the case in Austria, where the conditions for permission to maintain the nationality in case of acquisition of a foreign nationality are listed in par. 28A:

1. the maintenance of Austrian nationality has to be in the interest of Austria due to the achievements ("Leistungen") of the applicant in the past or to be expected in the future or due reasons, which have to be especially taken into account;

2. the foreign country whose nationality the person involved wishes to acquire 2. the foreign country whose nationality the person involved wishevided for under consents to the maintenance of
international agreements; and

3. the conditions under par. $10(1)(2-4,6 \text { and } 8)^{27}$ are met, i.e. no criminal record, no danger for public policy or security in Austria, no relations with foreign States which could harm the interests or reputation of Austria.

If the conditions listed in par. 28 are met, an applicant has the right to receive permission to retain Austrian nationality although he voluntarily acquires anothe nationality. However, the first condition gives the Austrian authorities wide discretion. It he to be stred that permission is only granted if an interest of the Austrian Republic requires it to do so. A special interest of the individual to retain Austrian Republic requires it to do so.
nationality is not sufficient. ${ }^{28}$

In Germany par. 25(2) provides for the possibility of written consent from the German authorities to retain citizenship in certain cases of voluntary acquisition of a foreign nationality. Since 1 January 2000 , par. $25(2)(2) \mathrm{G}$ states that the decision regarding an application for permission to retain nationality must take into account public and private interests. ("Die berührten öffentlichen und privaten Belange sind (the applicant has his habitual gegenenander und untere residence abroad, attention has to be paid to whether conthous ties with Germany are likely ("ob er fortbestehende Bindungen an Deutschland glaubhaft machen

27 Par. $10 \mathrm{~A}$ deals with the conditions for naturalization.

essler, Osterreichisches Staatsbürgerschaftsrecht, 4th edition, Vienna 1996, 1988, 1499 and Verwaltungsgerichtshof 4. April 1990, Zeitschrift für Verwaltung 1991, 677. Sec also

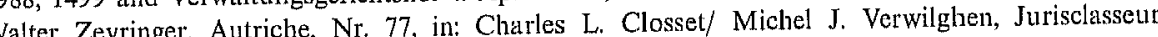
Nationalité, Paris, looseleaf edition.

29 For more detail see Allgemeine Verwaltungsvorschrift zum Staatsangehorigkeitsrecht ( $\mathrm{StAR}-\mathrm{VwV}$ ) of 18 October 2000, comments on par. 25. Compare as well the paper of Rey Koslowski, Challenges of International Cooperation in a World of Increasing Dual Nationality, this volume. 
kann"). Before 1 January 2000, the consent stated in par. 25(2) was not often granted. ${ }^{30}$ In the future it will be considerably easier to acquire this consent.

An obvious difference between the Austrian and German provisions is that in Austria consent to retain Austrian nationality is given only because of a specific interest of the state, whereas in Germany the interest of the individual involved can also provide a reason for giving permission. It should be noted that both countries ratified the 1963 Convention on the Reduction of Cases of Multiple Nationality and in respect of the right to allow any of its nationals to retain their previous nationality in case of voluntary acquisition of a foreign nationality.

(b) The person involved still has to fulfill his military obligations

This exception was the case in Belgium until 1991. Art. 22(2) B (old) provided that a person who has reached the age of eighteen years and is subject to military service obligations ("qui est encore soumis aux obligations du service militaire pour l'armée active et sa réserve") needed the authorization of the King in order to lose Belgian nationality by voluntary acquisition of a foreign nationality. This condition was introduced into Belgian law in 1926 and abolished by the act which allowed the ratification of the 1963 Convention, because it did not conform with the aim and purpose of that Convention, ${ }^{31}$ Furthermore, the condition was to become obsolete because Belgium abolished mandatory military service. ${ }^{32}$ Finally, the consent involved was, in practice, always granted. ${ }^{33}$

(c) The person involved does not live abroad, but still lives within the country See, for example, Spain art. 24(1), according to which persons of full age ("emancipados") who have their habitual residence abroad lose Spanish nationality if they voluntarily acquire another nationality or exclusively use the other nationality, which was attributed ${ }^{34}$ to them before they reached full age (emancipation). $A$ contrario, we can conclude that a Spanish national living in Spain does not lose his nationality by voluntary acquisition of another nationality.

Until 1 January 2000, the German nationality act also provided that a German living in Germany would not lose his nationality by voluntary acquisition of a

30 Kay Hailbronner/ Günter Renner / Christine Kreuzer, Staatsangehorigkeitsrecht München 1998, 2nd edition, comments 28-36 on par. 25 RuStAG; Fritz Sturm, Allemagne, Nr. 122, in: Charles L. Closset/ on the application of on the application of par. 25 (2) do not exist; information given by telephone by the German Ministry of Internal Affairs on 8 November 2000.

Act of 22 May 1991, Moniteur belge 1991, 15.109, in force since 16 July 1991.

1992, in force since 1994

34 See Charles-Louis Closset, Traité de la Nationalité Belge, Bruxelles 1993, 377 with further references. The Spanish text uses the word "atribuida", which is - if I read it correctly - more narrow than the English expression "acquired, because it cloes not include cases where the person involved acquired the nationality by declaration of option or by naturalization. foreign nationality, but this provision (25(1) $\mathrm{G}$ (old)) was abolished. Until Italy abolished voluntary acquisition of a foreign nationality as a ground for loss in 1992, Italy also provided for an exception in case of residence in the country (art. 8(1), Act 1912).

(d) The acquisition of certain specified foreign nationalities

This exception is of paramount importance in Spain. Art. 24(2)(2) SP ${ }^{35}$ provides that the acquisition of the nationality of Latin-American countries, Andorra, Philippines, Equatorial Guinea or Portugal is not enough for the loss of the Spanish nationality of origin. ${ }^{36}$ Bill 122/000003 submitted by the "Grupo Parlamentario Socialista" to the Spanish parliament on 24 April 2000 proposes to add the nationalities of the Member States of the European Union to this list. Although it is very uncertain whether this proposal will be accepted, it is interesting to note this attention to the special ties of the Member States of the European Union with each other. The restriction of the exception made by art. 24(2)(2) to Spanish nationals by origin ("españoles de origin") excludes naturalized Spanish nationals from the exception and therefore violates art. 5(2) ECN.

(e) In case of war

An example is art. 24(4) SP, which provides that Spanish nationality is not lost if Spain is at war.

(f) The exceptions made by the 1993 Second Protocol to the 1963 Convention

These exceptions, mentioned previously, may apply for the states which ratified this Protocol (France, Italy, and the Netherlands), if a national acquires the nationality of another contracting state. In the Netherlands, bill 25891 (R 1609) proposes to make several exceptions to the general rule that voluntary acquisition of a foreign nationality causes the loss of Netherlands nationality, inspired by the Second Protocol of the 1963 Strasbourg Convention. The proposed new art. 15 prescribes Protocol of the 1963 Stasbous Convention. The propaly is still lost by voluntary - as far as is revant here - that Netherlonds acquisition of a foreign nationalty, but that this ground for loss does not apply if the national involved a) was born in the foreign country whose nationality he acquires and has his habitual residence in that country; b) was living as a minor during a continuous period of at least five years in the country whose nationality he wants to acquire; or c) acquires the nationality of a spouse or registered partner. ${ }^{37}$ It has to be stressed that nearly all the previously mentioned exceptions are It has to be

36 In accordance with art. 11(3) of the Spanish Constitution. In this context it has to be mentioned that Spain concluded trealiss countries on double nationaity allowing the voluntary acquisition of the nationality of a contracting
state without losing the original nationality. See Juan Aznar Madrid 1977.

37 See on the institution of "registered partner" the thorough comparative report of Caroline Forder prepared for the 5th Family Law Conference of the Council of Europe, 15th/16th March 1999. 
allowed by art. 7(1)(a) ECN, because this article allows voluntary acquisition of a foreign nationality to serve as a general ground for loss, but does not oblige Member States to provide for any ground of loss listed in art. 7. What is problemetic, in view of art. 5(2) ECN, are the Mexican and Spanish provisions, because of the different, and in my opinion discriminatory, treatment of nationals of origin and naturalized citizens.

\section{No Loss}

In contrast, a considerable number of countries do not include voluntary acquisition of a foreign nationality as a ground for loss of their nationality. For example, art. 11 I stresses that the citizen who possesses, acquires, or regains a foreign citizenship shall keep the Italian one. Precisely because of the fact that voluntary acquisition of a foreign nationality does not in principle have consequences for the possession of Italian nationality, it is remarkable that art. 24 I obliges an Italian citizen, who acquires, regains, or chooses a foreign citizenship, to communicate this to the registrar of the place of residence or, if he resides abroad, to the competent consular authority within three months from the acquisition, recovery or option. If he does not fulfill this obligation, he is subject to a fine of between 200,000 and 2,000,000 Lire. This provision can be understood if one realizes that Italy is still a contracting state of the 1963 Convention. Furthermore, in the very special situation of war, loss of Italian nationality because of voluntary acquisition of another nationality is still possible.

Italy abolished voluntary acquisition of a foreign nationality as a ground for loss in $1992 .{ }^{38}$ France (since 1973) ${ }^{39}$ Ireland, Portugal (since 1981) ${ }^{40}$ Switzerland, ${ }^{41}$ the United Kingdom (since 1949), ${ }^{42}$ and Canada (since 1977) also do not list voluntary acquisition of a foreign nationality as a ground for loss. In Sweden bill $1999 / 2000: 147^{43}$ proposes to abolish voluntary acquisition of a foreign nationality as a ground for loss of Swedish nationality completely. Poland did abolish voluntary acquisition of a foreign nationality as a ground for loss of nationality in 1951, as

38 Act of 5 February 1992, Nr. 91, Gazetta Ufficiale 15 February 1992, Nr. 38.

39 France is still a contracting state of the 1963 Convention and of the 1993 Second Protocol. In case of voluntary acquisition of the nationality of another contracting state, French nationality can be lost. In case of voluntary acquisition of a foreign nationality, France allows renunciation of French nationa-

40 See Rui Manuel Moura Ramos Do Direito Português dact to military service obligations.

the grounds why Portugat abolised voluntary acquistion loss and abolished other grounds for loss as well- Since 1981 Portugucse nutionality as a ground for by renunciation by the person involved

Switzerland never provided for loss of

nationality.

From 1870-1949 voluntary acquisition of a foreign nationality was a ground for loss of British nationality, although between 1870-1914 a declaration of retention was allowed. See sec. 6 Act 1870

43 Sent 13 Act 1914 did all the former socialist countries in Middle and Eastern Europe. ${ }^{44}$ The bill on Polish nationality pending in parliament does not propose to reintroduce this ground for loss.

\section{E. No Loss: Exceptions}

Some of these countries, however, make exceptions in particular cases:

(a) In case of war

Art. 12(c) I provides that an Italian citizen shall lose his Italian nationality when the state of war ceases if, during the state of war against a foreign state, he voluntarily acquired the nationality of this state. This Italian provision is a remarkable contrast to the Spanish rule, which specifies that Spanish nationality is in principle lost by voluntary acquisition of a foreign nationality, but inter alia not if Spain is at war.

\section{(b) For naturalized citizens}

It was already mentioned above that voluntary acquisition of a foreign nationality is, for a naturalized Mexican citizen, a ground for loss of Mexican nationality ex lege (37(B)(I) MEX). In Ireland sec. 19(1)(e) IR states that:

The Minister may revoke a certificate of naturalization if he is satisfied ... (e) that the person to whom it is granted has by any voluntary act other than marriage acquired another citizenship.

It has to be stressed again that both the Mexican and the Irish rule conflict with the principle of art. 5(2) ECN.

\section{(c) Because of art. 1 of the 1963 Convention on the Reduction of Cases of Multiple} Nationality

Art. 1 of that Convention operates automatically and therefore prevails above the domestic nationality law of a contracting state. Although the domestic nationality law of France and Italy abolished voluntary acquisition of a foreign nationality as a ground for loss, these countries did not denounce the 1963 Convention. If a national voluntarily acquires the nationality of another contracting state to the 1963 Convention, the origial nationality is lost except in cases where the Second Protocol to the 1963 Convention allows an exception to be made (both France and Italy to the 1963 Convention allows an exception to
ratified the Convention, as did the Netherlands). ${ }^{45}$

44 Albania (1946), Bulgaria (1948), German Democratic Republic (1949), Hungary (1957), Yugoslavia (1945), Romania (1948), Czechoslovakia (1949). See on this issue Matjaz Tratnik, Het nationaliteit recht in de Oosteuropese landen, Deventer 1989, passim.

45 In Sweden bill 1999/2000:147. which aims to abolish voluntary acquisition of a foreign nationality as a ground for loss of Swedish nationality also proposes the denunciation by Sweden of the 1963 Convention. 


\section{F. Special Solutions}

A different approach can be observed in the Greek and Turkish nationality legislation. Voluntary acquisition of a foreign nationality is never a ground for loss ex lege of Greek or Turkish nationality, but a voluntary acquisition of a foreign nationality without previous permission of the government may be a reason for deprivation of nationality: see 20 (1) $\mathrm{GR}^{46}$ and $25(\mathrm{~A})$ (a) $\mathrm{T},{ }^{47}$ In both countries the authorities have a certain power of discretion. Nevertheless, in Turkey, art. 25(A)(a) is quite frequently used as a basis for deprivation of Turkish nationality. ${ }^{48}$ On the application of the corresponding Greek provision, no information was available to me.

Compare also for Greece art. 14(1) and (3) GR. Every Greek citizen who acquires a foreign nationality voluntarily may apply for special permission to surrender his or her Greek nationality. A similar rule applies if a Greek citizen accepts public service in another country, if this acceptance results in the acquisition of the citizenship of that country. In exceptional cases, permission to acquire the foreign nationality may be granted after the acquisition of the foreign citizenship. In that case the loss of the Greek nationality occurs at the moment that permission is oranted Permission has to be granted by the Minister of the Interior after having requested the opinion of the council for citizenship. Permission is not granted if the applicant delays his military obligation or is being prosecuted for a crime or offense. In practice, the just mentioned permissions are very rarely granted. ${ }^{49}$

In this context, art. 23(1)(d) MOL has to be mentioned. It provides that the voluntary acquisition of the nationality of another state that has not concluded an agreement on dual citizenship with Moldova can be a ground for deprivation of Moldovan nationality if the person involved does not renounce the foreign nationality (literally: "la cetatenia unuia dintre state" (the citizenship of any of the states)) within one year. Therefore, the loss does not occur ex lege at the moment of the acquisition, but can be the consequence after a period of time. The formulation "may be revoked"

${ }^{46}$ See Marie-Hélène de Brabandere-Marescaux/ Sophia Koukoulis-Spiliotopoulos, Grèce, Nr. 93, 94, 102-104, in: Charles L. Closset/ Michel J. Verwighen, Jurisclasseur Nationalité, Paris, looseleaf edition. See on the Turkish permission procedure, Nuray Eksi, Political Rights of Dual Nationals in Turkish Law, this volume. Compare also the paper of Christian Rumpl, Citizenship and Multiple Citizenship

in Turkish Law, this volume, and Vedat R. Sevig, Turquie, Nr. 79-83,

18 The statistics on application of Art 25(A)(a) are as follows:

1990: 1381 persons; 1991: 711 persons; 1992: 504 persons; 1993: 96 persons; 1994: 93 persons; 1995: 828 persous; 1996: 180 persons; 1997: 95 persons; 1998: 96 persons; 1999: 30 persons; 2000: 42 Directorate of Civil Status and Natdonallin Karahocag_l, Turkish Interior Ministry (The General of 23 Oetober 2000). The provision was used, inter alia, in the cose of Depar(ment) in an e-mail member of Parliament who became controversial because she case Merve Kavakci, the elected the National Assembly. She was later found to have acquired US. citizenship through opening of shortly before her election. See Eksi, this volume.

49 Until 1914, Greece provided for loss ex lege in case of voluntary acquisition of a foreign nationality. See Anastasia Grammaticaki-Alexiou, in: Nascimbene, 399; Zoe Papassiopi-Passia The Greek Nationality Law in a Nutshell, Revue Hellénique de Droit International 1998, 511-512. ("poate fi retrasa") indicates that the President of Moldova has a margin of appreciation.

A very particular stance is taken by the United States. Sec. $349^{50}$ Immigration and Nationality Act (INA) provides that:

(a) A person who is a national of the United States whether by birth or naturalization, shall lose his nationality by voluntarily performing any of the following acts with the intention of relinquishing United States nationality -

(1) obtaining naturalization in a foreign state upon his own application or upon an application filed by a duly authorized agent, after having attained the age of eighteen years;

(b) Whenever the loss of United States nationality is put in issue in any action or proceeding commenced on or after the enactment of this subsection under, or or proceeding commenced on or after the enactment the provisions of this Act or any other Act, the burden shall be upon the person or party claiming that such loss occurred, to establish such claim by a preponderance of the evidence. Any person who commits or performs, or who has committed or performed, any act of expatriation under the provisions of this or any other Act shall be presumed to have done so voluntarily, but such presumption may be rebutted upon a showing, by a preponderance of the evidence, that the may be rebutted upon a showing, by a preponderance of the
act or acts committed or performed were not done voluntarily.

At first sight voluntary acquisition of a foreign nationality seems to be a clear ground for loss of U.S citizenship. Until the 1960s, the former version of sec. 349(a)(1) INA was applied in that manner. But the decisions of the U.S. Supreme 349(a)(1) INA was applied in that manner. But the decisions of the U.S. Supreme
Court in Afroyim v. Rusk ${ }^{51}$ and Vance v. Terrazas ${ }^{52}$ held that the U.S. Constitution Court in Afroyim v. Rusk ${ }^{51}$ and Vance v. Terrazas ${ }^{22}$ held that the U.S. Constitution permits loss of citizenship (except for fraudulent or illegal nationality) only if the The U.S. Congress amended the law thereafter to include the requirement of the intent to relinquish US nationality. This requirement applies to all the expatriating acts liste in 349 (like forign military service or taking an oath or making an (1ke foregn affirmation or other formal declaration of allegiance to a foreign state or a political
subdivision thereof $)^{53}$

G. Some Difficulties

In those countries where voluntary acquisition can be a ground for loss of the Fis "voluntary" In cases where the che determined precisely what

$\begin{array}{ll}\text { s0 } & 8 \text { U.S.C. } \$ 1481 . \\ 51 & 387 \text { U.S. } 253(1908)\end{array}$

$52 \quad 444$ US. 252 (1980). See Alfred del Rey, Jr, États-Unis d’Amérique, in: Charles L. Closset/ Michel J. Verwilghen, Jurisciasseur Nationalité, Paris, looseleaf edition, Nr. 106, 108, 109.

See T. Alexander Aleinikoff, Theories of Loss of Citizenship, Michigan Law Review 1986 (vol. 84) $1471-1503$ 
nationality involved was acquired without any application and without any possibitity to avoid the acquisition, the provisions in question certainly do not apply. In cases of obvious coercion they also do not apply. But are the provisions applicable in cases where a national acquired another nationality, because he was more or less forced to apply for the foreign nationality because of political or economic circumstances? The answer is yes in, for example, Belgium, Germany, and the Netherlands, but is no in Spain.

A related question is whether voluntary "acquisition" also covers cases where the foreign nationality is acquired ex lege but could be rejected. In the Netherlands the answer is affirmative, ${ }^{54}$ in some other countries like Austria, ${ }^{55}$ Belgium, ${ }^{56}$ and Germany, ${ }^{57}$ the answer is negative.

Again, slightly different are cases where the nationality is acquired by accepting a public office in another country without the possibility to avoid this acquisition (for example by accepting an appointment as professor at an Austrian university (see art 25(1) A). The Netherlands nowadays does not consider Auch acquisition (ses voluntary, but in the past another interpretation was defended and applied by the Ministry of Justice. ${ }^{58}$ It has to be mentioned in this context that the Scandinavian countries have a special provision dealing with this type of acquisition (e.g., art. $7 \mathrm{DK}$ ) and thereby obviously show that in their opinion this type of acquisition is not covered by their general provision on loss of their nationality by voluntary acquisition of a foreign nationality. Austria also considers this type of acquisition of a foreign nationality as not voluntary. ${ }^{59}$

\section{H. Trends}

Studying the nationality legislation of the different states mentioned before; one can observe a certain tendency to abolish voluntary acquisition as a ground for loss: UK (1949), FR (1973), Portugal (1981), Italy (1992), Sweden (proposal 2000). These countries accept that a person may have such close ties with more than one country that the possession of more than one nationality is justified. Because of this acceptance of multiple nationality, the question arises whether the voluntary acquisition of a foreign nationality always indicates that the genuine link with the state of one's

s4 Compare in this context art. 6 Ley de nacionalidad mex:: "un acto juridico para obtenerla o conservarla" (An act to acquire or to keep a foreign nationality) and art. 25 (7) L.

${ }_{56}$ Zeyringer, Nr. 73

Nationalité, Paris, et, Belgique, Nr. 149, in: Charles L. Closset/ Michel J. Verwilghen, Jurisclasseur Nationalité, Paris, looseleaf edition. In the sume Nr., Closset underscores that the other nationality British protected persons or British subjects 7 British protected persons or British subjects)

ss Algemeine Verwaitungsvorschrilt zum Staatsangehörigkeitsrecht of 18 October 2000, Nr. 25.1.3. See, agalinst the previous interpretation, Gerard-René de Groot, Wijziging van het Oostenrijkse Zeyringer, Nr. 73, with refere original nationality ceases immediately. ${ }^{60}$ In the end, the countries involved answered this question in the negative. The view of these countries is acceptable. But one must stress that it must be compensated by the possibility, given to an individual who stress that it must be compensated by the possibility, given to an individual who
acquires another nationality, to renounce his old nationality. Otherwise one could acquires another nationality, to renounce his old nationality. Otherwise one could
be confronted with cases of perpetual allegiance, which conflicts with art. 15 of the be confronted with cases of perpetual allegiance, which conflicts with art. 15 of the on renunciation of nationality).

We saw furthermore that some countries did not abolish voluntary acquisition as a general ground for loss of their nationality, but introduced (or are introducing) exceptions to the main rule. An example is the bill pending in parliament in the exceptions to the main rule. An example is the bill pending in parliament in the
Netherlands proposing exceptions inspired by the 1993 Protocol to the 1963 Netherlands proposing exceptions inspired by the 1993 Protocol to the 1963 Convention. The proposal pending in the Spanish parliament to add the Member acquired without losing Spanish nationality also has to be mentioned in this context. Another example is the fact that after 1 January 2000, Germany will give consent to retain German nationality in case of voluntary acquisition of a foreign nationality retain German nationality in cases than in the past.

Last but not least, a certain tendency to interpret "voluntary acquisition" very strictly can be observed. The decisions of the courts of the United States and of Mexico are remarkable in this respect. But one can refer as well to a surprising interpretation of art. 24(2) S: Spanish nationality is lost after a period of three years from the acquisition of the foreign nationality, but no loss of Spanish nationality happens if Spanish nationality is still used. ${ }^{61}$

II. REVOCATION OF NATURALIZATION DECREE OR OF ACQUISITION BY OR CONCEALMENT OF ANY MATERIAL FACT ATTRIBUTABLE TO THE OR CONCEALMENT OF ANY MATERIAL FAC
APPLICANT

\section{A. General Remarks: Treaties}

Art. 7(1)(b) ECN provides for the deprivation of nationality by revocation of a Art. $7(1)$ (b) ECN provides for the deprivation of nationality by revacation of a false information, or concealment of any material fact attributable to the naturalized national, even if the consequence would be statelessness (see art. 7(3) ECN).

60 Compare my suggestion to provide that voluntary accuisition should be maintained as a ground fo loss of nationality, but a dechrotion of retention should be possible, which has to be renewed at least every 10 years. See Gerard-René de Groot, Staatsangehörigkeitsrecht, 284-286.

61 See José Carlos Fernández Rozas/Aurelia Alvarez Rodriguez, Le droit espagnol de la nationalité, in Bruno Nascimbene (ed.), Nationality Laws in the European Union, Milano 1996, 234, 235. Compare also the very remarkable exception made on this ground for loss before 1990; no loss occurred in case of an acquisition for reasons of emigration ("por razón de emigración"). 
A similar provision could already be found in art. 8 of the 1961 Convention on the Reduction of Statelessness:

1. A Contracting State shall not deprive a person of its nationality if such deprivation would render him stateless.

2. Notwithstanding the provisions of paragraph 1 of this Article, a person may be deprived of the nationality of a Contracting State:

b. ... where the nationality has been obtained by misrepresentation or fraud.

B. Fraud, False Information, or Concealment of any Material Fact

Several countries expressly provide in their nationality legislation that fraud or concealment in respect of the acquisition of nationality may be a reason for revocation of the acquisition.

An example is sec. 40(1) UK, which applies to any British citizen who became a British citizen by registration or by naturalization:

Subject to the provisions of this section, the Secretary of State may by order deprive any British citizen to whom this subsection applies of his British citizenship if the Secretary of State is satisfied that the registration or certificate of naturalisation by virtue of which he is such a citizen was obtained by means of fraud, false representation or the concealment of any material fact.

Sec. 40 contains precise procedural rules which have to be observed when the Secretary of State wants to use the possibility of subsection 1 . There is an appeal to a committee of inquiry. Sec. 40(1) has only rarely been used.62 since 1951 only 10 persons have been deprived of citizenship and in only two cases on the ground of false representation. No one has been deprived of citizenship under this section since 1973. ${ }^{63}$ What is remarkable is that persons who told significant lies as to their identity are deemed never to have been granted certificates of naturalization at all. Therefore their possession of British nationality is revoked without paying attention to the formalities of sec. $40 .^{64}$

A very similar provision can be found in Ireland (19(1))

The Minister [for Justice] may revoke a certificate of naturalisation if he is satisfied

(a) that the issue of the certificate was procured by fraud, misrepresentation,

62 Nicholas Blake, British Nationality Law, in: Bruno Nascimbene (ed.), Nationality Laws in the European Union, Milano 1996, 708.

63 Information given by Andrew Hirst, Police Section of the Immigration and Nationality Directorate of the Home Office in a letter of 7 September 2000

64 See Nicholas Blake, in Nascimbene, 706, with reference to Nahcem Ejaz v. Secretary of State 3 December 1993 CA; R. v. Secretary of State ex p. Parvaz Ahktar, 1981 QB 46 CA. whether innocent or fraudulent, or concealment of material facts or circumstances, ...65

See also 17(2) IRL

If any person, for the purposes of or in relation to an application for a certificate of naturalisation, gives or makes to the Minister any statement or information which is to his knowledge false or misleading in any material respect, he shall be guilty of an offence and shall be liable on summary conviction to a fine not exceeding five hundred pounds or, at the discretion of the court, to imprisonment for any term not exceeding six months or to both such fine and imprisonment.

Comparable rules can be found in several other jurisdictions. In France the subdirection of naturalization investigates about 300 suspect naturalization files each year. For a withdrawal of nationality the consent of the Council of State (Conseil d'Etat) is required. In 1998 only 29 files were submitted to the Council of State, and the Council consented to withdrawal in 16 cases. The number of withdrawals is the Council consented to withdrawal in 16 cases. The number of withdrawals is decreasing over the last few years. In 1996, 51 withdrawals took place and in 1997
46 cases ${ }^{66}$ In Luxembourg the public prosecutor can initiate a procedure leading to 46 cases. $^{66}$ In Luxembourg the public prosecutor can initiate a procedure leading to
the withdrawal of nationality if it was acquired by false information, fraud, or concealment of important facts ("par de fausses affirmations, par fraude ou par dissimulation de faits importants") (27(a) L). ${ }^{67}$

In Moldova art. 23(1)(a) allows the deprivation of nationality because of the fact Thaldovan nationality was acquired by fraud, false information, or concealment of any relevant fact if this is proved by the court.

The new Polish bill on nationality regulates the revocation of a naturalization decree (and other decisions concerning the acquisition of Polish nationality) in art. 10. A revocation is possible if 1 ) documents, on the basis of which the crucial factual assessment took place, had been forged, or 2) the decision resulted from a criminal act, or 3) new factual circumstances or new evidence, which existed at the time the decision was taken, became available but were not known to the authority that issued the decision. If 10 years have passed since the day on which the decision was issued the decision. If 10 years have passed since the day on which the decibser
issued, a revocation or annulment of the decision is no longer possible.

In Spain it is possible that the nationality is withdrawn by a sentence which declares that the person involved has obtained Spanish nationality by means of false representation, concealment of any fact, or fraud. This withdrawal does not influence the rights of third persons acquired in good faith. The nullity procedure is only

$6 s$ Philipe de Patoul/ Tony O'Connor/ John G. Fish, Irlande, Nr. 74, in: in: Charles L. Closset/ Michel J. Verwilghen, Jurisclasseur Nationalité, Paris, looseleaf edition, mention in 1984, that since 1956 no revocation of a naturalization decree has taken place. Furthermore, these authors stress that it is very dubious whether this ground for loss is in conformity with the Irish constitution.

66 Information received from Paul Lagarde, mail of 14 January 2001.

67 Statistical data on the application of this provision are not available, but the deprivation of Luxembourg nationality on this ground is very rare. Information provided by M. A. Ketter, Ministry of Justice in a letter of 28 September 2000 . 
possible within 15 years of the acquisition of Spanish nationality (25(2) SP). In the Spanish legal literature it is stressed that fraud, etc. is not a ground for loss, but a ground for nullity of the acquisition. ${ }^{68}$

In Switzerland an annulment of a naturalization because of false information or concealment of relevant facts ("falsche Angaben oder Verheimlichung erheblicher Tatsachen") is exclusively possible within five years of the acquisition (41(1) SWIT). ${ }^{69}$ This provision has its roots in art. 2 of the Decree (Bundesratsbeschluß) of 11 November 1941. According to that Decree, the revocation had to take place within 10 years from the acquisition and was also possible because of an obvious un-Swiss attitude ("offenkundig unschweizerische Gesinnung").

Also according to art. 24 TURK, revocation of a naturalization decree by the Council of Ministers is possible if it is discovered that during the naturalization procedure false documents were submitted or important information was concealed. A revocation is no longer possible more than five years after the naturalization of the person involved. This provision is rarely used. ${ }^{70}$

A very detailed regulation of revocation of naturalization because of concealment of a material fact or willful misrepresentation, without any limitation in time, can be found in the United States in sec. $340 \mathrm{INA}^{71}$

(a) It shall be the duty of the United States attorneys for the respective districts, upon affidavit showing good cause therefor, to institute proceedings in any district court of the United States in the judicial district in which the naturalized citizen may reside at the time of bringing suit, for the purpose of revoking and setting aside the order admitting such person to citizenship and canceling the certificate of naturalization on the ground that such order and certificate of naturalization were illegally procured or were procured by concealment of a material fact or by willful misrepresentation, and such revocation and cetting as of the orch admitting such person to citizenship and such canceling order admitting such person to citizenship and such canceling of certificate of naturalization shall be effective as of the original date of the order and certificate, respectively....

(b) The party to whom was granted the naturalization alleged to have been illegally procured or procured by concealment of a material fact or by willful misrepresentation shall, in any such proceedings under subsection (a) of this section, have sixty days' personal notice, unless waived by such party, in which

${ }_{68}$ See for example Aurelia Alvarez Rodriguez, Guía de la nacionalidad española, 2nd edition, Madrid See for example Aurelia
$1996,92,93$, note 146 .

69 According to Roland Schärer, Swiss Nationality Section, mail of 15 January 2001, art. 41 is applied in about 30 cases per year. He mentions also, that these revocations mostly concern facilitated naturalizations on the basis of marringe with a Swiss citizen The revocations occur becouse of fulse declarations on the effectiveness of a mavital community, or because of higamous marriases.

10 According to Sadrettin Karahocagil, Turish Interior Ministry (The General Direcol Status and Nationality Issues; Head of Nationality Department) in an e-mail of 23 October 2000 there was just one incident in 1999 .

718 U.S.C. \$ $\$ 451$. to make answer to the petition of the United States; and if such naturalized person be a from the judicial district in which person be absent from the United steres or such person last had his residence, such notice shall be given either by personal service upon him or by publication in the manner provided for the service of summons by publication or upon absentees by the laws of the State or the place where such suit is brought.

(d) Any person who claims United States citizenship through the naturalization of a parent or spouse in whose case there is a revocation and setting aside tion of a parnt or sove provisions of the order admitting stch pant or spouse to citiz the order and certificate of of subsection (a) of this section on the ground that the order and certificate of naturalization were procured by concealment of a material fact or by willful misrepresentation shall be deemed to have lost and to lose his citizenship and any right or privilege of citizenship which he may have, now has, or may hereafter acquire under and by virtue of such naturalization of such parent or spouse, regardless of whether such person is residing within or without the spouse, admitting such parent or spouse to citizenship. ..

(e) When a person shall be convicted under section 1425 of title 18 of the (e) When a person shall be convicted under section 1425 of title 18 of the United States Code of knowingly procuring naturalization in violation of law, the court in which such conviction is had shall thereupon revoke, set aside, and declare the certificate of naturalization of such person to be canceled. ...

(g) The provisions of this section shall apply not only to any naturalization (g) The provisions of this section shall apply not only to any issued under the granted and to certificates of naturalization and citizenship issued under the provisions of this title, but to any naturalization heretofore granted by any court, and to all certificates of naturalization and citizenship which may have been issued heretofore by any court or by the Commissioner based upon naturalization granted by any court, or by a designated the Nationality Act of Como as amer other

(h) Nothing con by in

(h) Nothing contained in this section shall be regarded as limiting, denying, or restricting the power of the Attorney General to correct, reopen, alter, modify, or vacate an order naturalizing the person. ${ }^{72}$

72 Cl. as well sec. 329(c) INA: "Citizenship granted pursuant to this section may be revoked in accordance with section 340 of this title if at any time subsequent to naturalization the person is separated from the military, air, or naval forces under other than honorable conditions, and such ground for revocation shall be in addition to any other provided by law. The fact that the naturalized person was separated from the service under other than honorable conditions shall be proved by a duly authenticated certification from the exccutive department under which the person was serving at the time of separation.". 
In Johannessen $v$. United States $(1912)^{73}$ the Supreme Court decided that the revocation of a naturalization decree because of fraud does not constitute a cruel or excessive measure which is forbidden by the eighth amendment to the Constitution. ${ }^{74}$ In Mexico art. 26 Ley de Nacionalidad of 23 January 1998 provides for the possibility to declare the nullity of a naturalization decree, if this decree was made but not all conditions for a naturalization were fulfilled, or if it was made under violation of the Nationality Act ("cuando se hubiere expedido sin cumplir con requisitos a con violacion a esta ley"). The person involved must be given con opportunity to voice his opinion. The declaration of revocation has to mention the moment from which the naturalization is void ("la fecha a partir de la cual dic carta sera nula"). Rights of third persons acquired in good faith are protected.

Art. 16 of the Canadian bill $\mathrm{C}-16^{75}$ provides for the possibility of a revocation of a naturalization decree,

If the Governor in Council is, on the report of the Minister, satisfied that a person has obtained. ... citizenship by false representation or fraud or knowingly concealing material circumstances.

Procedural rules to be observed are given in secs. 16(2) through 18.

In the Netherlands a ground for loss corresponding with the provision of art. 7(b) ECN is proposed by bill 25891 ( $\mathrm{R} 1609$ ) in art. 14: the acquisition of Netherlands nationality by naturalization or declaration of option can be annulled because of false information, fraud or concealment of any relevant fact by the person involved. The annulment is possible only within a period of 12 years after the acquisition of Netherlands nationality, with the exception of cases where the person involved was sentenced for crimes of war, torture or genocide; in the latter cases revocation is possible without any time limit. Art. 14(4) allows this deprivation even if the consequence would be statelessness. ${ }^{76}$

It is remarkable that several countries do not provide expressly in their nationality act for the possibility of revocation of a nationality decree if fraud etc. is discovered. In some countries, nevertheless, revocation is possible in in application of provisions of general administrative law. That is, for example, the case

73225 U.S. 227; 32 S.Ct. 613.

14 See Alfred del Rey, Nr. 107; furthermore Murad Ferid/Dieter Blumenwitz, Das Staatsangehörigkeitsrecht der Vereinigten Staaten von Nordamerika, Frankfurt am Main 175, 101-109. Th is remarkable that hie state makes not only behavior in the past, but also behavior after are based on joining communist or totalitarian organizations or refusing to testify before concenter hearings on subversive activities. These presumptions, however are relics of the early Cold War yenrs have not been used for decades, and are of doubtful constitutionality.

Compare sec. 10 Citizenship Act.

Critical remarks on this proposal: Gerard-René de Groot, Verder op weg naar een hernieuwd nationalteltsrecht, Bespreking wijzigingsnota Rijkswet Nederlanderschap, Migrantenrecht 1999, $13-22$.

220 in Germany, where revocation of an administrative act because of fraud is possible in Germany, where revocation on art. 48 VwVfG. $^{77}$ The authorities have to undertake steps in order to revoke the naturalization within The authorities have to undertake steps in order to revoke the naturalization within one year after they discovered the fraud (art. $48(4) \mathrm{VwVfG}$ ). In the legal literature it is argued that a revocation can no longer take place five years after the naturalizafor naturalization under a false name can be a ground for revocation of the naturalization decree depends on whether, because of the false identity, other requirements for naturalization are also not fulfilled. ${ }^{80}$ This possibility to revoke a naturalization naturalization are also ${ }_{\text {decree is not often used }}^{81}$

In Austria it is possible to reopen the naturalization procedure on the basis of In Austria it is possible to reopen the naturalization procedure on the basis of par. 69(1) Allgemeines Verwaltungsverfahrensgesetz $z^{82}$ in case of fraud, new facts, new pieces of evidence, or new decisions on relevant preliminary questions. In case would be the consequence. For the other cases par. 24 A determines that reopening is only possible if the revocation would not cause statelessness ${ }^{83}$

In some countries difficulties may arise in respect of revocation, because these In some countries difficulties may arise in respect of revocation, because these countries naturalize foreigners by an Act of Parliament (Belgium, Denmark, and
until 1 October 1998 , Iceland). ${ }^{84}$ Nevertheless, Belgian nationality was revoked in a until 1 October 1998 , Iceland). ${ }^{84}$ Nevertheless, Belgian nationality was revoked in
couple of cases where fraud was discovered. The fraud was classified as a serious neglect of their obligations as a Belgian citizen (art. 23(1) B), therefore as serious prejudicial behavior ${ }^{85} \mathrm{~A}$ special provision for the possibility to revoke a naturalization because of fraud is lacking. ${ }^{86}$

Haibrouner/Renner/Kreuzer, Comment 36,37 on art. 16 GG. See furthermore Sturm, Nr. 109 and M. von Klüchtzner, Probleme der Rücknahme einer Einburgerung, in: Op de grenzen van het Nederlanderschap (Feestbundel Zilverentant), 's Gravenhage 1998, 127-131.

Makarov/ von Mangoldt, Kommentar, art. 16 RuStAG, N. J3. Compan pa. 24 StAngRegG.

VGH Mannheim 9 May 1990, NVwZ 1990, 1198; OVG Nordrhein-Westfalen 2 September 1996, StAZ 1997, 137; cf. BVerwG 13 April 1989, NVwZ -RR 1990, 220.

80 Von Klitchtzner, 131

Von KIChzaner relers to two cases where an applicant for naturalization did not inform the authorities that he was married to two women simultaneously.

Bundesgesetzblatt 1991, 51

Information given by Peter Mak, Bundesministerium fur Inneres in a letter of 1 September 2000. Compare the information of Jón Thors, Dóms- og Kirkjumálar Áduneytid (Ministry of Justice and Ecciesiastical Aftairs), Reykjavik in a letter of

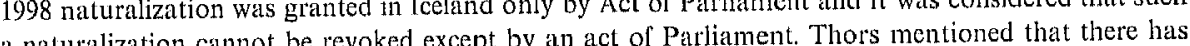
a naturalizhion cale 1998 naturalization is now mostly done by the administration in accordance with art. $5 \mathrm{a}$ of the Icelandic Nationality Act; thus, the question to revoke the naturalization because of fraud could now arise. But until now no such casc has come up.

85 Closset, Nr. 161. See infra par. IV(B)

6 Information provided by Jan Van De Velde, Advisor General, Ministry of Foreign Affairs, Brussels, in a letter of 13 December 2000. 
It may happen that a naturalization is acquired because of bribery of officials. Only the Mexican Provision is formulated on a way which undoubtely also covers this type of case. In all other countries bribery has to be classified as fraud. ${ }^{87}$

\section{Failure to Divest the Former Nationality}

In at least two countries, it is possible to revoke the naturalization because of the fact that a naturalized citizen did not divest himself of his old nationality ${ }^{88}$ In Austria, par. 34(1) states that a national shall be deprived of his Austrian nationality if (1) he acquired the nationality more than two years ago either through naturalization or extension of the naturalization; (2) he did not acquire his nationality because of special services in the field of science, economy, arts or sports in the interest of Austria; ${ }^{89}$ (3) on the day of naturalization (or extension of naturalization) he was not a refugee under the Convention of 1951 or the Protocol of 1967 on the status of refugees; and (4) despite the acquisition of Austrian nationality, retained a foreign nationality for reasons under his responsibility.

At least six months prior to the intended deprivation of nationality, the national involved has to be informed about the intended application of par. 34(1) A. After expiry of this period the deprivation shall be decreed without undue delay. After six years following the granting (or extension of granting), deprivation is no longer admissible. ${ }^{90}$

A similar provision is art. 15 (d) $\mathrm{NL}$, according to which a person of full age ${ }^{91}$ shall lose his Netherlands nationality by revocation of the decree granting Netherlands nationality make every effort to divest himself of his original nationality.

It is in my opinion dubious whether these grounds for revocation are covered by art. 7(b) ECN. Not fulfilling a promise cannot be classified as fraud, false information, or concealment of any relevant fact. Nevertheless, the explanatory memorandum on the ECN gives, as an example of the application of the present provision, the case that "a person acquires the nationality of the State party on condition that the nationality of origin would subsequently be renounced and the person voluntarily did not do so." According to the report, the state party would be entitled to provide for the loss of its nationality. I do not agree with this example for the reasons already mentioned. If the drafters had wanted to allow such a ground for loss, they should

87 See the cases reported in the (Belgian) Gazet van Antwerpen of 5 January 200

se

89 See par. 10(4), 16(2) and 17(4) A

so Statistics on the application of this provision are not avaitable; information of Peter Mak Bundesministerium für Inneres in a Ietter of 1 September 2000

I.e., a person who has attained the age of eighteen or has maricd before attuining that ares see art. $1 \mathrm{NL}$. have included it in the text of the treaty itself. ${ }^{92}$ Mentioning it in the explanatory report when it appears inconsistent with the plain wording of the text, is not enough. The view that revocation of naturalization because of not renouncing the previous The view that revocation of naturalization because of not renouncing the previous nationality is not covered by art. 7(b) ECN, is underscored by the fact that Austria
made the following reservation when it ratified the ECN. Such a reservation would be superfluous if Austria accepted the view manifested in the explanatory report:

Austria declares to retain the right to deprive a national of its nationality if:

1. he acquired the nationality more than two years ago either through naturalization or the extension of naturalization under the Law on Nationality of 1985 as amended;

2. neither Section 10, paragraph 4, nor Section 16, paragraph 2, nor Section 17 , paragraph 4, of the Law on Nationality 1985 as amended were applied;

3. on the day of naturalization (extension of naturalization) he was not a refugee as defined in the Convention of 28 July 1951 of the Protocol relating to the egal Status of Refugees of 31 January 1967, and

4. despite the acquisition of its nationality he has retained a foreign nationality for reasons he is accountable for.'

This reservation follows precisely the wording of par. 34(1) of the Austrian Nationality Act.

It is remarkable that a ground for loss corresponding with 34(1) A and 15(d) NL cannot be found in the German legislation. Obviously the opinion there is that this would violate art. 16 of the Basic Law, which forbids deprivation of nationality. ${ }^{93}$

\section{Revocation in Other Cases}

A considerable number of countries provide that in some other cases certainly no cossible $(23 \mathrm{~B}, 40 \mathrm{~GB}$ covered by art. 7(b) a revocation of a naturalization decree is possible (23 B, 40 GB, $19 \mathrm{IRL}, 27 \mathrm{~L}, 25 \mathrm{SP}, 37(\mathrm{~B})(1) \mathrm{MEX}, 340 \mathrm{USA}$ ). One should realize that in some cases the reasons for revocation may be covered by one of the other categories of art. $7 \mathrm{ECN}$, in particular by 7 (c) and (d), i.e., voluntary foreign military service or behavior seriously prejudicial to the vital interests of the state involved. Therefore these grounds for loss of nationality by revocation of a naturalization decree will be elaborated upon in par. 3 and 4 . Nevertheless, it must be stressed now that, because of art. 5(2) ECN, it is certainly not allowed to restrict these other grounds for loss to naturalized citizens.

92 In a previous draft of the explanatory reports "bigamy" was also mentioned as an cxample of the present provision. This example was later deleted. Compare Christine Kreuzer, StAZ 1997, 128.

3 Under certain circumstances Germany applies the sanction of a financial penalty if a naturalize citizen does not renounce his previous nationality, although he took this obligation during the naturalization procedure. See Allgemeine Verwaltungsvorschrift zum Staalsangehörigkeitsrecht of 18 October 2000, par. 8.1.2.6.2 
E. No Revocation Because of Fraud

In some countries revocation of a naturalization decree is never possible, even in cases where it was later discovered that the naturalization was acquired by fraud, mistepresentation, or concealment of relevant facts. This is, for example, the case in Sweden. ${ }^{94}$

F. Statelessness

The third and final paragraph of art. 7 of the Convention provides that, in principle, loss of a nationality may not cause statelessness. The only exception allowed to this principle is deprivation of nationality because of fraudulent conduct, false informaprinciple is deprivation of nationality because of fraudulent conduct, false informa-
tion, or concealment of any material fact during the naturalization or option procedure. But even here, Recommendation 99(18) of the Council of Europe states in Part C sub c: "In order to avoid, as far as possible, situations of statelessness, a State should not necessarily deprive of its nationality persons who have acquired its nationality by fraudulent conduct, false information or concealment of any relevant fact. To this effect, the gravity of the facts, as well as other such as the genuine and effective link of these persons with the state concerned, should be taken into account."

At the moment, loss of Netherlands nationality can never occur if this causes statelessness (art. 14 paragraph 2 Nationality Act). But as already mentioned, bill 25891 ( $R$ 1609) proposes to introduce the possibility to deprive a person of nationality if it was acquired by means of fraud even if statelessness is caused. In other States where revocation of a naturalization decree is possible in case of fraud, statelessness is accepted as well.

\section{G. Some Difficulties}

The first difficulty is whether naturalization of a person under a false name is valid and can, under certain circumstances, be revoked. Of course, it is obvious that in such a case it is almost always the naturalized person himself that provided false information as to his identity. In the Netherlands it was decided in several court decisions that the naturalization of a person under a false name is void in respect of the person who applied under this false name: it was not he, but another who was naturalized. ${ }^{95}$ A similar argument is followed by the authorities of the United Kingdom, where in such cases, the procedure of sec. 40 is not followed. It is remarkable that in Finland the authorities came to the opposite conclusion: the

94 Information from Bo Lundberg, Migrationsverket, in a letter 6 September 2000.

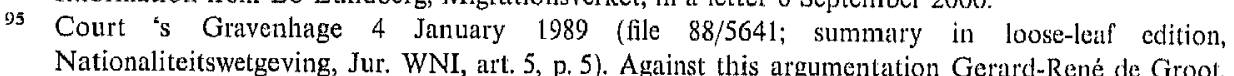
Comment 1 before art. 14 Netherlands Nationality Act, in: Personen- en Familierecht, loose-leaf edition, Kluwer Deventer. naturalization is regarded as valid. ${ }^{96}$ Also in Germany the false identity as such does not make the naturalization decree revocable. ${ }^{97}$

Of course it is not easy to determine what precisely are "relevant facts" that might support a finding of concealment. Importantly, attention should be paid to Recommendation 99(18), mentioned above where it is stressed that attention has to be paid to the gravity of the facts. Another related question is whether innocent false representation can allow deprivation as well. In some countries the answer is affirmative.

\section{H. Trends}

A general trend manifested by the European Convention on Nationality is the restriction of revocation of a naturalization decree to cases of fraud, misrepresentation, and concealment of relevant facts. Other grounds for loss should apply equally to citizens of origin and other citizens (see art. $7 \mathrm{ECN}$ in combination with art. 5(2) ECN).

Furthermore it can be observed that some countries limit the period within which Furthermore it can be observed that some countries limit the period within which
revocation can take place (Switzerland: 5 years; Austria: 6 years; Netherlands (prorevocation can take place (Switzerland: 5 years; Austria: 6 years; Netherlands (proposed bill) 12 years (with exceptions); Spain: 15 years). The ECN does not prescribe this limitation, but Recommendation $99(18)$ underscores that in applying this ground involved with the state concerned. If a long period has passed since the naturalization, normally such a close and genuine link exists in spite of the fraud that was committed in the past. Limiting the period within which a revocation is possible amounts to a practical implementation of the Recommendation.

\section{VOLUnTARY FOREIGN MILITARY SERVICE ${ }^{98}$}

\section{A. General Remarks: Treaties}

Art. 7(c) ECN allows for loss of nationality because of voluntary service in a foreign military force. The explanatory memorandum on the ECN explains that it does not matter whether the person involved served in the official army of another state or not. The provision covers every voluntary military service in any foreign military force irrespective of whether it is part of the armed forces of a foreign state. A corresponding provision cannot be found in the 1961 Convention on the Reduction of Statelessness. However, a certain parallel can be seen in art. 8(3):

96 Allan Rozas/Markku Suksi, in Bruno Nascimbene, Finland, 293, note 56, with reference to an opinion delivered by the Chancellor of Justice on 9 July 1987 (Nr. 2855).

97 Von Klüchtzer, 131

98 Gerard-René de Groot, Staatsangehörigkeitsrecht in Wandel, o.c., 298-300; compare as well the detailed paper of Stephen Legomsky, Dual Nationality and Military Service: Strategy Number Two, this volume. 
Notwithstanding the provisions of paragraph 1 of this Article, a Contracting State may retain the right to deprive a person of his nationality, if at the time of signature, ratification or accession it specifies its retention of such right on one or more of the following grounds, being grounds existing in its national law at that time.

(a) that, inconsistently with his duty of loyalty to the Contracting State, the person

(i) has, in disregard of an express prohibition by the Contracting State rendered or continued to render services to, or received or continued to receive emoluments from, another State, or

(ii) has conducted himself in a manner seriously prejudicial to the vital interests of the State;

(b) that the person has taken an oath, or made a formal declaration, of allegiance to another State, or given definite evidence of his determination to repudiate his allegiance to the Contracting State.

But in that case the state involved has to observe art. 8(4) as well:

A Contracting State shall not exercise a power of deprivation permitted by paragraphs 2 or 3 of this Article except in accordance with law, which shall provide for the person concerned the right to a fair hearing by a court or othe independent body.

Of course, according to art. $7 \mathrm{ECN}$, voluntary military service can never cause statelessness. In this respect, art. 7(c) is in accordance with the 1961 Convention. On the other hand a procedural guarantee such as art. 8(4) of the 1961 Convention would be quite desirable in respect of this ground for loss, in particular if loss is also possible in the case of military service in a military force that is not a part of the armed forces of another state. It is not difficult to imagine that in that case many interpretive difficulties may arise.

\section{B. Loss ex lege}

In some states ex lege loss of nationality is provided for in the case of voluntary foreign military service, but in all cases studied, the provisions involved deal with voluntary military service of another state, not with service in non-state military forces.

An example is par. $32 \mathrm{~A}$, which provides that a national who voluntarily enters the military service of a foreign country shall lose Austrian nationality. If the person involved is still a minor at the moment when he enters the foreign military service, the previous consent of his legal representative is required. If the legal representative is not a parent of the minor involved, previous permission of the court (more precisely: "Vormundschafts- oder Pflegschaftsgericht") is necessary (see par. 27(2)). ${ }^{99}$

99 Regrettably, no statistical data are available on the application of par. 32; information given by Peter Mak, Bundesministerium für Inneres, in a letter of 1 September 2000. Corresponding older Austrian provisions were par. 10 Act 1925 and par. 9 Act 1945/1949.
If a dual national fulfills his military obligations in his other state he does not lose Austrian nationality, unless he voluntarily commits acts which go beyond normal mandatory military service. ${ }^{100}$

mandatory military service.

Until 1985, Netherlands nationality law contained voluntary foreign military service (or state service) without the permission $\mathrm{n}^{101}$ of the King of the Netherlands as a ground for ex lege loss of Netherlands nationality (art. 7(4) Nationality Act
$1892)^{102}$ But the Netherlands had very bad experiences with this ground for loss during the 1930s and 1940s. Several persons who went into German military service during the period of the Second World War rejected the jurisdiction of the Netherlands in respect of crimes possibly committed by them during that period, Netheriands in respect of crimes possibly commitved - they would have committed because - if they had committed the crimes involved - they would have committed them as non-Netherlands citizens in a foreign country. These jurisdiction problems military service as a ground for loss will be reintroduced in the near future. Bill 25 891, as amended in the Second Chamber of Parliament, proposes to add to art. 15 a proviso that Netherlands nationality will be lost (ex lege) if a national voluntarily a proviso the Nilitary enters into the milltary involved is a reaction to the fact that some (naturalized) Netherlands nationals participated as soldiers in the armed conflicts in former Yugoslavia.

Dual nationals with German nationality also participated in the armed conflict in Yugoslavia. Therefore, a similar provision was added on 1 January 2000 to the German nationality act $(28 \mathrm{G})$ : a German who voluntarily enters into the armed for 104 of and Verband eines aulünisch Verband eines ausles German nationality if he entered the foreign military service without the consent of the German authorities in accordance with par. 8 of the German statute on military service ("ohne eine Zustimmung nach par. 8 des Wehrpflichtgesetzes"). In the past, Germany had corresponding provisions (par. 22 Act 1870; par. 28 Act 1913), but it

$\overline{100}$ Zeyringer, Nr. 84.

It has to be stressed that this permission also could (and even nowadays still can) be given after a person entered the foreign military service.

Dolder provisions werc art 9(2) Civil Code 1838 and art. 10(2) Act 1850

103 The Dutch text The stat die betrok ken is bif gevechtshas (amendment Nr. 30 of 17 February 2000). In amendment Nr. 15 of 15 February 2000 a more general formulation was chosen "zich in vreemde krijgsdienst begeeft of zich aansluit bij een vreemde groepering," which would also include military scrvice of a non-state entity. Because of critical remarks of the Ministry of Justice on difficulties with the application of the proposed ground of loss in concrete cases, it was decided to replace this amendinent by the later accepted version, which only regards military service of a foreign statc.

104 The Allgemeine Verwaltungsvorschrift zum Staatsangehörigkeitsrecht of 18 October 2000 gives as examples a special unit of the police ("Polizeisondertruppe") or a paramilitary state organization ("paramilitärische staatliche Organization"). 
was generally accepted that this ground for loss was a forbidden deprivation of nationality in the sense of art. 16(1) of the German Constitution. ${ }^{105}$ A difference between the old and the new provision is that under par. 28 Act 1913 making foreign military service a ground for deprivation, the German authorities had a margin of appreciation. ${ }^{106}$ In the new statute the loss occurs ex lege and seems therefore not appreciation. ${ }^{106}$ In the new statute the loss occurs ex lege and seems therefore not
to give a margin of appreciation to the German authorities. Nevertheless, the German to give a margin of appreciatisitios the porill have the possility to avoid the loss involved by granting the consen under par. 8 of the German statute on military service. It has to be expected and hoped that the new provision shall be challenged very soon in regard of its accordance with art. 16(1) of the German Constitution.

In respect of voluntary military service, Austria made a surprising reservation as regards art. 7(c) ECN on the occasion of its ratification of the ECN: "Austria declares to retain the right to deprive a national of its nationality, if such person voluntarily enters the military service of a foreign State." The reservation follows the wordin of par. 32 of the Austrian Nationality Act, but seems to me to be superfluous. The provision in art. 7(c) allows for loss of nationality because of foreign military service ex lege or on the initiative of a State in a particular case. The Austrian ground for loss is covered by this provision. Did of voluntary milit of voluntary military service deprivation of nationality will take place, because minors only lose their nationality if their legal representative has expressed his consent (see par. 27(2) A in combination with par. 32 A)? Or did Austria want to express that only military service for a foreign state and not the service in a nonstate military force results in deprivation? Because of the fact that art. 7 of the Convention allows the deprivation of nationality only in the cases mentioned and does not oblige a state party to deprive a national of nationality in those cases, the Austrian reservation can be withdrawn.

\section{Deprivation Because of Foreign Military Service}

Exclusively in Moldova, foreign military service is not mentioned as a ground for loss of nationality ex lege but as a ground for deprivation (art. 23(1)(b)). The article provides that the nationality "may be" ("poate fi") revoked in such a case. Therefore provides that the nationality "may be" "poate $f$ ") revoked in such a case. Therefore
the president of Moldova obviously has a margin of appreciation. The Moldovan regulation is in conformity with art. 7(c) ECN.

${ }^{105}$ So for example Franz Massfeller, Deutsches Stantsangelörigkeitsreclit, 2nd edition, Frankfurt an Main/ Berlin 1955, 65: "par. 28 steht im Widerspruch zu art. 16 Abs. 1 Sa1z 1 GG und ist deshlo gegenstandlos geworden.

${ }^{106}$ According to Massfeller, 65 par. 28 violated also art. 16(1) Constitution in cases where the national involved also possesses the nationality of the state in which military service he undertook: "Dies gill auch für den Fall, in dem der Betrofene neben der deulschen Stalatsangehörigkeit eine fremde Staatsangehorigkeit besitzt (z.B. die des Dienstherrn), durch den Entzug der deutschen Staatsangehörigkeit also nicht staatenlos würcle,. ..."
D. Foreign Service

A considerable number of countries provide for the possible loss of nationality in cases of foreign service, without making a distinction between military service and civil service. In France art. 23-8 $\mathrm{F}^{107}$ makes it possible to deprive a. French national civil service. In France art. $23-8 \mathrm{~F}^{107}$ makes it possible to deprive a. French national
of his nationality if he does not resign the service in a foreign army or foreign public service or service of an international organization in which France does not participate ("un emploi dans une armée ou un service public étranger ou dans une organization internationale dont la France ne fait pas partie"). The same applies for general support of a foreign state or international organization ("ou plus généralement leur apportant son concours"), if the French government requests the person to desist. The intended deprivation has to be communicated to the person involved and term not shorter than 15 days and not longer than two months has to be given to stop the foreign employment.

Less detailed is art. $20(1)(\mathrm{b}) \mathrm{GR},{ }^{108}$ according to which a Greek citizen may be declared to have forfeited Greek citizenship if he accepted a public office in another country and he remains there even after an order by the Minister of the Interior to abstain from his service within a defined time limit. Compare also the provision of art. 14(1) GR, according to which a Greek citizen will lose his Greek citizenship if, after permission, he acquired a foreign citizenship by his own will or if he accepted after permission, he acquired a foreign citizenship by his own will or if he accepted
public service in another country that results in acquisition of the citizenship of that public service
country.

A comparable regulation can be found in Italy, where art. 12(1) I provides that an Italian citizen shall lose his citizenship if he accepted a public office from a foreign state or a forcign public body or an international body to which Italy does not belong, or he joins a foreign army ("un impiego pubblico od una carica pubblica da uno Stato o ente pubblico estero o da un ente internazionale cui non partecipi uno Stato o ente pubblico estero o da un ente internazionale cui non partecipi
l'Italia, ovvero prestando servizio militare per uno Stato esterno"), unless he obeys, I'Italia, ovvero prestando servizio militare per uno Stato esterno"), unless he obeys,
within a fixed term, an order of the Italian government to abandon the office or the military service. In wartime, different rules apply (12(2) I). In that case an Italian citizen shall lose his Italian citizenship when the state of war ceases, if during the state of war against a foreign State: a) he accepted or did not abandon a public office of that foreign State; or b) he served in the army of this state without being obliged to do so. ${ }^{110}$

107 Paul Lagarde, in Nascimbene, 323 mentions that this provision is not applicd in practice. Lagarde confirms this in an E-mail of 14 January 2001. However, he mentions that the French governmen sometimes (but not often) formally requests a person to stop a certain foreign employment.

100 Anastasia Grammaticaki-Alexiou, in Nascimbene, 400; compare Marrie-Hélène de BrabandereMarescaux/Sophia Koukoulis-Spiliotopoulos, Nr. 93

${ }^{109}$ This permission is only very rarely given. Information provided by Zoe Papassiopi-Passia in al letter of 16 January 2001.

10 Stefania Bariatti, Italie, Nr. 84, 85, in: Charles L. Closset/ Michel J. Verwilghen, Jurisclasseur Nationalité, Paris, loose-leaf edition, underscores that this ground for loss corresponds with art. 8(3) of the Italian nationality act of 1912, which was never applied. Furthermore, she argues that this 
In Spain, voluntary foreign military or civil service ("cuando entren voluntariamente al servicio de las armas o ejerzan cargo político en un Estado extranjero") has since 1982, not been a general ground for loss ex lege, but it is such a ground exclusively for naturalized citizens ("los españoles que no lo sean de origen"), if the government has forbidden the service involved expressly (25(1) SP). Not all foreign civil service can have this consequence, but exclusively political functions (cargo politico). ${ }^{111}$

In the United States, sec. 349 provides for loss of American citizenship in the following cases:

(3) entering, or serving in, the armed forces of a foreign state if

(A) such armed forces are engaged in hostilities against the United States, or

(B) such persons serve as a commissioned or non-commissioned officer; or

(4) (A) accepting serving in, or performing the dutice of any offce, post or employment under the government of a foreign state or a politica

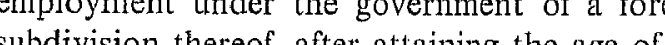
subdivision thereof, after attaining the age of eighteen years if he has or acquires the nationality of such foreign state; or

(B) accepting, serving in, or performing the duties of any office, post, or employment under the government of a foreign state or a political subdivision thereof, after attaining the age of eighteen years for which office, post, or employment an oath, affirmation, or declaration of allegiance is required; or

(7) committing any act of treason against, or attempting by force to overthrow, or bearing arms against, the United States, violating or conspiring to violate any of the provisions of section 2383 of title 18, United States Code, or willfully performing any act in violation of section 2385 of title 18, United States Code, or violating section 2384 of said title by engaging in a conspiracy to overthrow, put down, or to destroy by force the Government of the United States, or to levy war agains them, if and when he is convicted thereof by a court martial or by a court of competent jurisdiction.

However, in view of the previously mentioned decisions of the U.S. Supreme Court regulation could violate art. 22 of the Italian Constitution, which lorbids depriving somebody of
Italian nationality for political reasons ("per motivi politici") Nevertheless, this included in the nationality act of 1992 . Obviously, the Italian legisistator concluded that art. 54 of the Constitution (regarding the obligation of loyalty to the republic) prevails in this context above art. 22. See also the critical remarks of Stefinnia Bariatti, in Nascimbene, 484

111 Elisa Perez Vera/ Jose Maria Espinar Vicente, Espagne, Nr. 90, in: Charles L. Closset/ Michel J. Verwilghen, Jurisclasseur Nationalité, Paris, loose-leal edition, under'score that this ground for loss is interpreted restrictively, although a Decree of 28 December 1967 forbics all Spaniards to go voluntarily into foreign military service. They refer to the resolution of the DGRN of 24 July 1968. See as well José Carlos Fernandez Rozas/ Aurelia Alvarez Rodrigues, in Nascimbene, 239, who are of the opinion
that this Decree is no longer in force. in Afroyim v. Rusk and Vance v. Terrazas, ${ }^{112}$ it is necessary to conclude that American citizenship will be lost only if the person involved had the intent to give up the said citizenship. ${ }^{13}$

In Mexico art. 37(C) provides for the loss of Mexican "ciudadanía" inter alia because of voluntary service for a foreign government without permission of the competent Mexican authorities. However, this provision does not deal with the loss of nationality, but exclusively with the loss of citizenship rights. Art 34 of the Constitution makes a sharp dist constitus mexican nationality ("lo possess Mexican nationality ("los varones y mujeres que, teniendo la calidad de Mexicanos"). Furthermore, one notices the distinction between "nacionalidad" and "ciudadania" as well in the text of art. 37, where art. 37(A) and (B) speak about "podrá ser privado de su nacionalidad," whereas art. 37(C) uses the words "La ciudadanía mexicana se pierde."

Art. 25(A)(b) TURK states that service to a foreign state in a way that conflicts with the interests of Turkey is a reason for deprivation of nationality if the person involved does not obey the order of the Turkish authorities to abandon the foreign service within a period, which has to be no less than three months. Art. 25(A)(c) TURK provides that the continuation of voluntary service of another state with which Turkey is at war is a ground for deprivation of nationality, if the Turkish authorities did not give permission to continue the service. ${ }^{114}$

In the Scandinavian countries, foreign service is a ground for loss only if the national involved acquired a foreign nationality by taking up the foreign position. An example is art. 7(2) DK, according to which Danish citizenship shall be forfeited by a person who acquires a foreign nationality by taking up a position with the public authorities of another country. It has to be stressed that acquisition of a nationality by accepting a position with a foreign state is, in contemporary nationality law, very rare. Examples are par. $25 \mathrm{~A}$ (acquisition of Austrian nationality by an appointment as a professor at an Austrian university), art. 21-11 F (acquisition of French nationality by entering the French military service), and art. 4(1)(a) and (b) I (acquisition of Italian nationality by persons of Italian descent entering Italian military or state service). ${ }^{115}$

Almost identical provisions can be found in the nationality legislation of the other Scandinavian countries: 8(2) FIN, 7(2) IC, ${ }^{116} 7(2)$ N, 7(2) SW. However, in Sweden bill 2000:147 proposes to abolish this ground for loss.

\section{See above footnotes 51 and 52}

113 Alfred del Rey, Nr. 109, 110

4h See on both provisions the paper of Christian Rumpf, Citizenship and Multiple Citizenship in Turkish Law, this volume. There are no statistical data concerning the application of the $\operatorname{Art} 25(\mathrm{~A})(\mathrm{b}, \mathrm{c})$ becaluse Ministry (The Genera Dirction Departme in an ormil of 233 ctober 2000 ). 2000)

116 Art 7(2) IC bus

applied as the information received about an Icelandic nationa 
In most countries the loss is not an ex lege loss, but occurs only after an order of the government, which makes it possible to control whether the voluntary service is indeed an indication of the intent of the person involved to give up his nationality. In Austria, a special provision of the nationality act deals with foreign civil service. Par. 33 A provides that a national in the service of a foreign country shall be deprived of nationality, unless sec. 32 already applies (i.e., loss ex lege because of voluntary military service of a foreign country), if the national, through his behavior, severely damages the interests or the reputation of the Republic. ${ }^{117}$

In order to maintain this ground for loss, Austria made the following reservation when it ratified the ECN:

Austria declares to retain the right to deprive a national of its nationality, if such person, being in the service of a foreign State, conducts himself in a manner seriously prejudicial to the interests or the reputation of the Republic of Austria.

\section{E. Foreign (Military) Service as Prejudicial Behavior}

Some countries do not provide foreign (military) service as a ground for loss of their nationality, but include in their nationality legislation provisions which create the possibility of deprivation of nationality in case of a behavior seriously prejudicial to the state. If that is the case, it may happen that foreign (military) service is classified as such behavior. That is for example the case in Belgium ${ }^{118}$ and Luxembourg. ${ }^{119}$

\section{F. Statelessness}

Voluntary civil service is not allowed by art. $7 \mathrm{ECN}$ as a ground for loss. All the provisions mentioned are valid only in respect of the voluntary military service. The Spanish provision violates art. 5(2) ECN because of the discriminatory treatment of naturalized citizens. As a consequence of art. 7(3) ECN, loss of nationality because of foreign military service may not cause statelessness. Some national provi nevertheless do not explicitly exclude the possibility of statelessness and ar therefor not completely acceptable in view of the ECN. nationality. Information provided by Jón Thors, Dóms- og Kirkjumálar Áduneytid (Ministry of Justica
and Ecclesiastical Affairs), Reykjavík in a letter of 17 November 2000. 17 Regrettably no statistical data are available on the applientior 2000.

Peter Mak, Bundesministerium fur In Inerse on were in the past, par. 10 Act 1925 and par. 9 Act 1945/1949.

18 See a letter with comparative remarks on the consequences of foreign paramilitary service by $\mathrm{M}$ Jot Cohen to the parliament of the Netherlands d.d. 8 September 2000 paramilitary service by M. Jo 1909, Belgium had a more specific provision: art. 17(2) and 22 Civil Code.

Fernand Schockweiler, Luxembourg, Nr. 85, in: Charles L. Closset/Michel J. Verwilghen, Jurisclasseur Nationalité, Paris, loose-leaf edition, with reference to Décl. min. just., CR 1938/39, 1075 ("service militaire ou paramilitaire"); See also the same author, in Nascimbene, 519.

\section{G. Difficulties}

A first difficulty in respect of the interpretation of various cited provisions is: what precisely is a military force of a foreign state? This is particularly difficult in respect of States with only one political party participating in the government if this party has its own quasi-military force, such as in Nazi Germany the "SS" of the National Socialist Party. A second difficult point is determining whether somebody voluntarily entered into foreign service. Can one still conclude that entering the service happened voluntarily if the alternative would be to leave the country involved, although one was already living there for a very long period? ${ }^{120} \mathrm{~A}$ further question is whether the provisions involved also apply to minors. The Austrian regulation answers this question in principle in the negative. In the Netherlands the old provision of art. 7(4) was never applied to minors, because this would conflict with the genera protection of minors against their own imprudent decisions. In respect of severa cited provisions the answer is not clear. For the Member States of the European Union, it must finally be stressed that loss of nationality because of service to another Member State could violate European Union law under certain circumstances if the foreign service does not imply, as such, the exercise of political power or sovereignty rights. ${ }^{12}$

\section{H. Trends}

In spite of the formulation of art. 7(c), one can observe that states generally do no allow deprivation of nationality based on joining a non-state military force, largely because of the legal uncertainty such a regulation would cause in practice. Further, although deprivation of nationality because of foreign civil service is still mentioned in a considerable number of nationality acts, the tendency is to abolish this ground of loss. ${ }^{122}$

\section{SERIOUS PREJUDICIAL BEHAVIOR ${ }^{123}$}

\section{A. General Remarks: Treaties}

Art. 7(1)(d) ECN allows the deprivation of a nationality because of conduct in a manner seriously prejudicial to the vital interests of the state party. The wording of

${ }^{20}$ The government of the Netherlands decided in 1988/1989, that an acquisition of the nationality of South Africa based on art. 11A nationality act (acquisition of nationality of South Africa by all persons in the age between 15 and 25 years, if they possess a permanent residence permit and live for a period of five years in South Africa) cannot be classified as voluntary, although a possibility to opt out existed, because lodging an opt out declaration had as a consequence that one had to leave the
country. See "Kamerstuk" 21165 . 121 Conpure Hildenad Scheider, Dis A

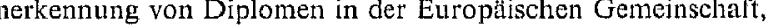
122 See for example Itall in

123. Gerard-René de Groot, Staatsangehörigkeitsrecht im Wandel, o.c., 301, 295-298. 
this sub-paragraph is drawn from art. 8(3)(a)(ii) of the 1961 Convention on the Reduction of Statelessness. The explanatory report on the ECN stresses that the conduct involved includes notably treason and other activities directed against the vital interests of the state concerned - for example, work for a foreign secret service - but does not include criminal offenses of a general nature, however serious they may be.

It is important to compare the formulation of art. 7(d) ECN with the complete text of art. 8(3) of the 1961 Convention, which is set forth in Part III(A) supra. One then notices that certain acts that could be the basis of a deprivation of nationality under the latter treaty are obviously not covered by the provision of art. 7(1)(d) ECN. Specifically, art. 7(1)(d) ECN does not cover the categories mentioned in the 1961 Convention in art. 8(3)(a)(i) and 8(3)(b). To render services to a foreign state or to receive emoluments from another state cannot be automatically classified as behavior seriously prejudicial to the vital interests of a state. And the same applies for taking an oath, making a formal declaration of allegiance to another state, or even engaging in behavior that gives "evidence of [the citizen's] determination to repudiate his allegiance" to the state at issue.

B. National Provisions

In a considerable number of countries, no ground for loss corresponding with art 7(1)(d) ECN exists. This is the case in Canada, Germany, ${ }^{124}$ Italy, ${ }^{125}$ Netherlands, $7(1)(d)$ ECN exists. This is the case in Canada, Germany,
Poland, ${ }^{126}$ Portugal, ${ }^{127}$ and all the Scandinavian countries.

Other countries provide for loss of nationality on grounds that could be qualified,
oland, in certain circumstances, as behavior seriously prejudicial to the vital interests of a state. But most provisions are drafted in rather wide and vague terms.

In Belgium art. 23(1) provides that naturalized Belgian citizens (more precisely: "les Belges qui ne tiennent pas leur nationalité d'un auteur belge au jour de leur naissance") may be deprived of their Belgian nationality if they seriously neglect their obligations as a Belgian citizen ("s'ils manquent gravement à leurs devoirs de citoyen belge"). ${ }^{128}$ This ground for loss was introduced into Belgian nationality law in $1934^{129}$ and was taken over in the Belgian Nationality Act of 1985 with relevant

${ }^{124}$ This would be against art. 16 Constitution. See in the past par. 2 Act 1870; parr. 27 Act 1913. 126 This would be contrary to art. 22 Constitution, See for the past the Act of 31 January 1926. See art. 34 (2) Constitution, which provides that a Polish citizen cannot be deprived of his nationality 127 .

Jurisclasseur National-Gobbe, Portugal, Nr. 90, in: Charles L. Closset/ Michel J. Verwilghen, ality because of the Portuguese constitution which forbids deprivats of the state would be contraly to art. 30(4) of 128 Since 1991, Belgians of foreign origin who acquired Belgian nationality beced on political grounds. as well from this ground of loss. See J. K. Carlier / S. Goffin in Nascimbene, 147. Art. 18 bis Act 1932, introduced by Act of 30 July 1934, Moniten bet of 5 Aut

1934, 248. See Gerard-René de Groot Staatsangehörigkeitsrecht im Wundel ougust 1934; Pasinomic of 1934 had its roots in an Act of 25 October 1919 which allowed deprivation. Sce furthernore on modifications. ${ }^{130}$ The procedure of deprivation can be started by the public prosecutor, who has to indicate precisely which acts are classified as negligence of the obligations of a Belgian citizen. According to the preparatory documents on the act of 1934, the citizen in question must have acted manifestly against his obligations; deprivation is not possible because of a different religion or race. The main reason or the application of the provision is a thre and to already mentioned in Part II(B), fraud, misrepresentation, and similar acts during the naturalization procedure can also be classified as a serious neglect of the obligations as a citizen. ${ }^{132}$ The same applies for voluntary military service in another state.

In France art. 23-7 $\mathrm{F}$ provides that a French national who conducts himself properly as a national of a foreign state ("qui se comporte en fait comme le national d'un pays étranger") can be deprived of his French nationality by a "décret" with the consent of the Conseil d'État, if the person involved also possesses the nationality of that foreign country. In practice this provision is not applied if somebody, for example, fulfills an (elected) public function in a foreign country, but only if he damages the interests of France or commits hostile acts. ${ }^{133}$

Of relevance in this context moreover is art. $25 \mathrm{~F}$. This article starts with the following words:

L'individu qui a acquis la qualité de Français peut, par décret pris après avis conforme du Conseil d'État, être déchu de la nationalité française:. ...

This implies that an individual who has acquired French nationality can be deprived of his nationality by a décret with the consent of the Conseil d'État, if one of the facts mentioned in art. 25 occurred. Reading this provision, one has to realize that French nationality regulations distinguish between attribution of the nationality "d'origine" (articles 18-20-5 Cc) and acquisition of the nationality (articles 21-22-3 Cc). The deprivation based on this article is only possible, if the person involved has acquired French nationality, not if French nationality was attributed.

A deprivation based on art. $25 \mathrm{~F}$ is possible, if one of the following conditions is

the procedure of deprivation the Acts of 15 May 1922 and 4 August 1926. By Decree of 6 May 1944 the art. 18 ter and 18 quater were introduced in the Act of 1932 making it possible to deprive also Belgians of origin of their nationality in case of conviction in absence for acts committed during World War II. These last articles were not taken over in the Act of 1985.

${ }^{130}$ See Michel Verwilghen, Le code de la nationalité belge, Bruxelles 1985, 412-419.

${ }^{31}$ The predecessor of art. 23(1) (art. 18 bis Act 1932) was belore the war of 1940-1945 applied in four cases, directly after the war in 34 cases. Since then art. 18 bis and art. 23 have not been applied mation provided by Jan a letter of 13 December 2000

${ }_{332}$ Closset, Nr. 161

Hugues Fulchiron/ Savinien Grignon Dumoulin, France, Nr. 219, in: Charles L. Closset/ Michel J. Uationalité, Paris, Joose-leaf edition. See on this provision as well, Paul not used since 1973. 
fulfilled: the person involved is sentenced for a crime which implies a danger to the fundamental interests of the nation ("s'il est condamné pour un acte qualifié (L.n 93-933 du 22 juill. 1993) de crime ou délit constituant une atteinte aux intérêts fondamentaux de la Nation"); when the naturalized citizen is condenned for a certain crime ("s'il est condamné pour un acte qualifié (L.no 93-933 du 22 juill. 1993) de crime ou délit prévu et réprimé par le chapitre II du titre III du livre IV du Code obligations ("s'il est condamné pour s'être soustrait aux obligations résultant pour lui du Code du service national"); when he was involved in acts profitable for a foreign state, which were incompatible with the status of a French national and prejudicial to the interests of France ("s'il s'est livré au profit d'un État étranger à des actes incompatibles avec la qualité de Français et préjudiciables aux intérêts de la France"); or finally, if he was condemned to at least five years imprisonment ("s"il a été condamné en France ou à l'étranger pour un acte qualifié de crime par la loi française et ayant entraîné une condamnation à une peine d'au moins cinq années d'emprisonnement").

According to art. 25-1 F, deprivation of nationality based on the grounds of art. $25 \mathrm{~F}$ is possibie only within a period of ten years after the acquisition of French nationality. Furthermore deprivation is not possible more than ten years after the commission of the acts involved.

The Greek provision of art. 20(1)(c) G is considerably less detailed. ${ }^{134}$ A Greek citizen may be declared to have forfeited Greek citizenship if, while he was residing in another country, he acted for the benefit of that country and against the interest of Greece. 135

The United Kingdom has a very elaborate regulation of deprivation of British nationality for naturalized nationals (including those who acquired citizenship by registration). ${ }^{136}$ Deprivation of nationality by order of the Secretary of State is, according to sec. 40 (3) UK, possible if the citizen involved

(a) has shown himself by act or speech to be disloyal or disaffected towards Her Majesty; or

(b) has, during any war in which Her Majesty was engaged, unlawfully traded or communicated with an enemy or been engaged in or associated with any business that was to his knowledge carried on in such a manner as to assist an enemy in that war; o

${ }^{134}$ Anastasia Grammaticaki-Alexiou, in Nascimbene, 401, 402

${ }^{355}$ See on this privison Zoc Papassiopi-Passial, The Greek Nationality Law in a Nutshell, Review The dentivation oil

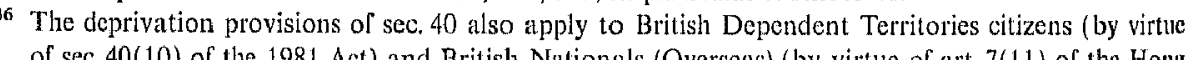
Kong (Britisl Nationlity) Order 1986). Naformation provided by Andrew Hirst Policy Section (c) has, within the period of five years from the relevant date, been sentenced in any country to imprisonment for a term of not less than twelve months...

Sec. $40(5)$ prescribes, in addition, that the Secretary of State

(a) shall not deprive a person of British citizenship under this section unless he is satisfied that it is not conducive to the public good that that person should continue to be a British citizen; and

(b) shall not deprive a person of British citizenship under subsection 3) on the ground mentioned in paragraph c) of that subsection if it appears to him that that person would thereupon become stateless.

In case of deprivation based on sec. 40(3)(a) or (b) UK, statelessness is possible which conflicts with art. 7(3) ECN.

The procedure to be followed in case of an intended deprivation is regulated by sec. $40(6)-(8)$ :

(6) Before making an order under this section the Secretary of State shall give the person against whom the order is proposed to be made notice in writing informing him of the ground or grounds on which it is proposed to be made and of his right to an inquiry under this section.

(7) If the person against whom the order is proposed to be made applies in the prescribed manner for an inquiry, the Secretary of State shall, and in any other case the Secretary of State may, refer the case to a committee of inquiry consisting of a chairman, being a peson possessing judicial experience, appointed by the Secretary of State and of such other member appointed by the Secretary of State as he thinks proper.

(8) The Secretary of State may make rules for the practice and procedure to be followed in connection with references under subsection (7) to a committee of inquiry; and such rules may, in particular, provide for conferring on any such committec any powers, rights or privileges of any court and for enabling any powers so conferred to be exercised by one or more members of the committee.

The Irish regulation has much in common with the British. sec. 19(1) IRL states:

The Minister [for Justice] may revoke a certificate of naturalisation if he is satisfied - ... (b) that the person to whom it was granted has, by any overt act, shown himself to have failed in his duty of fidelity to the nation and loyalty to the State, or

(d) that the person to whom it is granted is also, under the law of a country at war with the State, a citizen of that country, or

In respect of the procedure to be followed, sec. 19(2) and (3) IRL prescribes that:

(2) Before revocation of a certificate of naturalisation the Minister shall give 
such notice as may be prescribed to the person to whom the certificate was granted of his intention to revoke the certificate, stating the grounds therefore and the right of that person to apply to the Minister for an inquiry as to the reasons for the revocation.

(3) On application being made in the prescribed manner for an inquiry under subsection (2) the Minister shall refer the case to a Committee of Inquiry appointed by the Minister consisting of a chairman having judicial experience and such other persons as the Minister may think fit, and the Committee shall report their findings to the Minister.

The Luxembourg regulation is inspired by both the Belgian ${ }^{137}$ and French nationality legislation. According to art. $27 \mathrm{~L}$, deprivation of nationality is possible on the application of the public prosecutor in case of a naturalized person (more precisely. "le Luxembourgeois qui ne tient pas sa nationalité d'un auteur luxembourgeois al jour de sa naissance"), if he seriously neglects his obligations as a Luxembour jour de sa naissance"), if he seriously neglects his obligations as a Luxembourg
citizen, ${ }^{138}$ he exercises rights or fulfills obligations as a foreign national, ${ }^{139}$ or he was sentenced because of certain crimes exhaustively listed. ${ }^{140}$

In Moldova art. 23(1)(c) allows the deprivation of nationality in case of actions (the vital interests of the state ("esentiali statului"), which are proved by the court.

Spain provides in art. 25(1)(a) SP that for naturalized Spanish nationals ("los españoles que no lo sean de origen"), deprivation of their nationality is possible if a sentence condemns them to the loss, according to the rules established by the criminal law. This sanction plays a role in case of delicts against the external security of the state ${ }^{141}$

In Switzerland art. 48 makes it possible for the Ministry of Justice to deprive a dual citizen of his Swiss nationality if his behavior severely damages the interests or the reputation of Switzerland ("wenn sein Verhalten den Interessen oder dem Ansehen der Schweiz erheblich nachteilig ist"). ${ }^{142}$

The Turkish nationality legislation contains a long list of other grounds for deprivation of nationality. Art. 25 mentions, as a ground for loss for nationals living abroad, the refusal to fulfill within three months their military obligations if they are summoned to defend Turkey in case of a declaration of war abroad, refusal to return

${ }^{137}$ See Fernand Schockweiler, in: Charles L. Closset/ Michel J. Verwilghen, Jurisclasseur Nationalité, Paris, loose-leaf edition, Luxembourg, Nr. 84

${ }_{139}$ Compare the previou

${ }^{140}$ Compare the previously mentioned art. $25 \mathrm{~F}$. Statistical data on the appliation of these provisols are nol available. These grounds for loss were applied by the Luxembour cou a pere pronsions World War. Information provided by M. A. Ketter in a letter of 28 September 2000 . ${ }_{141}$ Art. 141 Codigo Penal, See Elisa Perez Vera/ José Maria Espinar Vicente Nr. 89.

142 According to Roland Schärer, Swiss Nationality Section, in an E-mail of 15 January 2001, art. 48 has not been applied for about 50 years. He mentions also that about 15 years aro it could not be applied to a member of the Italian Red Brigades because it would have rendered that person stateless. after a desertion from the Turkish army, or, for members of the armed forces staying abroad on holidays, etc., failure to return within three months after the leave period involved. ${ }^{143}$ The previously mentioned grounds for deprivation apply for all Turkish citizens. For naturalized Turkish nationals, art. 26 declares that a further ground for deprivation is staying abroad and refusing to come back to Turkey within three months ${ }^{144}$ after a summons given by the Turkish authorities, if the person involved committed criminal acts against the economic or financial security of Turkey. In In the United States a con 349(a)(7) INA regarding acts of treason, attempting by force to overthrow the government, or bearing arms against the United States ${ }^{145}$ Furthermore sec. 340 of the statute provides for revocation of a naturalization decree based on acts committed after the naturalization. Specifically, based on a conviction for a refusal on the part of a naturalized citizen within a period of ten years following his naturalization to testify as a witness in any proceding before a congressional committee concerning subversof organization, membership in or affiliation with which at the time of naturalization would have precluded such person from naturalization. Each of these grounds for loss of citizenship would appear to be unconstitutional absent additional proof that the person involved specifically intended to relinquish U.S. citizenship, under the Supreme Court's rulings in Afroyim v. Rusk and Vance v. Terrazas. ${ }^{140}$

According to art. 37(B)(II), naturalized Mexicans lose their nationality by accepting foreign noble titles. This provision obviously lacks contemporary relevancy. This provision appears to contradict art. 12 of the Mexican Constitution, which states that titles of nobility granted by a foreign state do not have any consequences under Mexican law. ${ }^{147}$

It is of course obvious that all cited provisions are considerably too wide in view of art. 7(1)(d) ECN. Moreover, the above cited provisions of Belgium, France (at least art. 25), Ireland, Luxembourg, Mexico, Spain, and the UK discriminate against naturalized citizens, which constitutes a violation of art. 5(2) ECN. An application of art 23-7 F, 20(1)(c) G and 48 SWIT could in certain circumstances be possible under art. 7(1)(d) ECN. Austria was of the opinion - soundly, in my view - that the

${ }^{143}$ Art $25(\mathrm{c}, \mathrm{d}, \mathrm{e}, \mathrm{f})$ on the loss of Turkish nationality by persons who avoid satisfying military service in Turkey and live outside Turkey is applied frequently. In 1990: 855 persons; 1991: 948 persons; 1992

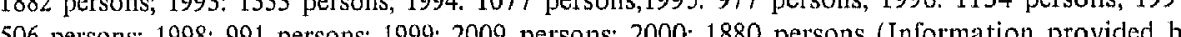
Sofrettin 1 198. 144 In case of war or emergency within one month

${ }^{145}$ See Trop v. Dulles, 356 U.S. 86 (1956); 239 F II 527; AJIL 1958, 777

${ }_{140} \mathrm{Sec} .340$ INA, see above in parts $I(F)$ and II $(B)$.

${ }^{147}$ See Philippe Couvreur, Mexique, Nr. 66, in: Charles L. Closset/Michel J. Verwilghen, Jurisclasseur Nationalité, Paris, loose-leaf edition. 
above-mentioned par. 33 of the Austrian Nationality Act, according to which an Austrian in the service of a foreign country shall be deprived of nationality if he severely damages the interests or the reputation of Austria by his behavior, had a wider application than is permissible under art. $7(1)(d)$, which covers only acts "seriously prejudicial to the vital interests" of Austria.

\section{Statelessness}

Art. 7(3) ECN does not allow the deprivation of a nationality because of behavior which constitutes a danger for the vital interests of the state if the consequence would be statelessness of the person involved. Nevertheless, we can observe that some of the provisions described above allow deprivation even if statelessness is
possible.

\section{Trends}

Art. 7(1)(d) ECN shows, in combination with the cited national provisions, certain tendencies. First, only behavior seriously prejudicial to vital interests of the state can legitimate deprivation of nationality. Second, deprivation of nationality on this ground shall not cause statelessness. And importantly, all citizens have to be treated equally. It is not acceptable that only naturalized citizens can be deprived of thei nationality because of their behavior (art. 5(2) ECN).

Finally, one should realize that several countries studied in this paper do not accept serious prejudicial behavior as a ground for loss of nationality at all countries); six countries apply this ground for loss exclusively to and which is not acceptable under art 5(2) ECN. On Autusive Switzerland, and Switzerland, and Turkey apply this ground also to natural born citizens.

\section{LACK OF A GENUINE LINK $^{148}$}

\section{A. General Remarks: Treaties}

Art. 7(1)(e) ECN allows for loss of nationality because of a lack of a genuine link between the state party and a national habitually living abroad. The explanatory report on the ECN declares: "It is presumed that the State concerned will have taken

\section{${ }^{148}$ Gerard-René}

ground for loss has at, Staatsangehbrigkeitsrecht im Wandel, o.c., 290-295. In some conntries, this of nationality in case of "établissement fait en pays étranger, sans esprit do which provided for loss claxified that having a commercial establishment in another country was not enourgh to The provision the intent to return was lacking ("Les établissements de commerce ne pouvront jamais être considers commo ayant ete faits sans esprit de retour."). See for Luxembourg: Schockweiler, in Closset/ Verwilghen, Nr. 82. Compare as well for Austria, art. $32 \mathrm{ABGB}$ (in force until 1925): Germuny, par. 21 and 112 Act 1870; art. 26 Ce 1889 (in force until 1954). art. 10(3) Act 1850, and for Spain, art. 4(4) all reasonable measures to ensure that this information is communicated to the persons concerned." Furthermore the report underscores:

Possible evidence of the lack of a genuine link may in particular be the omission of one of the following steps taken with the competent authorities of the State Party concerned: $i$ registration; ii application for identity or travel documents; iii. declaration expressing the desire to conserve the nationality of the State Party.

The explanatory report continues with the remark that:

Sub-paragraph e also has to be interpreted in the light of:

- the definition of nationality as a legal bond between an individual and a State (Article 2, paragraph a),

the prohibition of the arbitrary deprivation of nationality (Article 4, paragraph c),

- the possibility of excluding children born outside the territory from acquiring the nationality ex lege of one parent (Article 6, paragraph 1.a) and

the right to an administrative or judicial review (Article 12).

Obviously, administrative or judicial review of the decision that no genuine link exists must be possible. That fact should perhaps imply that a judge could come to the conclusion that there is still a genuine link even though the formal criteria of the nationality legislation of the country involved are fulfilled.

The possibility of loss of nationality because of continuous residence abroad is also mentioned in art. 7 of the Convention on the Reduction of Statelessness of 1961:

3. Subject to the provisions of paragraphs 4 and 5 of this Article, a national of a Contracting State shall not lose his nationality, so as to become stateless, on the ground of departure, residence abroad, failure to register or on any similar ground.

4. A naturalized person may lose his nationality on account of residence abroad for a period, not less than seven consecutive years, specified by the law of the Contracting State concerned if he fails to declare to the appropriate authority his intention to retain his nationality.

What is important in this context is a resolution accepted as an annex to the Convention on the Reduction of Statelessness 1961, which reads as follows:

(III) The Conference recommends Contracting States making the retention of nationality by their nationals abroad subject to a declaration or registration to take all possible steps to ensure that such persons are informed in time of the formalities and time limits to be observed if they are to retain their nationality.

\section{B. National Provisions}

The nationality laws of several countries contain provisions that make possible the loss of nationality because of a continuous residence abroad. The details of these regulations vary considerably. 
In Denmark, art. 8(1) provides that any person who is born abroad and has never lived in Denmark, nor stayed there under conditions indicating an interdependence ("samhørighed") $)^{149}$ with Denmark, shall lose his Danish citizenship upon attaining the age of 22. The Minister for the Interior or anyone so authorized by him may, however, on application submitted to him before this time, permit the citizenship to be retained. ${ }^{150}$

Almost identical provisions can be found in the other Scandinavian countries (art. 86 FIN, 8 IC, ${ }^{151} 8$ N, 8 SW; see also art. 14 SW bill 2000:147). In Finland there have been some problems of interpretation of this provision as to whether an application must be submitted to the president even in cases when it is obvious that the person in question has not lost his Finnish nationality because of a period of residence in Finland. It was decided, that in such a case the applicant may be notified that he will not lose the Finnish nationality. ${ }^{152}$

The Scandinavian nationality statutes have separate provisions for loss of their nationality in case of a national who also possesses the nationality of another Scandinavian country with which a special treaty is concluded, if the person involved lives, after having attained the age of majority, during a period of five consecutive years in the country of his other nationality. If I see it correctly, these provisions do not have any practical relevance, because the treaties involved are not (yet) in force. ${ }^{153}$

Whereas in the Scandinavian countries an individual born abroad has to apply for an authorization to retain his nationality in the case of permanent residence abroad, Belgium has chosen a different construction: the individual involved has to make a declaration of continuation of nationality. Art. $22(1)(5) \mathrm{B}^{154}$ provides that, since 1985 , Belgian nationality is lost by a Belgian who was born abroad and outside

${ }^{149}$ Henrik Zahle, Danish nationality law, in Nascimbene, 194: one year of residence in Denmark is enough. CC. as well Allan Rozas/ Markku Suksi, 292, note 54.

${ }_{150}$ Ingrid Bellender, 658, note 38 states that for Sweden this consent is normally granted. In the period 1996-1999 the authorization to retain Swedish nationality has been granted in 753 cases $(1996=184$ $1997=191 ; 1998=188$ and $1999=190$ ). Information given by Bo Lundberg, Migrationsverket in letter of 6 September 2000 .

151 Jón Thors, Dóms- og Kirkjumálar Áduneytid (Ministry of Justice and Ecclesiastical Affáirs), Reykjavik in a letter of 17 November 2000 underscores that most of the individuals falling under the rule of art. 8 have been in contact with Tceland to such an extent that they fulfill the condition of having either been domiciled in the country or resided in Iceland for any purpose which could be interpreted as indicating a desire to be an Icelandic citizen and therefore a permit granted by the president to retain the citizenship is not needed. Such permits are however granted now and then, but less than once a year. No statistical information is available.

2 Opinion delivered 19 October 1990 (D.No. 32/20/89) of the Chancellor of Justice. See Allan Rozas/ Markku Suksi, in Nascimbene, 292.

See for Denmark: Henrik Zahle, in Nacimbene, 196; for Finland: Allan Rozas/ Markku Suksi Nascimbene, 292; for Sweden Ingrid Bellander, Suède, Nr, 84, in: Charles L. Closset/ Michel J. Verwilghen, Jurisclasseur Nationalite, Paris, loose-leaf edition

the provision was included in Belgin nationaty taw in 1985, in Nascimbene 146 mention that Tetherlands See Doc Parl Chamber ses. ord. 1983/84, 21, D. 122 the former Belgian colonies if a) he had his main permanent residence abroad between his 18th and 28th birthdays; b) he is not fulfilling a function in service of the Belgian government or acquired with the intervention of the Belgian government and is not employed by a Belgian legal person; and c) he did not declare before his 28 birthday that he wants to keep his Belgian nationality. On the day of such a declaration, a new period of ten years starts to run. The provision does not apply declar lon, a new period of ( 1985 and does not apply at all to Belgian nationals who had already reached the age of majority. ${ }^{155}$ If a national did not make the required declaration of continuation because of an "act of God" ("cas fortuit ou de force majeure"), he can ask permission from the court to submit the declaration at a later moment. ${ }^{156}$ It is remarkable that the Belgian provision expressly makes an exception for persons living abroad in the service of Belgium or as an employee of a Belgian company. ${ }^{157}$

Lanc. 1987 a very similar provision (art. 25(8) L), but the Luxembourg has had since 10 residence abroad is 20 years. Living abroad as an required period of permanent residence abroad is 20 years. Living abroad as an employee of a Luxembourg company does not save one's Luxembourg nationality if one forgets to lodge a declaration of continuation. If the person involved or his spouse lives abroad in service of the State of Luxembourg or of an international organization, this ground for loss does not apply. In contrast to the Belgian regulation, the declaration of continuation has to be repeated in Luxembourg at least every 20 years. The provision does not apply if statelessness would be the every 20 years.

The Netherlands follows similar lines. Art. 15(c) provides that a person who is of full age shall lose his Netherlands nationality if, after coming of age, he has his place of residence for a continuous period of ten years outside the Netherlands, the Netherlands Antilles, or Aruba in the country of his birth and of which he is a national other than in the service of the Netherlands or the Netherlands Antilles or of an international Kingdom is represented, or as the of an in or a person in such sevice. In contrat with Belgium and Luxembourg there spouse of a peson in such service in cons exists no possibility of preventing the loss by lodging a declaration to the competent authorities stating that one wants to retain one's Netherlands nationality. ${ }^{159}$

${ }_{155}$ See Closset, Nr. 154, with reference to Circ. 17 December 1984, Aff. étrang.

${ }^{156}$ Closset, Nr. 154

Regrettably no statistical data are available on the application of this provision. Information provided Jan Van De Velde, Advisor General, Ministry of Foreign AfTairs, Brussels, in a letter of 13 December 2000.

158 Statistical data on the application of this provision are not available, because of the fact that this ground for loss was only introduced by art. 46 of the Statute of 11 December 1986, modifying the Luxembourg nationality act (in force on 1 January 1987). The first cases of loss based on this ground

159 will occur on 1 January 2007. Information provided by M. A. Kutl 1985 (sce art.7(3) Act 1892). Until

1910, the provision of art 7(3) could cause statelessness. 
Moreover, no possibility exists for the authorities to correct the loss in cases where the person involved still has evident ties with the Netherlands. The loss happens $e x$ lege. Based on the above-cited explanatory report on art. 7(1)(e) ECN, it is doubtful whether the legal construction of art. 15(c) NL conforms with the Convention. If a Netherlands national who fulfills the requirements of art. 15 (c) is registered at the Embassy, is in possession of a Netherlands passport, and expresses his desire to retain Netherlands nationality, he nevertheless loses this nationality ex lege, which s, in my opinion, a violation of the mportant modifiament, Netherlands nationality will no longer be lost by a person who is in possession of a Netherlands passport not older than ten years or a certificate of possession of Netherlands nationality, which is not older than ten years. After that modification, art. 15(c) will be in conformity with the new Convention.

In France a different construction is used (art. 23-6 F). The loss of French nationality can be established ("constatée") by a judgment if the person involved acquired French nationality by descent (more precisely: "français d'origine par filiation"), never possessed the "status of a French national" ("possession d'état") and never had his habitual residence in France. Additional conditions are that the ancestors of the person in question neither had the "status of a French national" nor lived in France for the last fifty years. The judgment also has to indicate at which moment the French nationality was lost. It is possible to decide that the nationality was already lost by the parent(s) of the person involved and that this person therefore never possessed French nationality. ${ }^{160}$ Art. 23-6 is only used in exceptional cases. ${ }^{161}$ Art $23-7 \mathrm{~F}$ was already mentioned, according to which a French national who behaves himself as a nati French nationality by a "décret" in conformity with an opinion given by the Conseil d'État.

In Greece a possibility existed until June 1998 to deprive a Greek national, of non-Greek ethnic descent, of Greek nationality because of permanent residence abroad. Art. 19 provided that a national of non-Greek ethnicity who left the territory of Greece without any intention of returning may lose Greek citizenship. The same applied for a person of non-Greek ethnic descent who was born and resided permanently in another country. The decision on the loss of Greek tor made by the (t) Interior in conformity with th for citizenship. ${ }^{162}$ Art. 19 was abolished on 25 June $1998 .{ }^{163}$

${ }_{161}^{160}$ On this provision see Paul Lagarde, in Nascimbene, 323, 324.

In an E-mail of 4 January 2001 Paul Lagarde mentions that the only case he knows from the last drot international priv - 1987, 93 (uibual de Grande Instance of 18 October 1985, Revue critique de drot international priv - 1987, 93 (with, comment of Ligarde).

See on this old provision Anastasian Grammaticaki-Alexiou, in Nascimbene, 408. De Brabanderesince 11 June 1975 because it violates art. 4(3) of the Greek Constitution, where it is non mextistent "Greek citizens are those who possess the qualifications specified by the law. No one shall be deprived of his citizenship save in the case of persons acquiring by their own free will another citizenship or
In Ireland a regulation providing for loss of Irish nationality because of continuous residence abroad applies exclusively to naturalized citizens. Sec. 19(1)(c) provides: ${ }^{164}$ The Minister [of Justice] may revoke a certificate of naturalization if he is satisfied ... (c) that (except in the case of a certificate of naturalization which is issued to a person of Irish descent or associations) the person to whom it is granted has been ordinarily resident outside Ireland (otherwise than in the public service ${ }^{165}$ ) for a continuous period of seven years and without reasonable excuse has not during that period registered annually in the prescribed manner his name and a declaration of his intention to retain Irish citizenship with a diplomatic mission or consular office or with the Minister

Some similarities with the decribed provisions exist in Spain art. 24, according to which Spaniards of full age ("emancipados"), ${ }^{166}$ who have their habitual residence abroad, lose Spanish nationality if they exclusively use their other nationality and if that mation altributed to them before they reached full age (emancipation).

The Scandinavian, Belgian, French, Lux

(1) (e) EN An authoizalon of continu are, as such, not problematic in view of art. 7(1)(e) ECN. An authorization of continuation can be given, and an individual can make a declaration of continuation himself Alternatively, the authorities will decide in the case involved whether a relevant link to the country of origin still exists. The corresponding provision still in force in the Netherlands (art. 15(c)) gives problems, because of a lack of attention to the concrete circumstances of the person involved.

The Irish provision is, in my opinion, very problematic. The Irish regulation The Irish provision is, in my opinion, very problable in view of art. 5(2) ECN. applies only to naturalized citizens, which is not acceptable in view or art. It has to be stressed that the Irish provision has an ethnic dimension as well, because the provision does not apply to persor

unacceptable under art. 5(1) ECN. .

joining a service in another country which is contrary to the national interests, in accordance with the conditions and procedure laid down by the law in detail

163 Act 2623/1998. The abolition did not have retroactive effect. See Zoe Papassiopi-Passia, The Greek Nationality Law in a Nutshell, Revue Hellénique de Droit International 1998, 513, 514, who mentions that the Constitution of the 1975 provided that art. 19 would remain in force until abolished by law, in spite of the obvious unconstitutionality of the provision.

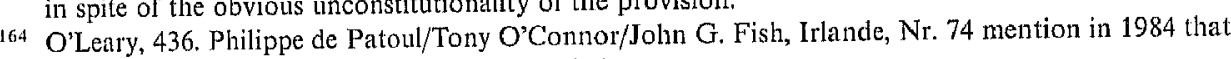
since 1956 this provision has never been applied.

${ }_{165} \mathrm{Sec}, 2$ sta that "public enve" when used in relation to the employment of a person, refers to employment in the service of the sovernment, whether or not in the civil service, or in the service of my public corportic funds or in respect of which a Minister of State is responsible.

166 José Carlos Fernandez Rozas/ Aurelia Alvarez Rodriguez, in Nascimbene, 235, mention that in their opinion this ground of loss exclusively applies if the persons involved became "emancipado" after the Act of 1990 modifying the nationality provisions of the Codigo civil came in force. 
February 1977 or his birth outside of Canada (and therefore his Canadian citizenship) was registered after that date, loses Canadian citizenship on attaining the age of 28 unless the person applies to retain citizenship and has resided in Canada for at least 1095 days during the six years before so applying. ${ }^{167}$

In Mexico naturalized citizens can lose their nationality after having resided for five years abroad ("por residir durante cinco años continuos en el extranjero") (art. 37(B)(II)).

In Turkey deprivation of nationality is possible if a person acquired a foreign nationality and lived abroad continuously for a period longer than seven years without formal contact with Turkey and without the presence of indications of a link with Turkey (art. 25(h))

Switzerland introduced loss of Swiss nationality because of permanent residence abroad in 1952. ${ }^{168}$ Art. 10(1) provides that a child of a Swiss parent loses Swis nationality at his 22 nd birthday if that person a) was born abroad, b) also possesse another nationality, and c) was not registered watil then at the Swiss a pous (more precisely: "wennes nicht bis dahin einer schn (more precisely: "wenn es nicht bis dahin einer schweizerischen Behörde im Ausland oder Inland gemeldet worden ist oder sich selber gemeldet hat oder schriftlich erklärt, das Schweizer Bürgerrecht beibehalten zu wollen")

The United States formerly provided for possible revocation of a naturalization decree if the naturalized citizen moved within five years after his naturalization to another country. That provision was repealed in $1994{ }^{169}$

\section{Cases of Non-Acquisition iure sanguinis in Case of Being Born Abroad}

Art. 7(1)(e) ECN allows for deprivation of nationality based on the lack of a genuine link because it is acceptable that a state wants to avoid the transmission of its nationality to generations born abroad without any limitation. Another possibility for a legislator is of course to limit the possibility of transmission of the nationality by parents to their children in case of birth abroad. In order to allow an evaluation of loss of nationality because of lack of a genuine link, one has to pay attention well to cases of limitation of transmission of nationality in case of birth abroad.

Several of the countries studied in this contribution provide for such limitation on the transmission of their nationality in case of birth abroad.

According to art. $8 \mathrm{~B}$, Belgian nationality is acquired by every child of a Belgian parent born in Belgium, but by a child of a Belgian parent born abroad only if one of three different conditions is fulfilled: (a) the parent was born in Belgium or in territories under Belgian administration ("dans des territoires soumis a la souverineté belge ou confiés à l'administration de la Belgique"): ${ }^{170}$ (b) within five years after

\section{${ }_{168}^{167}$ Compare sec, 3(1)(b) Citizenship Act,}

${ }^{168}$ See Pierre Corboz, Suisse, Nr. 81, 82, in: Charles L. Closset/ Michel J. Verwilghen, Jurisclasseur Nationalité, Paris, loose-leaf edition. Also R.Schrärer, REC, $359 \mathrm{fT}$

169 United States v. Banafsche, 616 F.2d 1143 (9th Cir. 1980).
170 Congo, Rwanda and Burundi. the birth of the child, the Belgian parent registers the child as a Belgian nationali: ${ }^{171}$ (c) the child is otherwise born stateless or loses his (other) nationality before his 18 th birthday ("ou ne conserve pas jusqu'à l'age de dix-huit ans ou son émancipation avant cet âge, une autre nationalité").

Since 1 January 2000, the German nationality act provides in par. $4(4)$ that German nationality will no longer be acquired by descent if a child of German parent(s) is born abroad after 31 December 1999 and has his habitual residence

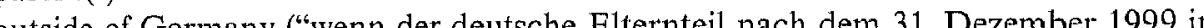
outside of Germany ("wer Ausland geboren wurde und dort seinen gewohnlichen Aufenthalt"). German nationality is nevertheless acquired if the child otherwise would be stateless. If the child does not acquire German nationality of the parent(s) ex lege because of the birth of two generations abroad, a parent can register the child as a German national within one year after the birth of the child. ${ }^{172}$

British nationality law contains a limitation of the transmission by descent in case of birth abrod as well. The relevant British provisions are quite complicated Sec of birth abroad as well. The relevant Bits the 1(1) GB provides that a person born in the United Kingdom shall be a Britis citizen if at the time of the birth his father or mother is (a) a British citizen; or (b) settled in the United Kingdom. Section 2 states, inter alia, that a person born outside the United Kingdom shall be a British citizen if at the time of the birth his fathe or mother (a) is a British citizen otherwise than by descent; ${ }^{173}$ or (b) is a British citizen and is serving outside the United Kingdom in British service, his or her recruitment for that service having taken place in the United Kingdom; or (c) is a British citizen and is serving outsic Community institution, his or her recruitment for that service having taken place in a country which at the time of the recruitment was a member of the Community.

Section 3 deals with the nationality status of, to put it briefly, the second generation born abroad. According to subsection 2 of section 3, a person born outside the United Kingdom shall be entitled, on an application for his registration as a British citizen made within a period of twelve months from the date of the birth, to be registered as such a citizen if the requirements specified in subsection (3) or, in the case of a peron born stateless, the requirements specified in paragraphs (a) and (b)

17 Regrettably no statistical data are available on the application of this privision. Information provided by Jan Van De Velde, Advisor General, Ministry of Foreign Affairs, Brussels, in a letter of 13 December 2000.

172 This limitation of the transmission of German nationality is completely new in German nationality law, but it will take some considerable time before this modification will have concrete results. The first children who will not acquire German nationality becanse or this tinive ar

Children of naturalized British citizen therefore always acquire British nationality in case of birth

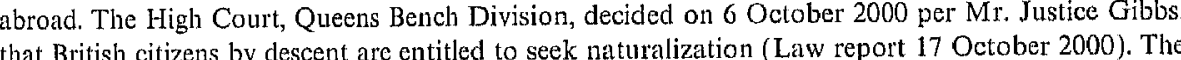
Home Secretary has lodged an appeal against the decision of the High Court. Information provided by Andrew Hirst, Policy Section, Immigration and Nationality Directorate, Home Ollice, in a letter of 6 February 200 
of that subsection, are fulfilled in the case of either that person's father or his mother ("the parent in question"). These requirements are:

(a) that the parent in question was a British citizen by descent at the time of the birth; and

(b) that the father or mother of the parent in question-

(i) was a British citizen otherwise than by descent at the time of the birth of the parent in question; or

(ii) became a British citizen otherwise than by descent at commencement, or would have become such a citizen otherwise than by descent commencement but for his or her death; and

(c) that, as regards some period of three years ending with a date not later than the date of the birth-

(i) the parent in question was in the United Kingdom at the beginning of that period; and

(ii) the number of days on which the parent in question was absent from the United Kingdom in that period does not exceed 270

Subsection 4 permits the Secretary of State to allow a later registration, by providing that "if in the special circumstances of any particular case the Secretny of State thinks fit, he may treat subsection (2) as if the reference to the Secretar were a reference to six years."

If a person is born abroad as a child of a British parent without acquiring British citizenship, he may acquire a right to registration if the conditions of subsection 5
are fulfilled:

(5) A person born outside the United Kingdom shall be entitled, on an application for his registration as a British citizen made while he is a minor, to be registered as such a citizen if the following requirements are satisfied, namely-

(a) that at the time of that person's birth his father or mother was a British citizen by descent; and

(b) subject to subsection (6), that that person and his father and mother were in the United Kingdom at the beginning of the period of three years ending with the date of the application and that, in the case of each of them, the number of days on which the person in question was absent from the United Kingdom in that period person in question was

(c) subject to subsection (6), that the consent of his father and mother to the registration has been signified in the prescribed manner.

Another country with a limitation of the transmission of nationality iure sanguinis in case of birth abroad is Portugal, where art. 1(1)(b) provides that the children of a Portuguese father or a Portuguese mother born abroad acquire Portuguese nationality by birth, if they declare that they want to be Portuguese or if they register the birth in a Portuguese civil register. ${ }^{174}$ If the parents reside abroad in the service of Portugal, their children acquire Portuguese nationality ex lege (art. 1(1)(a)).

Across the Atlantic Ocean limitations of the transmission of nationality by descent can also be found.

In Canada, sec. 4(1)(b) bill C-16 provides that a person born abroad as child of a Canadian parent acquires Canadian nationality unless the parent herself or himself was born outside of Canada as the child of a father or mother who acquired Canadian citizenship at birth outside of Canada from a Canadian parent. If the result would be statelessness, sec. 11 bill C-16 gives the Minister the power to grant result would be statelessness, sec. 11 bill $\mathrm{C}-16$ gives the Minister the power
Canadian citizenship to such a person if certain conditions are fulfilled. ${ }^{175}$

Canadian citizenship to such a person if certain conditions are fulfilled. ${ }^{175}$
In Mexico art. 30(II) and (III) of the Constitution provides, since 20 March 1997, a severe limitation of the transmission of Mexican nationality in case of birth abroad. Mexican nationality is exclusively acquired by children of a Mexican parent ${ }^{176}$ if the parent was born in Mexico or acquired Mexican nationality by naturalization.

In the United States, sec. 301 INA $^{177}$ provides that American citizenship is acquired at birth by the following principal classes of persons:

(c) a person born outside of the United States and its outlying possessions of parents both of whom are citizens of the United States and one of whom has had a residence in the United States or one of its outlying possessions, prior to the birth of such person;

(d) a person born outside of the United States and its outlying possessions of parents one of whom is a citizen of the United States who has been physically present in the United States or one of its outlying possessions for a continuous period of one year prior to the birth of such person, and the other of whom is a national, but not a citizen of the United States;

(g) a person born outside the geographical limits of the United States and its outlying possessions of parents one of whom is an alien, and the other a citizen of the United States who, prior to the birth of such person, was physically present in the United States or its outlying possessions for a period or periods totaling not less than five years, at least two of which were after attaining the age of fourteen years: Provided, That any periods of honorable service in the Armed Fores of the United Stales, or periods We of employment with the United States Government or with an international
organization ... by such citizen parent, or any periods during which such

174 Each year approximately 25,000 of these registrations take place. Information provided by Odete de Almeida Pereira da fonseca Jacinto, Director of the Conservatória dos Registros Centrais, Ministry Almeida Pereira da fonseca Jacinto, Director
of Justice, in a letter of 12 December 2000.

${ }_{175}$ Compare sec. 8 Citizenship Act.

170 The Mexican nationality of the mother can be transmitted to all her children born abroad since a modification of the Constitution of 26 December 1969.

1778 U.S.C. $\$ 1401$ 
citizen parent is physically present abroad as the dependent unmarried son or daughter and a member of the household of a person (A) honorably serving with the Armed Forces of the United States, or (B) employed by the United States Government or an international organization ... may be included in order to satisfy the physical-presence requirement of this paragraph. ..

D. Possible Complications Caused by European Community Law

Under very special circumstances it is possible that the loss of nationality of a Mner State of the European Union because of continuous residence abroad constitutes a violation of European Community law because of the free movement rights guaranteed by the EC Treaty. A violation of the right of free movement within rights guaranteed by the EC Treaty. A violation of the right of free movement within the European Union could exist, if a national of a Member State would lose his
nationality (and therefore the status of citizen of the Union) when he lives abroad in another member state during a certain period. ${ }^{178}$ The use of the right of free movement guaranteed by the $\mathrm{EC}$ treaty in combination with such a regulation would cause the loss of the nationality and therefore, in some cases, the loss of the status of European citizen. In my opinion such a regulation cannot be accepted by of European citizen

Let us assume that the Netherlands would amend the provision of art. 15(c) of its Nationality Act in the following sense: Netherlands nationality will be lost by any Netherlands national who also possesses another nationality and lives, after havin reached the age of majority, for a continuous period of ten years outside the Netherlands, the Netherlands Antilles or Aruba in a foreign country, other than in service of the Netherlands or the Netherlands Antilles, or of an international organization in which the Kingdom is represented, or as the spouse of a person in service. In some cases the application of this rule would constitute a violation of Community law. That would be the case if somebody were to possess the nationality of the Netherlands and of a non-EU state. After having lived for a period of ten years in, e.g., Germany, he would lose Netherlands nationality and therefore the status of European citizen. This result is especially unacceptable in cases where the citizen involved is not able to renounce his non-EU nationality due to the domestic nationality rules of the non-EU state involved 179

\section{E. Some Exceptional Provisions}

The above cited sec. 19(1)(d) IRL, according to which the Minister of Justice may revoke a certificate of naturalization if he is satisfied that the person to whom it is

178 Similar hesitain

ane expressed by Siofra O'Leary, in Nascimbene, 436, footnote 59, on section 19(1) IRL.

Compare an amendment proposed in a bill, which was sent by the Netherlands governinent to the 25 February 1993. But as early as 16 September 1993 the government modified the new article: no loss of Netherlands nationality should occur if the person involved icsides granted is also, under the law of a country at war with the state, a citizen of that country, has a remote relationship with loss of nationality because of lack of genuine link. The provision is nevertheless unacceptable, because naturalized citizen are discriminated against by this provision (see art. 5(2) ECN).

In this context attention has to be paid as well to par. 29 of the recently modified German Nationality Act. This provision provides that a child of foreign parents born in Germany who has acquired German nationality iure soli because of the new par 4(3) or by naturalization based on par. 40b, and who also possesses a foreign par. $4(3)$ or bas to lodge a written declaration with the German authorities stating nationality, has to lodge a written declaration with the German authorities stating whether he wants to retain the German or the foreign nationality. If he chooses in before the 23rd birthday, German nationality is lost as well. Before the 21st birthday an application can be made to receive a permit of retention of the foreign nationality in addition to German nationality.

Art 25(7) of the Luxembourg Nationality Act provides that a Luxembourg Ational who is older than 18 years and also possesses a foreign nationality loses Luxembourg nationality if he made a declaration to the foreign authorities in order to maintain that other nationality ("qui a fait, devant l'autorité étrangère compétente, une déclaration en vue de la conserver"). The same applies to a Luxembourg national who did not renounce his foreign nationality within two years after the Luxembourg authorities gave an order to do so ("qui, nonobstant une mise en demeure à lui dressé par le ministre de la justice, n'a pas, dans un délai de deux ans à partir de special declaration that he wants to maintain Luxembourg nationality in case a renunciation of the foreign nationality is not possible ("qui n'a pas déclaré, ... vouloir conserver la nationaté luxembourgeoise au cas où la renonciation à la nationalité étrangère n'est pas possible")..$^{180}$

In Mexico art. 37 provides that a naturalized citizen loses his nationality not only by voluntary acquisition of a foreign nationality, but also by being mentioned in a public document as a fore titles which imply a submission to a foreign state ("por hacerse pasar en cualquier titles which imply a submission to a foreign state ("por hacerse pasar en cualquier

instrumento publico como extranjero, por usar un pasaporte extranjero, o por
aceptar o usar titulos nobiliarios que impliquen sumision a un estado extranjero").

\section{F. Trends}

It is remarkable that an increasing number of countries provide for loss of nationality in case of birth abroad if the nationals involved live permanently abroad. On the

in by having a Netherlands passport or a certificate of possession of Netherlands nationality.

180 This ground for loss is inspired by Resolution (77)13 of the Council of Europe. See Fernan Schockweiler, in Closset/ Verwilghen, Nr. 81. 
one hand, this approach is used by countries which already try to avoid as often as possible cases of dual nationality, for example, by providing that voluntary acquisition of a foreign nationality is a ground for loss of their nationality (see Belgium, Luxembourg, Netherlands, and Scandinavian countries). On the other hand, this construction is also used as an alternative, instead of specifying that voluntary acquisition is a ground for loss of the original nationality. That is for example the case in Switzerland.

In particular, the explanatory memorandum of the ECN underscored that this ground for loss should be applied in a manner that permits all relevant circumstances to be taken into account. Therefore individuals must have the possibility of making a declaration of retention or of lodging an application for permission of the government to retain the nationality involved.

\section{LOSS OF FAMILY RELATIONSHIP ${ }^{18}$}

A. General Remarks: Treaties

According to art. 7(1)(f) ECN, loss of nationality is acceptable where it is established during the minority of the child that the preconditions laid down by internal law which led to the ex lege acquisition of the nationality of the state party are no longer fulfilled. The most important example of this category is loss of nationality because of the fact that the family relationship that led to the acquisition of the nationality iure sanguinis is lost

\section{B. National Provisions}

An example of a regulation of loss of nationality because of loss of the relevant family relationship is art. 14(1) NL, according to which Netherlands nationality may be lost through cessation of the family law relationship from which Netherlands nationality is derived. This provision does not apply if it would lead to statelessness. The loss provided for by art. 14(1) NL is not restricted to cases where the family relationship ceases during the infancy of the person involved. That is obviously not in conformity with art. 7(1)(f) ECN. Bill 25891 (R 1609) therefore proposes restricting art. 14 to minors. ${ }^{182}$

In only a few other countries a special provision in respect of this ground for loss can be found. This is the case in Belgium ${ }^{183}$ and Luxembourg $(8(4) B ; 25(5) L)^{184}$

${ }^{181}$ Gerard-René de Groot, Staatsangehörigkeitsrecht im Wandel, o.c., 301-303.

${ }_{183}$ The proposed modification will have retroactivity to 1 January 1985.

183 If a child loses Belgian nationality because the fomily jalationship with a Belginn part is and before he reaches the age of 18 and the consequence is statelessness, Belgian be granted to the child on the basis of art. 10B, if the child was born, Belgian nationality may again provided by Jan Yan De Velde, Advisor General, Ministry of Foreign Affirs. Bussels in a leter or

13 December 2000.

${ }^{184}$ Fernand Schockweiler, in Nascimbene, 517
In both countries this ground for loss is restricted to cases where the relevant family relationship is lost before the majority of the child involved. In France art. 21-1 Cc is (a contrario) interpreted in the same way. ${ }^{185}$

In Switzerland, art. 8 (introduced in 1990$)^{186}$ provides that the loss of the family relationship which was the basis for the acquisition of nationality entails the loss of Swiss nationality if this does not cause statelessness. ("Wird das Kindesverhältnis zum Elternteil, der dem Kind das Schweizer Bürgerrecht vermittelt hat, aufgehoben, so verliert das Kind das Schweizer Bürgerrecht, sofern es dadurch nicht statenlos wird.")

In several other countries no special provision can be found, but that does not imply that the nationality is retained if the relevant family relationship is lost. From the competent Swedish authorities I received the information that if a child has acquired the Swedish nationality of the "father" iure sanguinis and the man thereafter declares himself not to be the father of the child, it will be considered that the child never acquired Swedish nationality. This is not based on any provision, but is a consequence of the fact that - judged in retrospect - the man has never been the father of the child. ${ }^{187}$ In case of the denial of paternity of a Turkish father, the child of a foreign mother loses Turkish nationality unless the child would become stateless. ${ }^{188}$ The Icelandic authorities mentioned that the Icelandic Nationality Act does not give any answer to the question whether loss of family relationship can cause loss of Icelandic nationality, but underscored that they had not yet encountered this type of case. ${ }^{189}$

In this context attention has to be paid to a reservation made by Austria on the occasion of its ratification of the European Convention on Nationality concerning art. 7(1)(f):

Austria declares to retain the right to deprive a national of its nationality whenever it has been ascertained that the conditions leading to the acquisition of nationality ex lege, as defined by its internal law, are not fulfilled any more.

Obviously Austria wants to preserve the possiblity that in a case where the conditions leading to the acquisition of nationality are no longer fulfilled, even after the person involved attained the age of majority, Austrian nationality may be lost as well

185 Information of Paul Lagarde in a E-mail of 14 January 2001.

${ }^{866}$ See also Botschant 26 August 1987 mentioned in Pierre Corboz, Stiisse, Nr. 77.

Information received from Bo Lundberg, Migrationsverket, in a letter or 6 September 2000. A similar answer was received from Denmark (Niels Beckman, Naturalization Division, Ministry of Justice, in a letter 14 December 2000). Beckman mentions also, that if the consequence is statelessness, the child will be naturalized as soon as possible.

8 Information provided by Sadrettin Karahocagyll, Turkish Interior Ministry (The General Directorate of Civil Status and Nationality Issues; Head of Nationality Department) in an e-mail of 23 October

Jón Thors, Dóms- og Kirkjumálar Áduneytid (Ministry of Justice and Ecclesiastical Affairs), Reykjavik in a letter of 17 November 2000. 
Furthermore, in Italy art. 3(3) provides for loss of Italian nationality because of a very special case of loss of a family relationship. ${ }^{190}$ When an adoption is revoked because of the criminal behavior of the adopted child against the adoptive parents, the adopted child loses Italian citizenship if he possesses another citizenship or he regains the prior citizenship. In other cases of revocation of the adoption, the adopted child maintains Italian citizenship. Nevertheless, if revocation occurs when the adopted child is of full age, the latter will be entitled to renounce Italian citizentu within one year after the revocation itself, if he possesses another citizenship or he regains it. Although the situation regulated by art. 3(3) is a tragic one, the loss of
Italian nationality in the cases mentioned is not covered by art. 7(1)(f) ECN if the adopted person involved has already reached the age of majority.

Finally art. $14 \mathrm{MOL}$ provides that if the adoption of a stateless or foreign child is declared null and void, the child is considered never to have acquired the nationality of Moldova, if he has his lawful and habitual residence abroad or if he leaves ${ }^{191}$ the country for a permanent residence abroad.

\section{Difficulties}

Loss of nationality because of loss of the family relationship which constituted the basis for the possession of nationality is, as such, acceptable. But a limitation on this ground of loss is desirable. It is, however, questionable whether this limitation should be the age of majority. A much shorter limitation period of, for example, ten years would be preferable. Furthermore, it is remarkable that some countries apply this
ground for loss without a clear legal basis. If applicable, this ground of loss should ground for loss without a clear legal
be enacted in a statutory provision.

\section{ADOPTION}

A. General Remarks: Treaties

According to art. $7(1)(\mathrm{g}) \mathrm{ECN}$ a nationality act may provide that the nationality is lost by the adoption of children if the nationality of the adopting parents is acquired. A provision on the consequences of an adoption for the nationality of the adopted child could already be found in art. 17 of the Convention on Certain Question relating to the Conflict of Nationality Laws concluded in The Hague in 1930:

If the law of a State recognises that its nationality may be lost as the result of adoption, this loss shall be conditional upon the acquisition by the person adopted of the nationality of the person by whom he is adopted, under the law

${ }_{191}^{190}$ Stefania Bariatti, in Nascimbene, 485.

${ }^{191}$ The provision does not mention whether this also applies if the child only leaves the country affer a considerable period elapses following the annulment of the adoption. A limitation of this ground for loss is certainly necessaty. of the State of which the latter is a national relating to the effect of adoption upon nationality.

This principle was contained as well in art. 5(1) of the 1961 Statelessness Convention

If the law of a Contracting State entails loss of nationality as a consequence of any change in the personal status of a person such as marriage, termination of marriage, legitimation, recognition or adoption, such loss shall be conditional upon possession or acquisition of another nationality.

Reference has to be made as well to art. 11(2) of the European Convention on the Adoption of Children, concluded in Strasbourg on 24 April 1967. ${ }^{192}$

A loss of nationality which could result from an adoption shall be conditional upon possession or acquisition of another nationality.

\section{B. National Provisions}

In some countries, adoption of a child by foreigners is a ground for loss of nationality, provided that the child involved acquires the nationality of the adoptive parents by the adoption or already possesses this nationality. This is, for example the case in the Netherlands, where art. 16(1)(a) deals with this ground of loss. The same applies the Netherlands, where art. 16(1)(a) deals with this ground of loss. The same applies
for Belgium in art. 22(1)(4), ${ }^{193}$ Luxembourg in art. 25(4), and Switzerland in art. $8 \mathrm{a}(1)$.

Art. 27 of the German nationality act provides (since 1977), that a German lose his citizenship because of adoption by a foreigner if the adoption is regarded as valid under German law and if the German receives the citizenship of the person adopting him. The citizenship is not lost if the German remains related to a German parent. The acquisition of the The acquistion of he foreign nationality must occur ex lege by the adoption. If the foreign nationality is acquired by declaration of option lodged after the adoption, art. 27 does not apply. ${ }^{194}$ The loss extends to the minor offspring of the adopted German, if he has sole parental custody and if the acquisition of the new citizenship also extends to the offspring.

In some other countries, adoption by foreigners does not have consequences for the possession of the nationality by the child. This is, for example, the case in Mexico, we 30 (1) Ley de where art. 30(1) Ley de sequences for the acquisition or loss of nationality ("la adopcion no entrana para e adoptado ni para el adoptante la adquisicion o perdida de la nacionalidad") Art. 27(2) of the Greek nationality act has to be mentioned in this context as well. According to that provision, adoption of a Greek national by foreigners does not

192 UNTS 634, 255

${ }^{103}$ Some critical remarks on these provisions are made by Gerard-René de Groot, geitsrecht in Wandel, o.c., 302

194 See Allo 27.1. 
automatically have consequences for the Greek nationality, but the adoptive parents may apply for the loss of Greek nationality on behalf of their adopted child if the child is still a minor and also has acquired the citizenship of the adoptive parent. This application will be accepted by the Minister of the Interior, who has to take into account the special circumstances of the case. ${ }^{195}$ The Minister mast ask the opinion of the council for citizenship. ${ }^{196}$

In most other countries loss of nationality by adoption is simply not mentioned at all in the nationality statutes. Adoption by a foreigner does not therentioned consequences for the nationality of the child. In some countries, courts have have expressly that other grounds for loss cannot be applied by ans, cove in cided minor was adopted by a foreigner (see Switzerland ${ }^{197}$ and USA $^{198}$ ) Moldova made a reservation in respect of art $7(1)(\mathrm{g})$ ECN with

content: "Concerning Article 7 paragect of art. 7(1) (g) ECN with the following content: "Concerning Article 7, paragraph 1, letter (g), the Republic of Moldova deciares its right to recognise and to conserve to the child who has the nationality of the Republic of Moldova, adopted abroad and who acquired the foreign nationaty in consequence of his adoption, the right to keep the nationality of the Republic Moldova." This reservation is in my opinion not necessary at does not want to use the possibility to provide loss of nations of a Moldovan child by foreigners. But no singe gre 7 of the Convention is manders. But no single ground for loss mentioned in art are allowed. The aim is mandatory. Art. 7 merely indicates which grounds for los adopted abroad aim of Moldova to allow multiple nationality for Moldovan children adopted abroad is also acceptable in view of art. 15 of the Convention, which allows determine in its internal law whether its nationals who aceure nationality of another state retain its nationality or lose it. ${ }^{199}$

\section{Difficulties}

"Full" adoption can at first sight be regarded as a special case of loss of family relationship. ${ }^{200}$ On the other hand, one can defend a different approach becanse of 195 De

Greek Nationality Law in a Nutsoulos-Spiliotopoulos, Nr. 100, and Zoe Papassiopi-Passia, The ${ }_{106}$ Until 1996, an application was not accepted if the adoped de Droit International 1998, 513.

or was being prosecuted for a crime or offence. However child was delaying his military obligations of minors (under the age of 18 years) is pernitted. Therefore the Act 2447/1996, only the adoption have any military obligation. See Bundesgericht 16 May 1975 ,

now regulated by art. 8a, already mentioned by Hecker, StAZ 1985, 160. In Switzerland this issue is See Hellmuth Hecker, Einftuß der Adoption aur

Darstellung der Regelungen in 175 Statten, StAZ 1985,153 . 163 gehörigkeit. Eine rechtsvergleichende 278 F, 174 (1922) and In re Voluntary Adoption of Minors, 226 , with references to Cabrillos v. Angel,

200 A full adoption art. $14 \mathrm{MOL}$ described above in part Vl(B).

and new logal relation a consequence that the legal relationship with the natural parents is dissolved provide, next to this full a between the child and the adoptive parents are created, Some countries tion simple), which does not dis (adoption pleniere), for the possibility of a "weak" adoption (adoption simple), which does not dissolve the legal relationship with the natural parents. the fact that the loss of the family relationship is in case of adoption a mere legal fiction and not the legal affirmation of a true situation -- as is the case with a denial of paternity or an annulment of a recognition. In a comparative perspective one can find both approaches adopted by various countries. It is worth noting that the ECN mentions loss of nationality by adoption in a separate proviso (lit. g) and not as a subcategory of loss of nationality because of a family relationship that was the basis of the acquisition of the nationality involved. If the full adoption is to be regarded as a different category, in my opinion it would be more logical not to provide for loss of nationality in that case.

\section{LOSS: CONSEQUENCES FOR CHILDREN}

A. General Remarks: Treaties

According to the second paragraph of art. 7 of the Convention, a State Party may provide for the loss of its nationality by children whose parents lose that nationality under paragraph 1 of art. 7, except in cases where the nationality is lost by the parent because of voluntary service in a foreign military force (sub c) or because of conduct seriously prejudicial to the vital interests of the state party (sub d). Children shall not lose that nationality, however, if one of the parents retains his or her nationality.

Some earlier treaty provisions also deal with the position of children whose parent(s) lose a certain nationality. Article 13 of the Nationality Convention of 1930 states:

In cases where minor children do not acquire the nationality of their parents as the result of the naturalisation of the latter, they shall retain their existing nationality.

In the 1961 Convention on the Reduction of Statelessness, two provisions dealt with this issue. Art. 5(1) provides that:

If the law of a Contracting State entails loss of nationality as a consequence of any change in the personal status of a person such as marriage, termination of marriage, legitimation, recognition or adoption, such loss shall be conditional upon possession or acquisition of another nationality.

In conformity with this principle, art. 6 continues:

If the law of a Contracting State provides for loss of its nationality by a person's spouse or children as a consequence of that person losing or being deprived of that nationality, such loss shall be conditional upon their possession or acquisition of another nationality.

Art. 1(3) of the 1963 Convention on Reduction of Cases of Multiple Nationality provides as follows for the nationality of children when a parent loses the nationality of a state party: 
consented to the declaration of will of his legal representative or a third person before the acquisition of the foreign nationality.

For Germany art. 19 determines that a legal representative may apply only with the consent of the guardianship court ("Vormundschaftsgericht") for the release ("Entalassung") from citizenship of a person under parental authority or guardianship. Along with the applicants, the state attorney's office is also entitled to appea against the decision of the court: the decision of the court of appeals is not subject to further appeals. The consent of the guardinship cout is not necer noject fother or the mother father or the mother applies for release for himself or herself and simultaneously applies for the release of the child by virtue of his or her parental authority and if the applicant is responsible for the custody of the child. If the duties of a special advisor ("Beistand") to the mother extend to the care of the child ("Sorge für die Person des Kindes"), the application of the mother for the child's release requires the consent of the special advisor.

In Poland art. 32(5)-(8) of the bill pending in the Sejm deals with the consequences of the loss of Polish nationality by a parent for his children. If both parents renounce their Polish nationality (with consent of the government) their minor children under their custody also lose Polish nationality. If only one parent renounces his nationality, the situation is more complicated. In that case the minor children under his custody also lose their nationality if one of the following conditions is fulfilled: (a) the other parent does not have custody over the children; (b) the other parent is not a Polish citizen; or (c) the other parent expressed before (he competent authoritis lis consen the other parent (see sub lit c) can be replaced by a decision of the competent Polish court. If a child already reached the age of 16 years, an additional condition for the extension of the loss of Polish nationality by renunciation is the consent of the child involved.

A completely different approach can be noticed in some other countries, where loss of nationality by a parent does not have consequences for the nationality of tis children. This is the case in Ireland, where sec. 22 provides:

1. The death of an Irish citizen shall not affect the citizenship of his or her surviving spouse or children.

2. Loss of Irish citizenship by a person shall not of itself affect the citizenship

of his or her spouse or children.

No effect of loss of nationality by a parent on the nationality position of children can also be observed in Mexico, where this is stated expressly in art. 29 Ley de nacionalidad ("La perdida de la nacionalidad mexicana por naturalizacion exclusivamente afectara a la persona sobre la cual recaiga la resolucion respectiva").

\section{Difficulties}

In some countries loss of nationality by the parents causes, in principle, loss of nationality by their minor children. In other countries this is often only the case if a court has given consent to this consequence. In still other countries, the loss by he pares children at all.

the parents does not influence the nationality positents occurred on a ground of loss Insofar as the loss of the nationality by the parents occured which was introduced because it was considered to be an indication of the loss of a genuine link between the parent and the state involved, it is not suprising that children are included in this loss. Where the parent does not have a relevant link with the state involved anymore, it is indeed less likely that his minor children will with the state situation is different, of course, develop relevant links wh the state if the parent lost his nationality as a sanction forial the interests of the state) service to another state; behavior seriously prejudicial to the ing

It is, however, a general problem whether a parent should have the power at all to determine directly or indirectly the nationality position of his children. The power of parents to represent their minor children is generally restricted in specific cases (such as making a last will or the sale of immovables owned by the child). (stch as traling ationality matters should perhaps be similarly restricted.

\section{RENUNCIATION OR RELEASE ${ }^{205}$}

A. General Remarks: Treaties

In a separate article the ECN deals with loss of nationality at the initiative of the individual. Art. 8(1) states that each state party shall permit its nationals to renounce their nationality, provided they do not thereby become stateless. An exception is their nationality, provided the do not have their habitual residence abroad.

The right given by art. 8 to renounce a nationality is expansive. The explanatory report states the following:

It is not acceptable under Article 8 to deny the renunciation of nationality merely hecouse perons habitually living in another State still have military merely because persons habitually living in an ivil or penal proceedings may obligations in the country of origin or because civil or penal procedings may be pending against a person in that country of origin. Civil or penal proceeding are independent of nationality and can proceed normally even if the person renounces his/her nationality of origin.

It was already mentioned above that art. 7(2) allows a state party to provide for the loss of nationality of children of a parent who has lost the nationality because (he loses of sub $c$ and d). Art. 8 does of a ground mentioned in art. Therefore I conclude that the Convention not contain a corren a nationality by a parent to have consequences does not allow the rentherlands for the nationality of his child Nerentands nationality by a parent also causes Nationality Act, a renunciation of Netherlands nationality by a

${ }^{205}$ Gerard-René de Groot, Staatsangehörigkeitsrecht im Wandel, o.c., 287-290. 
the loss of nationality by his minor children, except in the case where the other parent retains Netherlands nationality. This provision conflicts with the Convention. Therefore, upon ratifying the Europena Convention on Nationality the Netherlands made an 'interpretative declaration' (in fact a reservation) that makes it possible for the Netherlands to maintain this ground for loss. ${ }^{206}$ The declaration states:

With regard to Article 7, paragraph 2, of the Convention, the Kingdom of the Netherlands declares this provision to include the loss of the Dutch nationality by a child whose parents renounce the Dutch nationaliity as referred to in Article 8 of the Convention.

A completely different point is whether a state can allow renunciation of nationality if the consequence would be statelessness of the person involved. The Council of Europe's Recommendation 99(18), Part C, sub a and b, underscores that this would be unacceptable:

(a) Each State should ensure that the renunciation of its nationality will not ake place without the possession, actual acquisition or guarantee of acquisition of another nationatity. Where another nationality is not achuired tion of ans

possessed, States should provide that the renunciation is without effect.

(b) When a State requires persons to lose their previous nationality in order to acquire its nationality, this State should grant its nationality, even if the previous one is not immediately lost. The States concerned, if necessary, should agree on the modalities of the application of this provision.

In several other international instruments the right to renounce a nationality under certain circumstances was already stressed.

Art. 6 of the 1930 Hague Convention:

Without prejudice to the liberty of a State to accord wider rights to renounce its nationality, a person possessing two nationalities acquired without any voluntary act on his part may renounce one of them with the authorisation of the State whose nationality he desires to surrender: This authoristion be refused in the case of a pason wh be refused in the cise of a abroad, if the conditions laid down in the law of the State whose nationality he desires to surrender are satisfied."

Art. 12(2) of the 1930 Hague Convention:

The law of each State shall permit children of consuls de carrière, or of officials of foreign States charged with official missions by their Governments, to become divested, by repudiation or otherwise, of the nationality of the State in which

${ }^{206}$ Against the declaration, see the Permanent State Committce for Private International Law in an att. 22(1)(3) B and ant. 25(3) L they were born, in any case in which on birth they acquired dual nationality, provided that they retain the nationality of their parents.

Art. 7(1)(a) of the 1961 Convention on the Reduction of Statelessness:

If the law of a Contracting State permits renunciation of nationality, such renunciation shall not result in loss of nationality unless the person concerned possesses or acquires another nationality.

Art. 2 of the 1963 Convention on Reduction of Cases of Multiple Nationality:

1. A person who possesses the nationality of two or more Contracting Parties may renounce one or more of these nationalities, with the consent of the Contracting Party whose nationality he desires to renounce.

2. Such consent may not be withheld by the Contracting Party whose nationality a person of full age possesses ipso jure, provided that the said person has, for the past ten years, had his ordinary residence outside the territory of that Party and also provided that he has his ordinary residence in the territory Po the Party whose nationality he intends to retain Consent may likewise of the Party whose nationality he intends to retain. Consent nay likewise not be withheld by the Contracting Party in the case of minors who fulfill the conditions stipulated in the preceding paragraph, provided that thei national law allows them to give up their nationality by means of a simple declaration and provided also that they have been duly empowered or represented.

The 1977 Protocol Amending the Convention on the Reduction of Cases of Multiple Nationality changed the first sentence of art. 2(2) of the 1963 Convention to read as follows:

Such consent may not be withheld by the Contracting Party whose nationality a person of full age possesses ipso jure provided that the said person has his ordinary residence outside the territory of that Party.

Art. 3 of the 1963 Convention on Reduction of Cases of Multiple Nationality:

The Contracting Party whose nationality a person desires to renounce shall not require the payment of any special tax or charge in the event of such renunciation.

Council of Europe Resolution (77)13 on the Nationality of Children Born in Wedlock (adopted by the Committe of Ministers on 27 May 1977 at the 271st meeting of the Ministers' Deputies):

The Committee of Ministers recommends to governments of Member States:

2 to insert provisions in their internal legislation for the purpose of avoiding dual nationality resulting either directly or indirectly from descent or resulting from the place of birth.

To this end, they should, as minimum: 
a. give the right to their nationals having another nationality to renounce their nationality;

b. permit their nationals having another nationality to make a declaration in favor of their nationality; consequently, to insert provisions according to which their nationals having made a declaration in favor of another nationality which they possess equally, shall lose their nationality automatically.

They may in addition provide that their nationals of more than 22 years of age, possessing equally another nationality, and who have not made a declaration in favor of one or the other of their nationalities, may be summoned according to the previous paragraph to make a declaration within a time-limit which shall not be shorter than six months for one or the other nationality and that they, filing to do so within that time-imit shall automatcally lose the nationality of the state that summoned them.

\section{B. National Provisions}

Some states always allow a renunciation of their nationality if a national also possesses another nationality, even in case of residence within the country. This applies to Luxembourg (art. 25) and the Netherlands (art. 15(b)), ${ }^{207}$ for persons of full age, and for Portugal (art. 8).

In Belgium until 1991 the renunciation, for male persons, was generally subject to authorization by the King if the person involved still had military obligations (art. 22(2)) ${ }^{208}$ In contrast with Netherlands law, Belgium also allows renunciation if the national involved does not yet possess another nationality, but will acquire another nationality after the renunciation.

In several other states multiple nationals may renounce the nationality of the country involved if the national in question lives abroad (for a certain period). This applies for Austria (par. 37(2): ordinary residence outside the territory of the Republic for a continuous period of not less than five years), Italy (art. 11(1)), and Ireland (sec. 21(1)). Ireland makes an exception to this rule of minor importance in sec. 21(2), which specifies that an Irish citizen may not, except with the consent of the Minister, renounce Irish citizenship under this section during a time of war as defined in Article 28(3)(3) of the Irish Constitution.

A similar condition can be found in sec. 12(4) GB:

3. The Secretary of State may withhold registration of any declaration made in

207 Since 1985 , re

could renounce Netherlands nationt for evcry (dual) national. Since 1936, every national of full age had his residence listed (art 6 6(1) Civil code 1838. art 9 Act 1892)

8 Before 1985, Belginn nationility law allowed

14 Act 1909; art 4, 5, 18 auter and 21 Act 1932). Onion only in cases cxhaustively listed (art. 6, 12 On military service and the possibility of renunci- pursuance of this section if it is made during any war in which Her Majesty may be engaged in right of Her Majesty's government in the United Kingdom.

This condition is not in conformity with the ECN in cases where the national involved lives outside the UK.

In Germany par. 26 determines ${ }^{209}$ that a German may renounce his nationality if he also possesses another nationality. The renunciation must be declared in written form and requires the consent of the authorities. The consent may not be granted to: (a) government officials, judges, members of the armed services, and other persons appointed to public duties as long as their term of office is not terminated, except for volunteers; and (b) persons subject to military duty unless the Federal Minister of Defense has declared that he raises no objections against the release. If the person of Defense has declared that he raises no objections against the release. If the person involved has had permanent residence in a foreign country for at least ten years, and he has performed mandatory military service in one of the countries of which he is a citizen, the consent will be granted. In Germany, a release is also

Austria and Italy also allow, under certain circumstances, renunciation in case of Aidence within the country. Par. 37(1) A formulates the following conditions:

(2) no criminal procedure or execution of a criminal sentence is pending in Austria for an offence punishable with more than six months of imprisonment:

(3) a male person is not a member of the Federal Armed Forces; and

(a) has not yet passed the age of sixteen nor the age of thirty-six;

b) has fulfilled the regular military service or the regular civil service;

(c) has been found unfit for military service by the Recruiting Commission or has been declared permanently unfit for any kind of civil service by the competent administrative physician;

d) has been dispensed from recruitment to the Federal Army for reasons of mental illness or mental disorder; or

(e) has fulfilled the military obligations or in their place service obligations in another state of which he is a national and therefore is dispensed from regular military service or regular civil service on the basis of a bilateral agreement or of an international covenant.

Italy obviously also allows renunciation of Italian citizenship during residence in Italy for children whose adoption by Italian parents is revoked (art. 3(4)) and for children who acquired Italian nationality as a consequence of the acquisition or recovery of Italian nationality by a parent during their minority (art. 14(1)).

In Turkey, art. 20 prescribes the permission of the Council of Ministers for a the pull legal capacity and possesses or will acquire a foreign nationality. Art. 27 gives certain

209 According to Sturm, Nr. 118, these provisions do not play an important role in practice. 
categories of children the right to renounce Turkish citizenship within a period of two years before they reach the age of majority. Art. 28 gives women who acquired Turkish nationality by marriage the possiblity to renounce this nationality within three years after the dissolution of the marriage. ${ }^{210}$

In Canada sec. 15(1) bill C-16 $6^{211}$ states:

The Minister shall, on application, allow a citizen to renounce citizenship if the citizen

(a) is a citizen of a country other than Canada or, if the application is accepted, becomes a citizen of another country;

(b) is not a minor:

(c) is not prevented from understanding the significance of renouncing citizen-

ship by reason of the person having a mental disability; and

(d) resides outside Canada.

The second subsection makes it possible for the Minister to waive the conditions of (c) and (d) if "there are compassionate grounds for doing so."

The approach in France is completely different. Renunciation is possible only in the cases listed exhaustively in the French Code Civil (art. 18-1, 19-4, 20-2, 22-3, 23-5). In Spain also no general regulation of renunciation exists. Art. $23 \mathrm{SP}$ allows renunciation of Spanish nationality only in specific cases.

In the United States, renunciation of nationality is possible according to sec. 349 (a)(6) INA. The declaration of renunciation must be a voluntary action and the result of a free and "intelligent choice." 212

A variation on the renunciation of nationality is the release of a nationality by the state on application of an individual. ${ }^{213}$ This construction is, for example, practiced in Denmark (par. 9(1)):

1. The Minister for the Interior or anyone so authorised by him may release a person who is, or wants to become, a foreign national from such person's relations to Denmatk in terms of nationality. In the latter case such release shall take place on condition that the petitioner becomes a national of shall take place on condition that the
another country by a certain deadline.

Other Scandinavian countries have the same construction: 9 FIN, 9 gr. IC, $9 \mathrm{~N}$, $9 \mathrm{SW}$. In all Scandinavian countries, release cannot be denied to a person who is foreign national and who resides permanently in another country. If a person with

210 Scvig, Nr. 98, 99, 102-104.

Compare sec. 9 Citizenship Act.

(176 F.2d 953, 966 (9th Cir. 1949)

. terms of release. residence inside the country applies for release, the Ministry has a margin of discretion and can for example, require the previous fulfillment of military service obligations. ${ }^{214}$ Art. 42 SWIT is similar, but Switzerland restricts the possibility of release to cases where the national involved lives abroad.

In Germany release is possible, but is not given to (see art. 22(1)):

1. government officials, judges, members of the armed services and other persons appointed to public duties as long as their term of office is not terminated except for volunteers,

2. persons subject to military duty unless the Federal Minister of Defence has declared that he raises no objections against the release. ..

An exception to paragraph 2 is allowed if the person has had permanent residence in a foreign country for at least ten years or has performed mandatory military service in one of the countries of which he is a citizen.

Co has a foreign citizenship may lose the Greek citizenship upon application. In this case the loss of the Greek citizenship occurs from the date that the application is accepted. ${ }^{215}$

Although art. 34(2) of the Polish Constitution mentions that a Polish citizen cannot be deprived of his nationality, but can only renounce it, art. 32 of the bill on Polish nationality which is pending in parliament uses the construction of release. In order to gain relense, a citizen has to lodge a written application to the president, pevidence on: 1) who may render his consent if dochs the acquisition of a foreign nationality or a promise to acquire one; 2) the fulfillmen of fiscal and military duties; 3 ) the fulfillment of obligations resulting from the decision of a court or any other competent authority; 4) the fulfillment of obligation in relation to the "alimony fund of the Social Security Office." 216 Art. 32(3) mentions that the president may refuse to give his consent to renounce Polish nationality, if such refusal is in the interest of the defense and security of the state. In art. 32(4) it is stressed that the renucis is stressed that the renuction may not case sta te foren mationality. It i concerned has already received a promise to acquire a foreign nationality

course, obvious that these conditions do not conform with art. 8 ECN. Art. $21 \mathrm{MOL}$ allows renunciation of Moldovan nationality, but art. $22 \mathrm{MOL}$ provides that the renunciation has to be approved, which leads to the conclusion that it is better to classify this constled up to perform or is currently performing given if the person involved was called up to perform or is curnently peforming

${ }^{4}$ See for Denmark, Torben Steffensen, Danemark, Nr. 37, in: Charles L. Closset/ Michel J. Verwilghen, Paris, loose-leaf edition.

${ }^{115}$ Zoc Papusitition International 1998, 512, 513

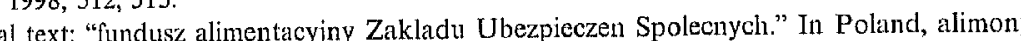
or other related allowances are not paid to the entitled person directly, but through an obligatory fund. Information provided by Marcin Pruss. 
active or alternative military service, provided that this person resides lawfully and habitually in Moldova (art. 22(b) MOL). This condition is in accordance with art. $8 \mathrm{ECN}$. Art. 22(a) MOL makes it possible for release to be granted in order to acquire another nationality.

\section{Difficulty}

The question has to be raised whether renunciation should be possible not only for dual nationals, but also for a mono-national who wants to acquire the nationality of another state, which requires the renunciation as a condition for the grant of nationality by naturalization. In other words: should the Belgian and German nation absolutely no need to do that If state would allow the lodging of a conditional declaration of renunciation (or would give a conditional release of nationality) the same result could be reached, without any period within which the person involved is formally stateless.

\section{Trends}

Rather than giving permission to renounce only in special cases, states generally provide for a general regulation of renunciation. Further, the restriction for persons subject to military service obligations is disappearing gradually (see Belgium; see $\mathrm{ECN}$ ). The same can be observed in respect of the restriction forbidding renunciation by persons against whom criminal procedures are running. It is more realistic to solve possible problems by provisions that grant criminal jurisdiction to a country, inter alia if the person involved had the nationality of that country at the time that inter alla, if the persin in

Many countries still do not permit renunciation in case of residence within the country. Increasingly, countries respect the view of a dual citizen, however, if he wants to renounce the nationality of the state of residence. This is particularly important if the other national state requires its citizens who also possess another nationality to make a choice between their nationalities. ${ }^{21}$

\section{MARRIAGE: NO CONSEQUENCES FOR NATIONALITY}

\section{A. General Remarks: Treaties}

Art. 4(d) ECN provides that neither marriage nor the dissolution of a marriag between a national of a state party and an alien, nor the change of nationality by one of the spouses during marriage, shall automatically affect the nationality of the other spouse. Some elements of this rule could already be found in older conventions.

\footnotetext{
217 See for example, Japan art. 14-16; Luxembourg art. 25(7), and in the past, Italy (art. 5(2) of Act $\mathrm{N}$ 123 of 21 April 1983)
}

Art. 8 of the 1930 Hague Convention:

If the national law of the wife causes her to lose her nationality on marriage with a foreigner, this consequence shall be conditional on her acquiring the nationality of the husband.

Art. 9 of the 1930 Hague Convention:

If the national law of the wife causes her to lose her nationality upon a change in the nationality of her husband occurring during marriage, this consequence shall be conditional on her acquiring her husbands nationality.

Art. 1 of the 1957 Convention on the Nationality of Married Women:

Each Contracting State agrees that neither the celebration nor the dissolution of a marriage between one of its nationals and an alien, nor the change of nationality by the husband during marriage, shall automatically affect the nationality of the wife.

Art. 2 of the 1957 Convention Nationality of Married Women:

Each Contracting State agrees that neither the voluntary acquisition of the nationality of another State nor the renunciation of its nationality by one of its nationals shall prevent the retention of its nationality by the wife of such nationals national.

Art 5(1) of the 1961 Convention on the Reduction of Statelessness

If the law of a Contracting State entails loss of nationality as a consequence of any change in the personal status of a person such as marriage, termination of marriage, legitimation, recognition or adoption, such loss shall be conditional upon possession or acquisition of another nationality.

Art. 6 of the 1961 Convention on the Reduction of Statelessness:

If the law of a Contracting State provides for loss of its nationality by a person's spouse or children as a consequence of that peson losing or being deprived of that nationality, such loss shall be conditional upon their possession or acquisition of another nationality.

B. National Provisions

In the past almost all nationality acts applied the so-called unitary system ${ }^{218}$ of nationality within a family. A foreign woman who married a national generally

218 In French "système unitaire." See Bernard Dutoit, La nationalité de la femme mariée, Band I: Europa (Genf 1973); Band II: Afrique (Genf 1976); Band III: Amérique, Asie, Océanie (Genf 1980) and Bernard Dutoit, Nationalité et mariage: leur interaction dans le droit comparé de la na tionalité, in: Verwilghen, Nationalité, Brussel 1984, 443-474. 
acquired the nationality of her husband. By marrying a foreigner, a woman lost her original nationality. ${ }^{219}$ Therefore, man and wife possessed one and the same nationality, which was, in ius sanguinis countries, also transferred to their children. If a man acquired another nationality during the marriage and therefore lost his original acquinality, his wife (and in most cases their children) also followed this new nationality position.

A disayantage of this system was that in most countries women also used to lose their nationality if they married a stateless person or if their husband became stateless during the marriage. In order to avoid this disadvantage, some states provided that women lost their nationality only if they acquired the nationality of their husbands.220 This policy was encouraged later on by the 1930 Convention on Nationality conThed at The Hague and initiated by the League of Nations. Art. $8 \mathrm{ff}$. of that Convention provided that women would not lose their nationality by or during the Convention provided that women would These provisions were inter alia a reaction marriage if they would become stateless. These provisions were inter alia a reaction to the fact that, after the revolutions of 1918 , the number of stateless persons increased.

Already during the 1920s some countries had made an additional step and given to women an even more independent position by providing that marriage did not influence the nationality of women. The Soviet Union, Bulgaria, and France ${ }^{221}$ were the first the first states to do hy 222

The next step was of course to allow women to transmit their own nationality to The next step was of course to allow women to transmit their own nationality to
all of their children. Before World War II, only the Soviet Union provided for that possibility in all cases. ${ }^{223}$ Since 1927, the French nationality act provided for the transmission of the French nationality of a French mother to all children born on French territory. After World War II, several countries in Eastern Europe also gradually recognized a completely independent position of women in nationality 219 Sec for example around 1900: Austria (par. $32 \mathrm{ABGB}$ ), Belgium (art. $17 \mathrm{sub} 3 \mathrm{Cc}$ ), Denmark, Germany 1892). Spain (art. 22 Cc), Sweden (art. 6 Act 1894), Switzerland, Turkey (compare: art. 7 Act 1869) United Kingdom (sec. 10 sub 1 Act 1870).

220 The first country to do this was (as far as I know) Bulgaria (art. 25; this provision was very liberal no loss ex lege, but marriage was a ground for renunciation on the initiative of the woman involved sec Tratnik, p. 125). See furthermore: France (art. 19), Ittaly (art. 14), Norway, Portugal (art. 22 sub 4); see André Weiss, Traité théorique et pratique de droit international privé, vol. ( Lal nationalité, 2nd edition, Paris 1907, 24. Austrial (since 1925); Denmark (since 1925), Finlind (since 1927), Greece (since 1926), Iceland (oniy loss if residence abroad), Netherlands (since 1937, but with retroactivity to 1893), Norway, Sweden (since 1924), United Kingdom (since 1934

${ }^{221}$ Soviet Union in 1918. Bulgaria: see previous foolnote. Since 1927 until 1938, loss of nationality by French woman marrying a foreigner occurred exclusively if the spouses were living abroad and the nationality of the husband was acquired; since 1938, no longer any loss by marriage.

${ }^{222}$ Austria (since 1947); Betgium (since 1926); Greece (since 1955); Luxembourg (since 1934); Switzerland

223 (since 1941), United Kingdom (since 1934). matters and also allowed the transmission of the nationality to the next generation matters and also allowed the transmission of the nample of the Soviet Union. ${ }^{224}$ under the same conditions as men, following the example of the Soviet Union. An important development was the 1957 Convention on the Nationality of Married Women, which was initiated by the United Nations. This was the first multinational convention aimed to create a completely independent nationality position for married wer her hand by a married countries granted to married women such an independent nationality position and eventually also the possibility to transmit their nationality

nationality position and eventually also the possibility
under the same conditions as men to their children.

A consequence of this development is that almost all countries examined lack provisions dealing with the nationality position of women after the loss of the nationality involved by their husband, because these consequences do not exist.

Nevertheless, in some countries some provisions still deal with the position of Naried women In France art 21-1 underscores that a marriage does not affect the machus or loss of French citizentip. A similar provision can be found in the cquistion or loss of French citizenship. A similar provision che Greek nationality act (art. 4). In Ireland even two provisions deal with this issue.
Sec. 22 IRL provides:

The death of an Irish citizen shall not affect the citizenship of his or her surviving spouse or children.

2. Loss of Irish citizenship by a person shall not of itself affect the citizenship of his or her spouse or children.

Sec. 23 IRL underscores:

A person who marries an alien shall not, merely by virtue of the marriage, cease to be an Irish citizen, whether or not he or she acquires the nationality of the alien.

These provisions can be understood as a reaction to the previous legal situation, but are strictly speaking, superfluous.

In Turkey art. 19 still declares that a Turkish woman who acquires, by her marriage with a foreigner, her husband's nationality loses Turkish nationality if she make of of her husband's nationality. According to Turkish nationality law, a foreign woman of her husband's nationality. According to Tuks nationality by lodging a declaration who marries a Turkish man can acquire Turkish nationality by lodging a deciaration of option. If a woman acquires Turkish nationality in this way, and if the marriage institutions believe that it is not her fault that caused the annulment, then she continues to hold Turkish nationality 22

224 Albania 1946, Bulgaria 1948, German Democratic Republic 1954, Hungary 1957, Yugoslavia 1945, Poland 1951, Romania 1948, Czechoslovakia 1949

225 Information provided by Sadrettin Karahocagyl, Turkish Interior Ministry, The General Directorate of Civil Status and Nationality Issues, Head of Nationality Department. 


\section{Trend}

The trend is obvious. Marriage with a foreigner is gradually disappearing as a
ground for loss of nationality.

\section{LOSS OF A CONDITIONAL NATIONALITY}

In some cases a conditional nationality is acquired. If in such a case the (negtive) condition is fulfilled, the nationality is often lost again. An example of a conditional on German territory in case of bith acquired by some children of foreigners living if these children do not renounce their foreign. This nationality can be lost again between their 18th and 23rd birthe their foreign nationality acquired iure sanguinis above in Part 5.5 Other $\operatorname{coses}$ of a foundling acquires the nationality of a country; or (b) if a person bern observed (a) if a of a country acquires the nationality because otherwise he would on the territory both cases, legislators tend to provide that the nationality acquired in this way is lost again if it is discovered later that the child possesses another nationality.

\section{A. Foundlings}

Art. 6(1)(b) ECN prescribes that a foundling found in the territory of a state has to acquire the nationality of that state if he otherwise would be stateless. The wording of this provision is drawn from art. 1 of the 1961 Convention on the Reduction of infants - in contrast to realize that this provision is not restricted to newbor to every child in the Le, for example, sec. 1(2) British Nationality Act - but applies years unless, under the of the Convention, i.e., every person below the age of 18 inter on, but dun law applicable to the child, majority is attined age of 18 anter on, but during his minority, it is discovered who the parents of thearlier. If and the child derives a nationality from these parents or acquired a child are, because of his place of birth, the nationality pacquirs or acquired a nationality provision may be lost. This is allowed by arity acquired because of the foundling The nationality legislation of the by art. 7(1)(f) ECN.

ECN. Art. 3(2) NL provides of the Netherlands is in conformity with art. 6(1)(b) if he was found on the child of a national Aruba, or on a the Netherlands, the Netherlands Antillesa Anu thus obtains the Netherlands nationality on the basis of art $3(1) N L$. This prese tion (praesumptio itris sanguinis) is not absolute. If it boco(1) NL. This presupposiyears from the day on which the child was found, that becomes apparent, within five nationality, but instead a foreign was found, that he does not possess Netherlands Netherlands will be lost But in the nationality of the nationality.
France (art 19) Moldova (art. 11(2)), Portugal (art. 14), and Switzerland (art. 6(3)) provide that the nationality acquired by a foundling is lost if, during his minority, it is discovered that he is the child of foreign parents, and if he does no thereby become stateless. These provisions correspond precisely with art. $6(1)(b)$ ECN.

In Austria (par. 8(1)), Belgium (art. 10(2)), Denmark (art. 1 (1)), Finland (art. 1), Cermany (par. 4(2)), Greece (cf. art. 1(2)), Iceland (art. 1), Italy (art. 1(2)), Germany (par 4(2)) Geden (art 1) and the Luxembourg (art. 1(2)) Noc. 1(2)), nationality is also lost by a foundling if his descent is United Kingdom (sec. 1(2)), nationality is also lost by
discovered after majority. That conflicts with the ECN.

With respect to art. 6(1)(b) ECN, Austria made a declaration: "Austria declares to retain the right that foundlings found in the territory of the Republic are regarded until proven to the contrary, as nationals by descent only if they are found under the age of six month." It is obvious that this is not a declaration with a interpretive the a convention is meant to cover cases character but a "found" and the circumstances do not allow for the discovery where older chillich are "found and the circumstan of their identification, in particular the descent of the children involved. An early draft version of the European Convention still included a provision on foundlings inspired by the above-mentioned provision of the British Nationality Act, which was restricted to newborn infants. Later the provision on foundlings was revised. The final text is therefore definitely not restricted to very young children. The Austrian reservation is inspired by art. 8(1) of the Austrian Nationality Act.

\section{B. Stateless Children}

According to art. 6(2) ECN, each state party shall provide in its internal law for its Acorre would otherwise be stateless. This rule is repeated in Council of Europe Recommendation R 99 (18) in stateless. This rule is repeated in Country of birth has to be attributed either Part IIA sub b. The nationality of the country of birth has to be attributedication. ex lege at birth or subsequently to children who remained stateless upon application. Of the countries covered in this chapter, Belgium, Canada, Finland, France, Greece, Ireland, Italy, Luxembourg, Mexico, Moldova, Poland, Portugal, Spain, Turkey, and the United States opted for the first mentioned possibility. In most of these cotntries, a provision also can be found dealing with the loss of this

discovered that the person involved was not stateless. ${ }^{226}$

discovered the countries where this ground for acquisition is not linked with a conditional ground for loss. That is, for example, the case in Moldova. Art. 11(2) MOL provides that a foundling found on the territory of Moldova shall be considered as a citizen, unless otherwise proven before the age of 18 . The provision

226 However, in Greece no such provision exists. Information provided by Zoe Papassiopi-Passia in a letterof 16 January 2001 
C. Trend

The trend is obvious. Marriage with a foreigner is gradually disappearing as a ground for loss of nationality.

\section{LOSS OF A CONDITIONAL NATIONALITY}

In some cases a conditional nationality is acquired. If in such a case the (negative) In some con fulfilled, the nationality is often lost again. An example of a conditional nationality is the German nationality acquired by some children of foreigners living on German territory in case of birth in Germany. This nationality can be lost again if these children do not renounce their foreign nationality acquired iure sanguinis between their 18th and 23rd birthday. This legal construction was already described above in Part 5.5.

Other cases of acquisition of a conditional nationality can be observed (a) if a a contry or (b) if a person born on the territory founcling aceuics the nationity or a con of a country acquires the nationality because otherwise he would be stateless. In
both cases, legislators tend to provide that the nationality acquired in this way is both cases, legislators tend to provide that the nationality acquired in this way
lost again if it is discovered later that the child possesses another nationality.

\section{A. Foundlings}

Art 6(1)(b) ECN prescribes that a foundling found in the territory of a state has to Art. 6(1)(b) ECN prestibe that state if he otherwise would be stateless. The wording acquire the nationality of that state if he otherwise would be stateless. The wording
of this provision is drawn from art. 1 of the 1961 Convention on the Reduction of Statelessness. One has to realize that this provision is not restricted to newborn infants - in contrast to, for example, sec. 1(2) British Nationality Act - but applies to every child in the sense of the Convention, i.e., every person below the age of 18 years unless, under the law applicable to the child, majority is attained earlier. If later on but during his minority it is discovered who the parents of the child are, and the child derives a nationality from these parents or acquired a nationality because of his place of birth, the nationality acquired because of the foundiin provision may be lost. This is allowed by art. 7(1)(f) ECN

The nationality legislation of the Netherlands is in conformity with art. $6(1)$ (b) ECN. Art. 3(2) NL provides that a child shall be deemed to be the child of a nationa if he was found on the territory of the Netherlands, the Netherlands Antilles or Aruba, or on a ship or aircraft registered in one of these countries. In this case he Aruba, or on a ship or aircat regiter tion (praesumptio iuris sanguinis) is not absolute. If it becomes apparent, within five years from the day on which the child was found, that he does not possess Netherlands nationality, but instead a foreign nationality by birth, the nationality of the Netherlands will be lost. But in the case of potential statelessness he keeps this nationality.
19), Moldova (art 11(2)), Portugal (art. 14), and Switzerland (art. France (art. 19), Moldova (art. 11(2)), Portugal (art. 14), and lost if, during his 6(3)) provide that the nationality acquired by a foign parents, and if he does not minority, it is discovered that he is the child of fore thereby become stateless. These provisions correspond precisely with art. $6(1)(\mathrm{b})$ ECN.

C. In Austria (par. 8(1)), Breece (cf. art. 1(2)), Iceland (art. 1), Italy (art. 1(2)), Germany (par. 4(2)), Greece (cf. art. S)in (art. 17(d)), Sweden (art. 1), and the Luxembourg (art. 1(2)), Norway (art. 1), Spain (art by a foundling if his descent is United Kingdom (sec. 1(2)), nationality is also the ECN.

discovered after majority. That conflicts with the ECN.

With respect to art. $6(1)$ (b) ECN, Austria made a decla Whe right that foundlings found in the territory of the Republic are reg unde to retain the right the contrary, as nationals by descent only if they are found under until proven to the "It is obvious that this is not a declaration with a interpretive the age of six month." It is The aim of the Convention is meant to cover case character but a reservation. "Th" discovery where older children are "found" and the circunst of the children involved. An early of their identification, in particular the dos and included a provision on foundings draft version of the European Convention still indlestich was inspired by the above-mentioned provision of the British Nationalty inspired to newborn infants. Later the provision on loundlings was reve Thian resticted to very young children. final text is the Austrian Nationality Act.

reservation is inspired by art. 8(1) of the Austrian Nati

\section{B. Stateless Children} According to art. 6(2) ECN, each state party shall proits in is interld otherwise be nationality to be acquired by persons born on its territory who would on $99(18)$ in stateless. This rule is repeated in Council of Europe Recommendation $R$ (t)ibuted either Part IIA sub $b$. The nationality of the country of bined stateless upon application. ex lege at birth or subsequently to children who remand, Finland, France, Greece, Of the countries covered in this chapter, Belgium, Canada, Final, Spain, Turkey, and Ireland, Italy, Luxembourg, Mexico, Moldova, Poland, Portgal, Span, The reland, Italy, Luxember for the first mentioned the United States op thes nationality if it is late a provision also can be fon drued was not stateless. 226

discovered that the person involved where this ground for acquisition is not Nevertheless, there are also counties That is for example, the case in Moldova. linked with a conditional ground for loss. That is, for example, the corritory of Moldovall Art. 11(2) MOL provides that a foundhing found on the provision

nists. Information provided by Zoe Papassiopi-Passia in a However, in Greece no
letterof 16 January 2001. 
of art. 11(1)(b) in favor of potentially stateless children is not qualified in a similar way.

Moreover, in ius soli countries (Canada, Ireland, Mexico, and the United States), the nationality of the country will, of course, not be lost by a national born on the territory because of the fact that another nationality is acquired iure sanguinis.

XII. LOSS OF NATIONALITY BECAUSE OF RECOGNITION OR LEGITIMATION OF A CHILD BY A FOREIGNER

A. General Remarks: Treaties

Art. 16 of the Hague Convention of 1930 provides:

If the law of the State, whose nationality an illegitimate child possesses, recognises that such nationality may be lost as a consequence of a change in the civil status of the child (legitimation, recognition), such loss shall be conditional on the acquisition by the child of the nationality of another State under the law of such State relating to the effect upon nationality of changes in civil status.

Art. 5(2) of the 1961 Convention on the Reduction of Statelessness contains a related provision:

If, under the law of a Contracting State, a child born out of wedlock loses the nationality of that State in consequence of a recognition of affiliation, he shail be given an opportunity to recover that nationality by written application to the appropriate authority, and the conditions governing such application shall not be more rigorous than those laid down in paragraph 2 of Article 1 of this Convention.

Art. 1(2) in turn provides:

A Contracting State may make the grant of its nationality [on application] ... subject to one or more of the following conditions:

(a) that the application is lodged during a period, fixed by the Contracting State, beginning not later than at the age of eighteen years and ending not earlier than at the age of twenty-one years, so, however, that the person concerned shall be allowed at least one year during which he may himself make the application without having to obtain legal authorization to do so:

(b) that the person concerned has habitually resided in the territory of the Contracting State for such period as may be fixed by that State, not exceeding five years immediately preceding the lodging of the application nor ten years in all;

(c) that the person concerned has neither been convicted of an offence against national security nor has been sentenced to imprisonment for a term of five years or more on a criminal charge;

(d) that the person concerned has always been stateless

B. National Provisions

In Part $\mathrm{X}(\mathrm{B})$ of this chapter, it was mentioned that in the past almost all countries applied the so-called unitary system in respect of nationalities in a family. Women followed the nationality of their husbands. Only men could transmit their nationality to the children born in wedlock. In respect of children born out of wedlock, the most common regulation was that these children derived their nationality from their mother, but if (by recognition or legitimation) family relationships also existed with the father, his nationality was decisive. ${ }^{227}$ As a consequence, recognition or legitimation of a child by a foreigner was a ground for loss of the nationality derived from the mother if the recognition or legitimation had as a legal consequence the acquisition of the nationality of the father. ${ }^{228}$

In almost all countries included in this chapter, the equal treatment of men and women and of children born in wedlock or outside wedlock is now realized. As a consequence, most nationality statutes no longer include recognition or legitimation by a foreigner as a ground for loss. ${ }^{229}$

An excention is art $16 \mathrm{NL}$, where it is still provided that a minor shall lose his Netherlands nationality by recognition, legitimation, or adoption by an alien if he thereby acquires the nationality of the alien or already possesses it.

\section{Trend}

The trend is obvious. In a system where the nationality of child can be derived iure sanguinis a matre et a patre, recognition and legitimation should not be maintained any longer as grounds for loss of nationality. This ground for loss conflicts with the equal treatment of men and women and with equal treatment of children born within or out of wedlock.

\section{LOSS OF NATIONALITY; CONCLUSIONS}

Certain grounds for loss of nationality are included in the nationality statutes of several countries, because the countries involved are of the opinion that certain facts indicate that no genuine link between this person and the state continues to exist. This is the case if voluntary acquisition of a foreign nationality is mentioned as a 227 See Gerard-René de Groot, Staatsangehörigkeil, 316-318.

228 Yves Gonset, La nationalité de l'enfant naturel en droit comparé; étude des législations européennes, Geneva 1977

229 For enct Information provided by Zoe Papassiopi-Passia in a letterof 16 January 2001. 
ground for loss and also if permanent residence abroad is a reason for loss of nationality. Of course, one can debate whether voluntary acquisition of a foreign nationality always indicates that the ties with the state of origin are weakened to an extent which legitimates the loss of nationality. Moreover, it is are weakened to an extent which legitimates the loss of nationality. Moreover, it is clear that not every-
body who is living outside the territory of the state of his nationality has lost his body who is living outside the territory of the state of his nationality has lost his ties with his country. But generally speaking, one can conclude that, in order to avoid large numbers of people possessing the nationality of a state without having a genuine link with the state involved, it is advisable either to provide for at least one of these two grounds for loss or to limit the transmission of the nationality in case of birth abroad to the first or the second generation born outside the country. It is noteworthy nevertheless that some states (like Ireland, Italy, and Poland) do not apply at least one of these means to all nationals in order to avoid a transmission of their nationality in perpetuum. Such a perpetuation, after any genuine link has been lost, tends to conffict with the character of the nationality as such.

Of course, many countries also offer a wide possibility of renunciation of the nationality by an individual or release of nationality by the state on application of a person. But that possibility is not enough to avoid the possession of the nationalities involved by persons without serious links to the state involved. Certainly, a renunciation of a nationality gives, under normal circumstances, an indication of the fact that the person involved has the feeling that his links with the state of origin have declined below the threshold of genuineness. Only in very exceptional circumstance will a genuine link continue to exist in spite of renuncintion. is not difficult at all to imagine cases where no link exists anymore, but when, it national does not take the initiative to wenounce, becer of compete but e possesses the nationality inative to renounce, because of complete ignorance that he possesses the nationality involved, laziness, or simply the feeling that one never knows whether the nationality involved could be useful in the future.

In some other cases, the loss of nationality occurs not because the facts involved manifest the loss or inexistence of a genuine link, but - at least partly - as a sanction because of the behavior of the national involved. That is, in my opinion, the case when the nationality is lost because of voluntary military is in of a behavior seriously prejudicial to the vital interests of Nonetheless, some discussion on thr One could some discussion on the character of these grounds for loss is possible. One could argue that the behavior involved illustrates that the person in question lost, or even deliberately cut, the ties with the state of his nationality. But it seems to me that this is not the leading opinion anymore. In this context, one should pay attention to the fact that art. 7 ECN accepts these two grounds of loss, but does not accept any consequences for the nationality of the (still minor) child wen of the person involved. The sins of the parents may not have any consequences for the person The loss of nationality for these reasons immediately imity the immediately imply that these children now lack serious ties with the country involved. This view underscores that the grounds for loss in question are seen as a sanction and not as an indication of the loss of a genuine link.

A particular category is the loss of nationality by revocation of a naturalization decree because of fraud or other similar acts. It is a reaction to the behavior of a decree because of fraud or other similar acts. It is a reaction the acquisition would not person who acquired the nationality by naturalization. If the acquisition would not have taken place absent the fraud, the revocation is based on the conclusion that
the criteria which are used to decide on the naturalization request were not in fact the criteria which are used to decide on the naturalization request were not in fact passed since the acquisition, in the meantime an obvious genuine link between the person involved and the state where the naturalization took place can be developed. The loss of nationality by revocation is then, more or less, a penalty. Art. 7 ECN the loss this ground for loss even in cases where statelessness would be the conaccepts this ground for loss even in cass the children sequence. Loss of nationality and even statelessness is also accepted for the children of the persons involved. This is problematic if the fraud is only discovered after a
very long period and the children were born after the naturalization of the parent who committed the fraud.

A special remark has to be made on the loss of a nationality because of loss of the family relationship which was the basis for the acquisition of a certain nationality. As such, this ground for loss is a logical correction of the grounds of acquisition. If As such, this ground for loss is a logical correction descent of a certain person, it is in principle acceptable that this nationality is again lost if the family relationship in principle acceptable that this nationality is again lost if the family relationship involved is lost. Nevertheless, one has to realize that the person involved can already have developed close factual ties with the state whose nationality he possessed until the family relationship was annulled. It seems to me that it is therefore absolute necessary to limit the period of time during which the person in question is imposed. Art. ECN acceus hesitation whether taking the age of majority as a limit still a minor. I have serious hesitation whether taking the age of mejod of limitation is not considerably too long. Perhaps it would be better to put the period of limitation
at for example, 10 years (the maximum period of residence mentioned in art. 6(3) $\mathrm{ECN}$ in respect of naturalization).

An extremely difficult issue is whether (and if so, under which conditions) grounds for loss should have consequences for the children of those who lose the nationality involved. If the grounds for loss are based on the assumption that the parent does not have ties anymore with the state of the nationality involved, it is an acceptable not have ties any with the state involved. the But again, it is not too difficult to imagine exceptions to this main rule. If the loss of the nationality by a parent has consequences for the children, such exceptional situations have to be regulated as well. On the other hand, it is very problematic to accept that loss of nationality by a parent never has consequences for his minor children if the nationality involved can be transnitted iure sanguinis without any limitation in case of bith abroad Such a regulation would not promote that the nationality of the country involved always gives a serious indication of the existence nationality of the country involved

of a genuine link with the state. A closely related issue is the question of how far parents should be able to influence
the nationality position of their children. If parents lose their nationality because of lack of a genuine link, it can be accepted that their children follow this loss, in 
principle, ex lege. That children lose their nationality when the parents lose this status as a kind of penalty is, on the other hand, not acceptable. But should pase this also be able to represent their children by acts which cause the loss of parents by these children? I have severe hesitations on the cause the loss of nationality protect the interests of their childes. The on this point. Parents have the task to their their children in legal affairs. All jurisdictions provide that, in certain very important matters, parents need the consent of the court in order to be able to represortant

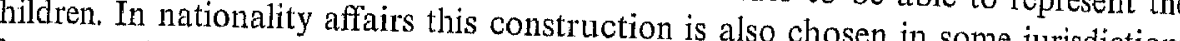
(lor example, Germany). In some other jurisdictions, children cann jusdiction nationality by acts of the parents or even by their own acts commited lose their (for example, Ireland and Mexico). Both views are as minor solution is to provide that a child representative or by his own can reacun the consent of the parent, but that the child can reachine the lost nationality within a certain period after having attained the age of majority. This is an elegant solution, which could also be applied in ex lege loss of nationality by a minor as a consequence of the bes of ationase of a parent.

A special case is the loss of nationality by a child because of the renunciation of this nationality by a parent. It has to be admitted that this can be, under certain circumstances, a manifestation of the loss of a genuine link with the state involved But one has to raise the have such extensive the question whether such a voluntary act by a parent should have such extensive consequences for a child. Limiting such loss by the children to situations where a court has approved would be an acceptable solution. Loss without control and without the possibility of reacquisition after having attained the age of
majority is highly questionable.

\section{TABLES}

Table I

Loss of Nationality because of Voluntary Acquisition of Foreign Nationality

The table also indicates whether and when a country ratified chapter I of the 1963 Convention on the Reduction of Cases of Multiple Nationality, because of the selfexecuting effect of art. 1 , which causes loss of nationality in case of voluntary acquisition of the nationality of another contracting state. Ratifications of the Second Protocol to the 1963 Concentions to art. 1 of the 1963 Convention ratified the allowed.

Austria

Belgium

Canada

Denmark

Denmark

Finland

France

Germany

Greece

Iceland

Ireland

Irelany

Italy

Luxembourg

Mexico

Moldova

Netherlands

Norway

Poland

Portugal

Spain

Sweden

Switzerland

Turkey

United Kingdom

United States loss, with exc. (permission); rat. 1963 conv. in 1975 with reservations

loss, with exc. (military service), rat. 1963 conv. in 1991

no

loss; rat. 1963 conv. in 1972

loss

no; but rat. 1963 conv. in 1965 and 2nd protocol in 1995 loss, with exc. (permission); rat. 1963 conv. in 1969 with reservations (rescinded 1975)

no; but deprivation possible if no permission

loss

no, with exc. (naturalized citizens)

no, with exc. (war) and rat. 1963 conv. in 1968 and 2nd protocol in 1995

loss; rat. 1963 conv. in 1971

no, with exc. (naturalized citizens)

no, but deprivation possible

loss; bill proposes loss with exc. 2nd protocol; rat. 1963 conv. in 1985 and 2nd protocol in 1996

loss

no

no

loss, with many exc. (war, acquisition of specific foreign nationalities)

Until 2002 loss; since 2002 no loss

no

no; but deprivation possible if no permission

no

no 
Table II Grounds for Revocation of Naturalization Decree

\begin{tabular}{|c|c|}
\hline $\begin{array}{l}\text { Austria } \\
\text { Belgium }\end{array}$ & $\begin{array}{l}\text { non-renunciation of other nationality (within } 6 \text { years); fraud } \\
\text { fraud; other }\end{array}$ \\
\hline Canada & fraud \\
\hline Denmark & \\
\hline Finland & \\
\hline France & fraud \\
\hline Germany & fraud \\
\hline Greece & \\
\hline Iceland & \\
\hline Ireland & fraud; other \\
\hline Italy & \\
\hline Luxembourg & fraud; other \\
\hline Mexico & fraud; other \\
\hline Moldova & fraud \\
\hline Netherlands & non-renunciation; under pending bill: fraud (within 12 years) \\
\hline Norway & \\
\hline Poland & fraud (within 10 years) \\
\hline Portugal & \\
\hline Spain & fraud (within 15 years); other \\
\hline Sweden & \\
\hline Switzerland & fraud (within 5 years) \\
\hline Turkey & fraud \\
\hline United Kingdom & fraud; other \\
\hline United States & fraud or illegal acquisition \\
\hline
\end{tabular}

\section{Table III Loss of Nationality Because of Voluntary Foreign Military Service}

Austria

Belgium may be classified as prejudicial behavior

Canada

Denmark

Finland

France

Germany

Greece

Iceland

Ireland

Italy

Luxembourg

Mexico

Moldova

Netherlands

Norway

Poland

Portugal

Spain

Sweden

Switzerland

Turkey

United Kingdom

if prohibition

ex lege (if certain conditions are met)

if prohibition

ex lege (in time of war; otherwise: if prohibition)

may be classified as prejudicial behavior

deprivation possible

no, but bill proposes ex lege (if certain conditions are met)

if prohibition, only for naturalized citizens

if prohibition 
G.-R. de Groot

Table IV Loss of Nationality Because of Serious Prejudicial Behavior

Austria acts against national interest in service of foreign state

Belgium naturalized citizens: neglect of duties as citizen

Canada

Denmark

Finland

France

Germany

Greece

Iceland

Ireland

Italy

Luxembourg

Mexico

Moldova

Netherlands

Norway
Poland

Portugal

Spain

Sweden

Switzerland

Turkey

United Kingdom

United States behavior as foreigner; naturalized citizens: crimes

no

acts against national interest

no

naturalized citizens: disloyalty

no

naturalized citizens: neglect of duties as citizen; behavior as foreigner; crimes

naturalized citizens: accepting foreign noble titles

acts against vital interests of the state

no

no

naturalized citizens: crimes

acts against national interest or reputation

desertion from army; naturalized citizens: staying abroad desertion from

naturalized citizens: disloyalty; collaboration with enemy; crimes

treason; levying war against nation (requires specific intent to

relinquish citizenship)
Table V Loss of Nationality Because of Lack of Genuine Link

(The countries of which the names are printed in bold have rules on the limitation of the transmission of their nationality in case of birth abroad.)

Austria

Belgium

Canada

Denmark

Finland

France

Germany

Greece

Iceland

Ireland

Italy

Luxembourg

Mexico

Moldova

Netherlands

Norway

Poland

Portugal

Spain

Sweden

Switzerland

Turkey

United Kingdom

United States yes; declaration of continuation possible

yes; declaration of continuation is, under conditions, possible

yes; permission of retention possible

yes, permission of retention possible

yes; deprivation procedure

yes; permission of retention possible

naturalized citizens: deprivation procedure

natur

yes; declaration of continuation possible

naturalized citizens

yes; bill makes continuation possible

yes; permission of retention possible

no

yes; if exclusive use of other nationality

yes; permission for retention possible

yes; deprivation procedure 
Table VI Loss of Nationality Because of Loss of Family Relationship

$\begin{array}{ll}\text { Austria } & \text { yes } \\ \text { Belgium } & \text { yes: art. 8(4) } \\ \text { Canada } & \\ \text { Denmark } & \\ \text { Finland } & \text { yes, art. 20-1 Cc } \\ \text { France } & \\ \text { Germany } & \\ \text { Greece } & \\ \text { Iceland } & \\ \text { Ireland } & \\ \text { Italy } & \text { yes; see art. 3(3), loss because of revocation of adoption } \\ \text { Luxembourg } & \text { decree } \\ \text { Mexico } & \text { yes: art. 25(5) } \\ \text { Moldova } & \text { yes: art. 14, loss because of revocation of adoption decree } \\ \text { Netherlands } & \text { yes: art. 14(1) } \\ \text { Norway } & \\ \text { Portugal } & \\ \text { Spain } & \\ \text { Sweden } & \text { yes: no provision } \\ \text { Switzerland } & \text { yes: art. } 8 \\ \text { Turkey } & \text { yes } \\ \text { United Kingdom } & \\ \text { United States } & \end{array}$

\section{Table VII Loss of Nationality Because of Adoption by Foreign Parents}

Austria

Belgium

Canada

Denmark

Finland

France

Germany yes: art. 27

Greece

Iceland

Ireland

Italy

Luxembourg

Mexico

Moldova

Netherlands

Norway

Poland

Portugal

Spain

Sweden

Switzerland

Turkey

United Kingdom

United States

yes: art. $22(1)(4)$

yes: art. $27(2)$, after decision of the Minister of Interior

yes: art. 24(4)

no: art. $30(1)$ Ley de nacionalidad

no

yes: art. 16(1)(a)

yes: art. $8 \mathrm{a}(1)$

no 
Table VIII Loss of Nationality for Children When Parents Lose Nationality

$\begin{array}{ll}\begin{array}{l}\text { Austria } \\ \text { Belgium }\end{array} & \text { often } \\ \text { Canada } & \text { often } \\ \text { Denmark } & \text { often } \\ \text { Finland } & \text { often } \\ \text { France } & \\ \text { Germany } & \text { sometimes } \\ \text { Greece } & \\ \text { Iceland } & \text { often } \\ \text { Ireland } & \text { no: sec. 22(2) } \\ \text { Italy } & \\ \text { Luxembourg } & \text { often } \\ \text { Mexico } & \text { no: art. 29 Ley de nacionalidad } \\ \text { Moldova } & \text { deprivation: no (art. 23(3)); renunciation: sometimes (cf. art. } \\ & \text { 37) } \\ \text { Netherlands } & \text { often } \\ \text { Norway } & \text { often } \\ \text { Portugal } & \text { sometimes } \\ \text { Spain } & \\ \text { Sweden } & \text { often } \\ \text { Switzerland } & \text { often } \\ \text { Turkey } & \\ \text { United Kingdom } & \\ \text { United States } & \end{array}$

Table IX Renunciation of Nationality

$\begin{array}{ll}\text { Austria } & \begin{array}{l}\text { under conditions if residence abroad; in exceptional cases in } \\ \text { country } \\ \text { yes } \\ \text { Belgium }\end{array} \\ \begin{array}{l}\text { release, if residence abroad; in exceptional cases also in } \\ \text { country } \\ \text { release }\end{array} \\ \text { Denmark } & \text { release } \\ \text { Finland } & \text { only in listed cases } \\ \text { France } & \text { release, under conditions } \\ \text { Germany } & \text { release, under conditions } \\ \text { Greece } & \text { release } \\ \text { Iceland } & \text { if residence abroad (not in war time) } \\ \text { Ireland } & \text { if residence abroad; in exceptional cases also in country } \\ \text { Italy } & \text { yes } \\ \text { Luxembourg } & \text { release, under conditions } \\ \text { Mexico } & \text { yes } \\ \text { Moldova } & \text { release } \\ \text { Netherlands } & \text { yes } \\ \text { Norway } & \text { only in listed cases } \\ \text { Portugal } & \text { release } \\ \text { Spain } & \text { release, if residence abroad } \\ \text { Sweden } & \\ \text { Switzerland } & \text { yes (not in war time) } \\ \text { Turkey } & \text { yes } \\ \text { United Kingdom } & \\ \text { United States } & \end{array}$


Table X Loss of Nationality Upon Recognition/Legitimation of Child by Foreign

Father.

Austria
Belgium
Canada

Denmark

Finland

France

Germany

Greece

Iceland

Ireland

Italy

Luxembourg

Mexico

Netherland

Norway

yes: art. 16(1)(a)

Poland

Portugal

Spain

Sweden

Switzerland

Turkey

United Kingdom

United States
Table XI Loss of Nationality by Foundling, if Descent is Discovered

Austria yes: par. $8(1)$

Belgium yes: art. 10(2)

Canada no (ius soli)

yes: art. 1(2)

Finland $\quad$ yes: art. 1(2)

France yes: art. 19: during minority

Germany $\quad$ yes: par. $4(2)$

Greece of. art. 1(2)

yes: art. 1(2)

yes: sec. 10 (deemed to be born in Ireland) (ius soli)

Italy yes: art. 1(2)

Luxembourg yes: art. 2

Mexico no (ius soli)

Moldova $\quad$ yes: art. 11(2): during minority

Netherlands yes: art. 3(2): within 5 years

Norway yes: art. 1(2)

Poland cf. art. 11

Portugal yes: art. 14: during minority

Spain

art. $17(\mathrm{~d})$

$\begin{array}{ll}\text { Sweden } & \text { yes: art. 1(2) } \\ \text { Switzerland } & \text { yes: art. 6(3): during minority }\end{array}$

Turkey art. 4(2)

United Kingdom yes: sec. 1(2)

United States no (ius soli) 
Table XII Loss of Nationality for Stateless Persons Born on Territory, if Nationality is Discovered

(The names of states that attribute their nationality to stateless children born on the territory are printed in bold. If a state applies generally the principle of acquisition of nationality iure soli, this is mentioned.

$\begin{array}{ll}\begin{array}{l}\text { Austria } \\ \text { Belgium }\end{array} & \\ \text { Canada } & \text { yes: during minority } \\ \text { Denmark } & \text { no (ius soli) } \\ \text { Finland } & \\ \text { France } & \\ \text { Germany } & \\ \text { Greece } & \\ \text { Iceland } & \text { yes } \\ \text { Ireland } & \text { no (ius soli) } \\ \text { Italy } & \\ \text { Luxembourg } & \\ \text { Mexico } & \text { no (ius soli) } \\ \text { Moldova } & \text { no } \\ \text { Netherlands } & \\ \text { Norway } \\ \text { Poland } & \\ \text { Portugal } & \text { no } \\ \text { Spain } & \\ \text { Sweden } & \\ \text { Switzerland } & \\ \text { Turkey } & \\ \text { United Kingdom } & \\ \text { United States } & \text { no (ius soli) }\end{array}$

Austria

Belgium

Canada

Denmark

Finland

France

Germany

Greece

Iceland

Ireland

Luxembourg

Mexico

\section{ANNEX}

List of Nationality Statutes

Staatsbürgerschaftsgesetz 1965, Act of 15. July 1965 , Bundesgesetzblatt 1965, 68. Stück vom 11. August 1965, p. $1171, \mathrm{Nr} .250$, most recently amended by

Staatsbürgerschaftsnovelle 1998, Bundesgesetzblatt I, Nr 124/1998, in force on 1 January 1999

Code de la nationalité belge/ Wetboek van de Belgische nationaliteit, Act of 28 June 1984, Moniteur belge/Belgisch Staatsblad, 12 July 1984 , p. 10.095-10.114, most recently amended by Act of 1 March 2000, Moniteur belge/Belgisch Staatsblad 6 April 2000, in force on 1 May 2000

Act respecting Canadian citizenship, Act C-20 of 13 April 1976

Lov om dansk infodsret, Act Nr. 352 of 27 May 1950, Lov Tidende of 14 June 1950, most recently amended by Act $\mathrm{Nr}$. 1102 of 29 December 1999

1102 of 29 December 1999 1968, Finlands Författningssamling Act Nr. $401 / 68$ of 28 June 1968, Finlands Förattningssamling 1968, Nr. 401, p. 963 , most recently amended by Act $482 / 1$
in force since 15 August 1998

Code civil, art. 17-33-2, most recently amended by Act 99-1141 of 29 December 1999, Journal Officiel Nr. 302 December 1999

Decenor 1999, Bundesgesetzblatt I 1999, p. 1618-1624

(Act on Greek Nationality), Act. Nr 3370/1955, Ephemeris tes Kyberneseos, Nr. 258 of 23 September 1955, most recently amended by Act 2623/1998, in force on 25 June 1998; Act 2647/1998 and Act 2790/2000

L̈g um Íslenskan Ríkisborgararétt, Act Nr. 100 of 23 December 1952, most recently amended by Act $\mathrm{Nr} 82$ of 16 June 1998

Irish Nationality and Citizenship Act, Act Nr. 26 of 17 July

1956, Acts of the Oireachtas 1956 , p. 439, most recently

amended by the Irish Nationality and Citizenship Act 1994 Legge sulla cittadinanza italiana, Act Nr. 91 of 5 February 1992, Gazetta Ufficiale 15 February 1992, Nr. 38

Loi sur la nationalité luxembourgeoise, Act of 22 February 1968 Mém 1968, 91: Texte coordinée 11 December 1986. Mém. 1986, 2354

Ley de nacionalidad, Act of 23 January 1998; see also Constitución politica art. 32-37 
Moldova

Netherlands

Legea Ce_ateniei Republicii Moldova, Act of 2 June 2000, Monitorul Oficial Nr 98-101 709 of 10 A Rijkswet op het Nederlandersc Staatsblad 1984, 627. This Act is most Act of 21 1984, 627. This Act is most recently amended by Act of 21 December 2000, Staatslad 2000, 618 which will come in force in the end of the year 2000 or the beginning of 2003; see also Bill 28309 (R 1702) pending in parliament which proposes to amend again both the Act of 1984 and Act of 2000.

Norway

Tidende Nr: 49 Riksborgarrett, Act of 8 December 1950, Lov by Act Nr. 49 of 19 December 1950, most recently amended by Act of 11 June 1999, Nr, 38, in ofrce since 1 December
1999

Poland

Ustawa o obywatelstwie polskim, Act of 15 February 1962 Rzeczypospolitej Polskiej 1962 Nr. 10 February 1962, pos. 49

Portugal

Lei da Nacionalidade português, Act 37/81 of 3 October 1981, amended by Legislative serie, Nr. 228, p. 2648 , most recently Art. 17-26 Códico civil, Decree Nr 37 of 31 January 1997 Art. 17-26 Codigo civil, as amended by Act 18/1990 of 17 December 1990, Boletin Oficial del Estado, Nr. 3 of 18 November 1995 , most recently amended by Act 29/95 of 2 November 1995

Sweden

Lag om Svenskt Medborgarskap, Act Nr. 382 of 22 June 1950, Svensks Författningssamling of 30 June 1950 , p. 717 amended by Act 29/1995 of 2 Novo amended by Act of 26 November 1998 See om svenskt medbor 26 Novenber 1998. See also the new Lag om svenskt medborgarskap, Act. Nr. 82 of 1 March 2001, in Bundesgestz 1001

Bundesgesetz ü Erwerb und Verlust des

Schweizerbutrgerrechts, Bundesblatt 1952 III, 137, most

recently amended by Act of 24 March 2000, in force since 1 September 2000

Turkey

22 February 1964 February 1964, Resmî Gazete Nr. 11638 of

7 June 1995 , Ret

United Kingdom United States

British Nationality Act 198

Immigration and Nationality Act, Act of 27 June 1952, Pub.

82-414, 66 Stat. 163, as amended, codified ine 1952, Pub. $1101 \mathrm{ff}$.

\section{ANNEX II}

Treaties and Recommendations in the Field of Nationality Law

Treaties

These nationality statutes are included in this project (Only those con are mentioned. Moreover only those with an asterisk.)

CONVENTION ON CERTAIN QUESTIONS RELATING TO THE CONFLICT OF NATIONALITY LAWS of The Hague 12-4-1930 (UNTS Col 179,89

Contracting Parties i.a.: Belgium," (Canada; denunciation on 15 May 1996) Netherlands, * Norway, Poland, Sweden,* United Kingdom

Belgium made following declaration: "Conformément aux dispositions de l'article 20 de la convention, la ratification de la Belgique est donnée à l'exclusion de "l'article 16 de celle-ci". Nevertheless this declaration no longer has relevance for contemporary Belgian nationality law.

The Netherlands made the following reservation: "Les Pays-Bas: Excluent de The Netheration les articles 8,9 et $10 ;. . . "$ Nevertheless this reservation no longer leur acceptation fos contemporary Netherlands nationality law.

has relevance for contemportion of the second sentence of art. 11, in case where Sweden excluded the application of the secovering the nationality of her country

the wife referred to in the article, after recovering the nation country.

2. PROTOCOL REIATING TO A CERTAIN CASE OF STATELESSNESS. The Hague 1930 (UNTS vol. 179, 115)

Contracting Parties i.a.: Netherlands, Poland, United Kingdom

3. PROTOCOL RELATING TO MILITARY OBLIGATIONS IN CERTAIN PROTOCOL RELATN NATIONALITY. The Hague 1930 (UNTS vol. 178, 227) CASES OF DOUBLE NATIONALTY. United Contracting Parties i. Kingdom, United States

CONVENTION RELATING TO THE STATUS OF REFUGEES (art. 34, Naturalization), Geneva 28 July 1951 (UNTS vol. 189, 137)

Contracting Parties i.a.: Austria, Belgium, Canada, Denmark, Finland, France, Germany, Greece, Iceland, Ireland, Italy, Luxembourg, Netherlands, Norway, 
5. CONVENTION RELATING TO THE STATUS OF STATELESS PERSONS (art. 32; Naturalization), New York 28 September 1954 (UNTS vol 360,11) Contracting Parties i.a.:Austria, Belgium, Denmark, Finland, France Germant Greece, Ireland, Italy, Luxembourg, Netherlands, Norway, Spain, Sweden,
Switzerland, United Kingdom

6. CONVENTION ON THE NATIONALITY OF MARRIED WOMEN, New York 20 February 1957 (UNTS vol. 309, 65)

Contracting Parties i.a.: Austria, Canada, Denmark, Finland, Germany, Iceland, Ireland, Luxembourg, Mexico, (until 16 January 1973 Netherlands), Norway,
Poland, Sweden, (until 24 December 1982, United Kingdom) NATIONALITY, belonging to the CONCERNING ACQUISITION OF 18 April 1961 (UNTS vol. 500, 223)

Contracting Parties i.a.: Belgium, Denmark, Finland, Germany, Iceland, Italy, Netherlands, Norway, Sweden, Switzerland

8. CONVENTION ON THE REDUCTION OF STATELESSNESS, NEW YOA 30 August 1961 (UNTS 989, 175)

Contracting Parties i.a.: Austria,* Canada, Denmark, Germany,* Ieland, Netherlands, Norway, Sweden, United Kingdom* Austria made following declarations regarding art. 8(

declares to retain the right to deprive a perding art. 8(3)(a)(i) and (ii): "Austria enters, on his own free will, deprive a person of his nationality, if such person declares to retain the right to the military service of a foreign state: "Austria being in the tain the right to deprive a person of his nationality, if such person prejudicial to the interest foreign State, conducts himself in a manner seriously Germany made following dectic

apply the said Convention: in retion: "The Federal Republic of Germany will who are stateless under the relating to the Status of Staterestaph 1, of the Convention prevention of statelessess and 28 September 1954; in respect of within the of statessness and retention of nationality, to German nation within the Germany."

Ireland declared: "In accordance with paragraph 3 of article 8 of the Convention Ireland retains the right to deprive a naturalised Irish citizen of his Convention pursuant to section 19 (1)(b) of the Irish Nationality ar on grounds specified in the aforesaid paragraph."
The United Kingdom declared in accordance with art. 8(3): “... that, notwithstanding the provisions of paragraph 1 of article 8 , the United Kingdom retains the right to deprive a naturalised person of his nationality on the following the right to deprive a naturalised person of his nationality on the following
grounds, being grounds existing in United Kingdom law at the present time: that, inconsistently with his duty of loyalty to Her Britannic Majesty, the person has, in disregard of an express prohibition of Her Britannic Majesty, rendered or continued to render services to, or received or continued to receive emoluments from another State, or has conducted himself in a manner seriously prejudicial to the vital interests of Her Britannic Majesty."

9. OPTIONAL PROTOCOL CONCERNING ACQUISITION OF NATIONALITY, belonging to the Convention of Consular Relations, Vienna 24 April 1963 (UNTS vol. 596, 469); in force for Contracting Parties i.a.: Belgium, Denmark, Finland, Germany, Iceland, Italy, Netherlands, Norway, Sweden, Switzerland

10. CONVENTION ON REDUCTION OF CASES OF MULTIPLE NATIONALITY AND MILITARY OBLIGATIONS IN CASES OF MULTIPLE NATIONALITY, Strasbourg 6 May 1963 (UNTS vol. 634, 221)

Contracting States: Austria, ${ }^{*}$ Belgium, Denmark, France, Germany, ${ }^{*}$ Ireland,* Italy, ${ }^{*}$ Luxembourg, Netherlands, Norway, Spain, ${ }^{*}$ Sweden (until 2002), United Kingdom*

Austria made following declarations:

"1. La République d'Autriche fait usage de la réserve prévue au point de l'Annexe à la Convention;"

“2. A l'occasion du dépôt de l'instrument de ratification de la présente Convention effectué aujourd'hui, la République d'Autriche déclare que les expressions, obligations militaires/military obligations' employées aux articles 5 et 6 seront interprétées, de façon que l'on n'entend par là que l'obligation de l'individu d'accomplir son service militaire. D'autres obligations militaires se sont en rien affectées par la présente Convention."

Germany made a reservation and a declaration: "1. La Republique Fédérale d 'Allemagne fait usage des réserves prévues aux Nos. 1 et 3 de l'Annexe à la Convention; 2. La Convention du 6 Mai 1963 sur la réduction des cas de pluralité de nationalités et sur les obligation militaires en cas de pluralité de nationalités de nationalités et sur les obligation militaires en cas de pluralité de nationalités
s'appliquera également au Land Berlin avec effet de la date à laquelle elle entrera en vigueur pour la République Fédérale d'Allemagne. Vu le fait qu'aucune obligation militaire n'existe à Berlin, les dispositions du Chapitre II de la Convention n'y sont pas applicables."

The reservation mentioned in Nr. 1 of the Annex was taken back by Germany from 1 January 1975. The reservation mentioned in Nr. 3 does still apply. 

Ireland ratified only the second chapter of the treaty and is not bound by the
nationality provisions.

Italy made the following reservations: "Le Gouvenement réserves 1,2 et 4 figurant à l'Annes à Gouvernement italien fait usage des réserve: de subordonner la per annexe à la Convention et, en conséquence, et 3 de l'article ler à con perte de sationalité prévue aux pararaphes 1,2

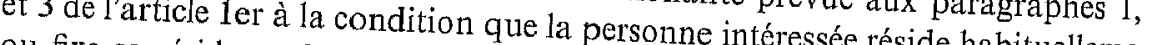
ou fixe sa residence habituelle à quelque moment que se soit en debituellemen territoire, à moins que, 's'agissant d'une acquisition par soit en dehors de son de volonté, la même personne soit dispensé par par manifestation expresse condition de résider habituellement à l'étrane par l'autorité compétente de la une option au sens de l'article ler, a letranger; de ne pas considérer comme d'acquérir la nationalité du ler la declaration souscrite par la femme en vue appliquer les dispositions du au moment et par l'effet du mariage; de ne pas l'épouse de l'un desition ses ressortissants a acquis une nouvelle nationalite, longtemps que son mari conserve la nationalité de nouvelle nationalité, aussi Spain ratified only the second chapter

nationality provisions. The United Kingdom ratified only the Second chapter of the Treaty and is not
bound by the nationality provisions.

11. PROTOCOL AMENDING THE CONVENTION ON REDUCTION OF CASES OF MULTIPLE NATIONALITY AND MILITARY OBLION O IN CASES OF MULTIPLE NATIONALTTY MILITARY OBLIGATIONS Strasbourg 24 November 1977 (ETS 95)

Contracting States:

Spain, Sweden (until 2002), Denmark, Luxembourg, Netherlands, Norway,

OF CASES OF TOCOL TO THE CONVENTION ON REDUCTION OBLIGATIONS IN CASES OF MULTIIONALITY AND MILITARY May 1963), Strasbourg 24 Novemer 1977 (ETS 96 ) NALITY (Strasbourg 6 Con

Contracting States: Belgium, Luxembourg, Netherlands, Norway

13. SECOND PROTOCOL AMENDING THE CONVENTION ON THE REDUCTION OF CASES OF MULTIPLE NATIONALITY THE MILITARY OBLIGATIONS IN CASES OFPLE NATIONALITY AND Strasbourg 1993
ConIGIONS IN CASES OF MULTIPLE NATIONALITY,

Contracting States: France, Italy, Netherlands

14. CONVENTION ON THE EXCHANGE OF INFORMATION REGARDING 296
ACQUISITION OF NATIONALITY (CONVENTION CONCERNANT L'ÉCHANGE D'INFORMATION EN MATIĖRE D'ACQUISITION DE NATIONALITÉ), Paris 10 September 1964 (UNTS 932, 81)

Contracting States: Austria, Belgium, Greece, Italy, Luxembourg, Netherlands, Portugal, Turkey

15. INTERNATIONAL CONVENTION ON THE ELIMINATION OF ALL FORMS OF RACIAL DISCRIMINATION, New York 7 March 1966 (art. 5(d)(iii)) (UNTS 660, 195)

Contracting States i.a.: Austria, Belgium, Canada, Denmark, Finland, France, Germany, Greece, Iceland, Ireland, Italy, Luxembourg, Mexico, Netherlands, Norway, Poland, Portugal, Spain, Sweden, Switzerland, Turkey, United Kingdom, United States of America

16. INTERNATIONAL COVENANT ON CIVIL AND POLITICAL RIGHTS, New York 19 December 1966 (art. 24) (UNTS 999, 172)

Contracting States i.a.: Austria, Belgium, Canada, Denmark, Finland, France, Germany, Greece, Iceland, Ireland, Italy, Luxembourg, Mexico, Netherlands, Norway, Poland, Portugal, Spain, Sweden, Switzerland, Turkey, United Kingdom, United States of America

17. EUROPEAN CONVENTION ON THE ADOPTION OF CHILDREN (art. 11), Strasbourg 24 April 1967 (UNTS 634, 255; ETS 58)

Contracting States i.a.: Austria, Denmark, Germany, Greece, Ireland, Italy, Norway, Poland, Portugal, Sweden, Switzerland, United Kingdom

18. CONVENTION ON THE REDUCTION OF CASES OF STATELESSNESS (CONVENTION TENDANT À RÉDUIRE LE NOMBRE DES CAS D'APATRIDIE), Berne 13 September 1973

Contracting States: Germany, Greece, Luxembourg, Netherlands (denunciation in 2001), Switzerland, Turkey

19. INTERNATIONAL CONVENTION ON THE ELIMINATION OF ALL FORMS OF DISCRIMINATION OF WOMEN, New York 18 December 1979 (art. 9) (UNTS 660, 195)

Contracting States i.a.: Austria, Belgium, Canada, Denmark, Finland, France, Germany, Greece, Iceland, Ireland, Italy, Luxembourg, Mexico, Netherlands, Norway, Poland, Portugal, Spain, Sweden, Switzerland, Turkey,* United Kingdom*

Turkey declared: "Article 9, paragraph 1 of the Convention is not in conflict 
with the provisions of article 5, paragraph 1, and article 15 and 17 of the Turkish Law on Nationality, relating to the acquisition of citizenship, since the intent of those provisions regulating acquisition of citizenship through marriage is to prevent statelessness."

The United Kingdom declared: "The British nationality Act 1981, which was brought into force with effect from January 1983, is based on principles which do not allow of any discrimination against women within the meaning of Article 1 as regards acquisition, change or retention of their nationality or as regard the nationality of their children. The United Kingdom's acceptance of Article shall not however, be taken to invalidate the continuation of certain of Article or transitional provisions which will continue in force beyond that temporary

20. CONVENTION ON THE RIGHTS OF THE CHILD, New York 20 Novem 1989 (art. 7 and 8) (UNTS 1577, 3)

Contracting States i.a.: Austria, Belgium, Canada, Denmark, Fintand, Fance, Germany, Greece, Iceland, Ireland, Italy, Cinada, Denmark, Finland, France, Norway, Poland, Portugal Kingdom 21. EUROPEAN CONVENTION ON NATIONALITY, Strasbourg 6 November
1997 (ETS 166)

Contracting States i.a.: Austria,* Moldova, Netherlands*, Portugal, Sweeden The relevant reservations/declarations made by Austria and the Nethelands are
described in the test of this described in the test of this chapter.

22. CIEC CONVENTION CONCERNING THE DELIVERY OF A
CERTIFICATE OF NATIONALITY, Lisbon 14 September 1999 not yet in force

Declarations, Resolutions, and Recommendations of International Organizations

23. UNIVERSAL DECLARATION OF HUMAN RIGHTS (art. 15) (Adopted and proclaimed by General Assembly of the United Nations, resolution 217A (III)
of 10 December 1948)

24. RECOMMENDATION 194 (1959) ON THE NATIONALITY OF CHILDREN OF STATELESS PERSONS (Council of Europe)

25. RECOMMENDATION 519 (1968) ON THE NATIONALITY OF MARRIED WOMEN (Council of Europe)

26. RECOMMENDATION 564 (1969) ON THE ACQUISITION BY REFUGEES
OF THE NATIONALITY OF THEIR COUNTRY OF RESIDENCE (Council of Europe)

27. RESOLUTION (70)2 ACQUISITION BY REFUGEES OF THE NATIONALITY OF THEIR COUNTRY OF RESIDENCE (Council of Europe)

28. RECOMMENDATION 696 (1973) ON CERTAIN ASPECTS OF THE ACQUISITION OF NATIONALITY (Council of Europe)

29. RESOLUTION (77)12 ON THE NATIONALITY OF SPOUSES OF DIFFERENT NATIONALITIES (Council of Europe)

30. RESOLUTION (77)13 ON THE NATIONALITY OF CHILDREN BORN IN WEDLOCK (Council of Europe)

31. RECOMMENDATION 841 (1978) ON SECOND GENERATION MIGRANTS (Council of Europe)

32. RECOMMENDATION No.R (83)1 ON STATELESS NOMADS AND NOMADS OF UNDETERMINED NATIONALITY (Council of Europe)

33. RECOMMENDATION No. R (84)9 ON SECOND GENERATION MIGRANTS (Council of Europe)

34. RECOMMENDATION 984 (1984) ON THE ACQUISITION BY REFUGEES OF THE NATIONALITY OF THE RECEIVING COUNTRY (Council of Europe)

35. RECOMMENDATION No. R (84)21 ON THE ACQUISITION BY REFUGEES OF THE NATIONALITY OF THE HOST COUNTRY (Council of Europe)

36. RECOMMENDATION No. R (99)18 ON THE AVOIDANCE AND THE REDUCTION OF STATELESSNESS (Council of Europe) 